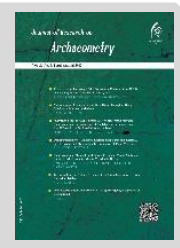

\title{
Compositional study of the Potteries from Sarcham, Bardemar and Kenacheh Sites, Hawraman Area, Kurdistan Province, Iran
}

\author{
Amir Saed Mucheshi ${ }^{\star 1}$, Amir Esna-Ashari ${ }^{2}$, Seyyed Morteza Rahmati ${ }^{3}$, Roya Bahadori ${ }^{4}$, \\ Farah Sadat Madani ${ }^{5}$ \\ ${ }^{1}$ Department of art and architecture, Payame Noor University (PNU), PO Box 19395-3697, Tehran, IRAN \\ ${ }^{2}$ Department of Geology, Payame Noor University (PNU), PO Box 19395-3697, Tehran, IRAN \\ ${ }^{3}$ Dirin Pazhohesh Parine Co. Ltd., Tehran, IRAN \\ ${ }^{4}$ Assistant professor, Research institute of cultural heritage \& tourism, Tehran, IRAN \\ ${ }^{5}$ M.A. in conservation of cultural properties, Research center for conservation of cultural relics, Tehran,
} IRAN

The archaeological sites, including the Sarcham, Bardemar and Kenacheh were excavated during the Darian Dam Archaeological Salvage Project (DDASP) in the Hawraman region, west of the Kurdistan province, western Iran. These sites are adjacent to the Sirwan River. Bardemar is an open-air site and Kenacheh is a cave site. Both sites contain the material cultures of the late Islamic period with simple brown potteries. Mica was the temper which used for making the potteries, so their tempers are shiny and reflect easily the light. The potteries of these two sites were hand-made and not well-fired. The Sarcham is a multi-period site and was recognized the records of Parthian/Sassanid period, Iron Age I, late Bronze Age and Chalcolithic period. The historical period potteries are mostly orange and wheel-made. While, the Iron Age I potteries are divided to buff, orange and grey colors. The grey wares are less abundant. These potteries that have temper were mostly hand-made and under-fired. The same characteristic can be seen in those of the Bronze Age. Potteries related to the Chalcolithic period are categorized into two groups of red slipped and the buff wares. The latter ones that are occasionally characterized by black-on-buff decoration are in minority. During this period the straw-temper was mostly used for tempering the potteries, where they were mostly under-fired. Totally 42 potsherds were selected for X-ray diffraction (XRD) and X-ray fluorescence (XRF) analysis including 14 samples from Bardeh Mar, 8 samples from Kenacheh and 20 samples from Sarcham. Some factors that could help to better characterize the soils, including variety of sites in which the potteries are found, their uses and the pottery styles, were used to provenance the potteries of this study. In addition to the data of the potteries, data of three soil samples surrounding the excavated sites were generated. The XRD data showed that calcite, quartz, clay minerals, feldspar and iron oxides are the main pottery-forming minerals, while the calcite, quartz and clay minerals are the main soil-forming minerals. The XRD data suggests derivation of few potteries from non-local materials. However, the XRF data from the potteries revealed that all the samples are cogenetic and originated from the soils of the same geological formation. All the excavated sites are located on the same rock types or the alluvium derived from them. The rocks and consequently the derived alluvium (soils) were formed as the result of the same geological process (es). This is the evidence confirming the results obtained by

*Corresponding author: saedmucheshi@gmail.com 
the XRF data. The XRD and XRF data that are compiled with the geological information of the area where the sites are located indicates that all the potteries of different periods have similar characteristics and made by the use of local materials. All the potteries from Chalcolithic period to the late Islamic period, even the ones with lower frequencies, were made using the local soils. The results are also applicable for the Kenacheh cave, where it has been used by the local transhumances. Location of the Hawraman region in a mountainous area, adjacent to the westcentral Zagros and Mesopotamia has caused that the way of living of the ancient people of this area be always questionable. Recognition of the soils that had been the origin of the potteries is helpful for characterization of the geographical origin of the potteries.

Keywords: Chemical Analysis, Pottery, Mineralogy, Hawraman, XRD, XRF 


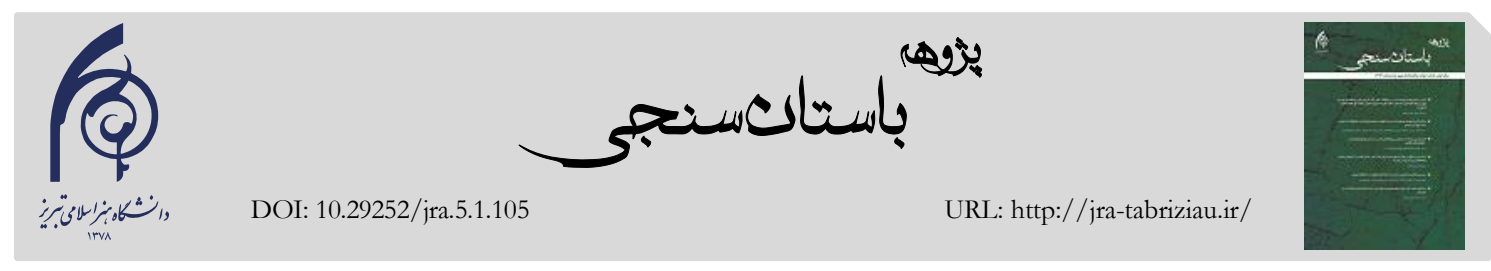

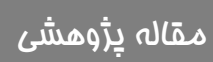

\title{
$\bigodot_{\text {CrossMark }}$ (محوطههاي سرجهم، بردهمار و كناجه)

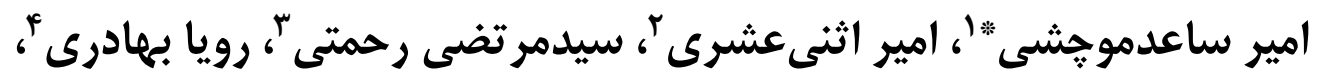

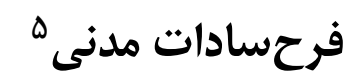

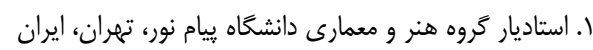

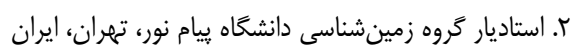

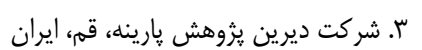

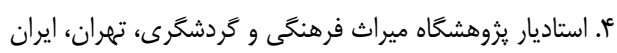

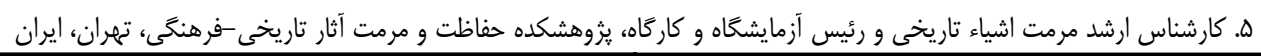

تاريخ يذيرش:

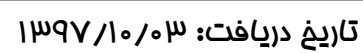

\begin{abstract}
جكيده

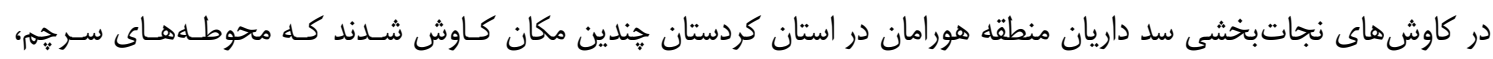

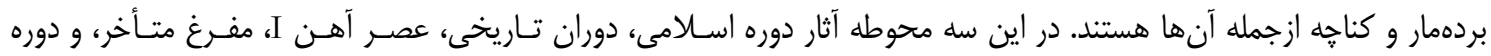

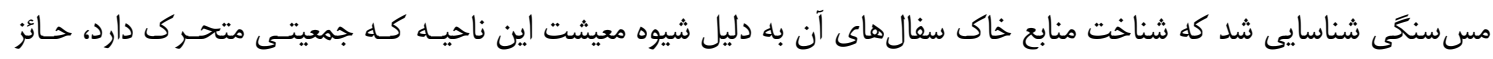

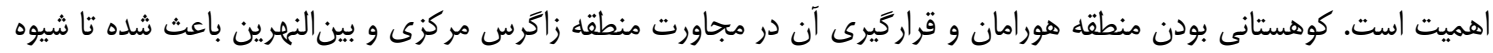

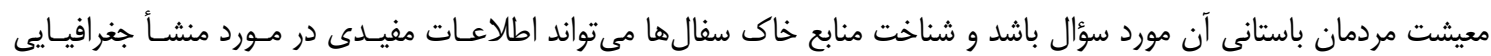

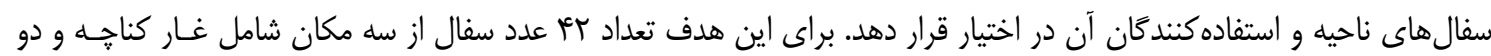

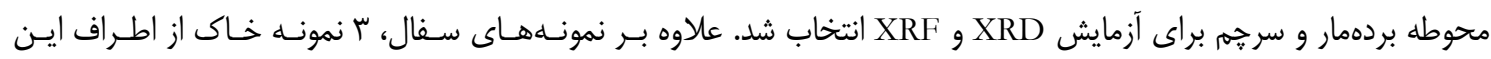

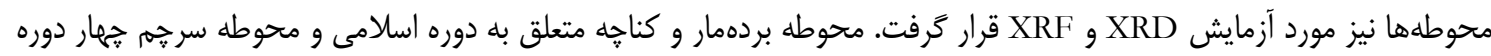

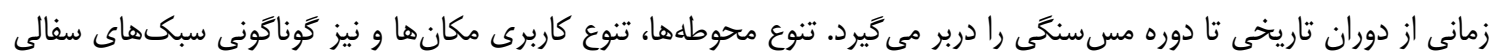

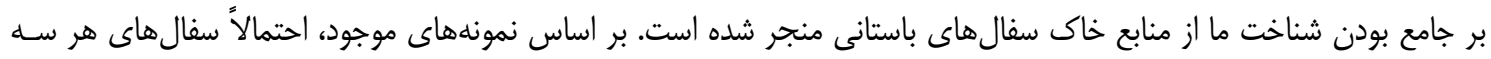

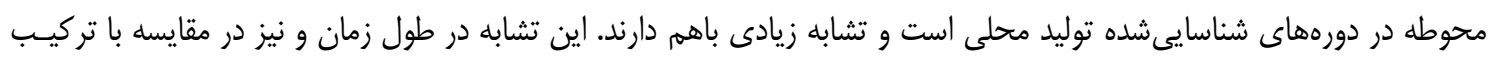

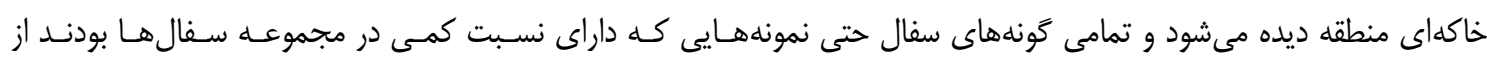

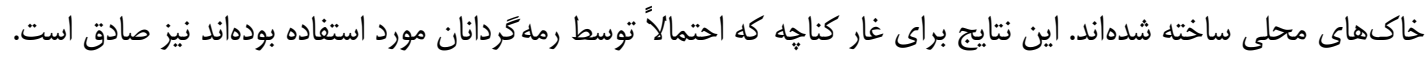

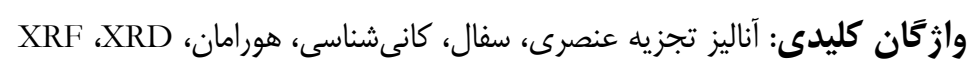

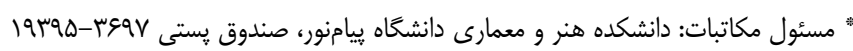

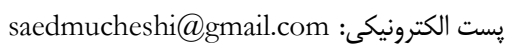

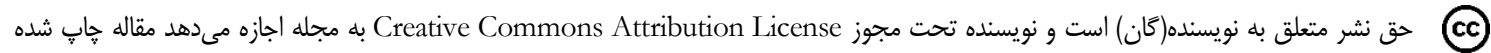

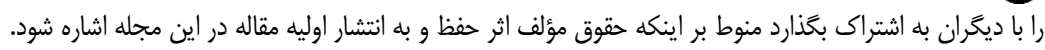


برخى از محوطههاى آن وجود داشته است بهعنوانمثال

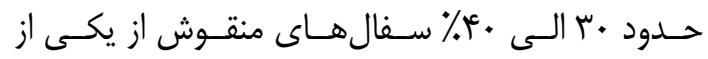

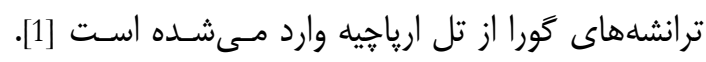

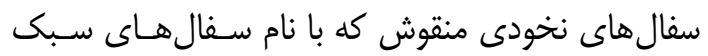

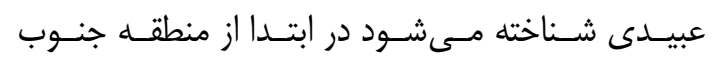

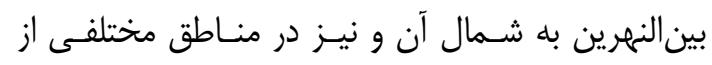

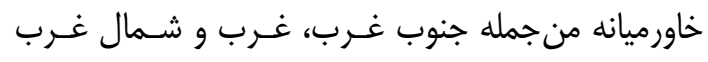

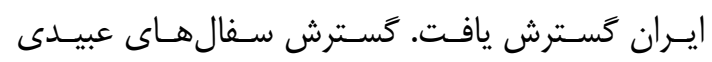

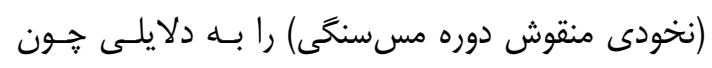

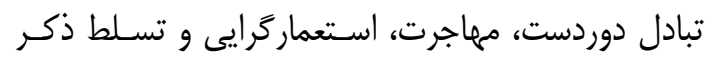

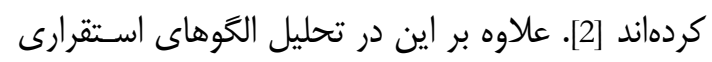

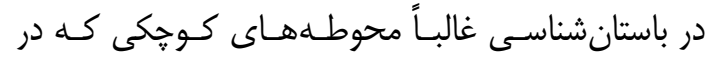

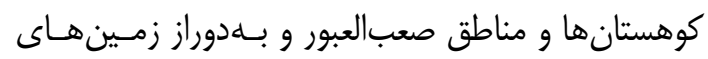

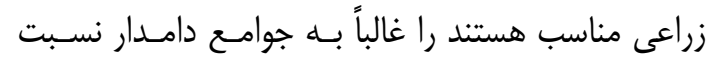

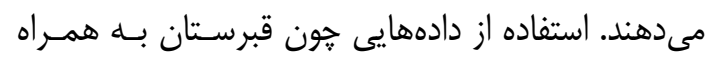

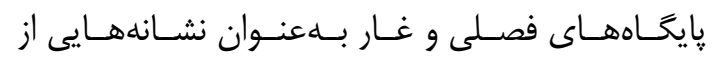

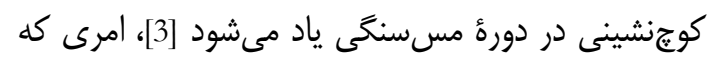

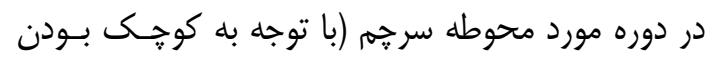

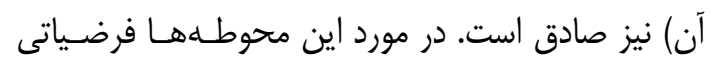

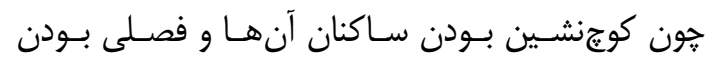

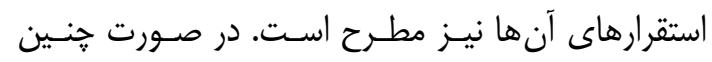

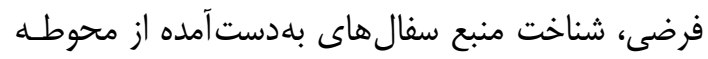

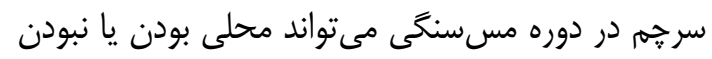

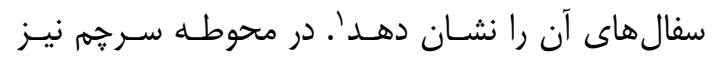

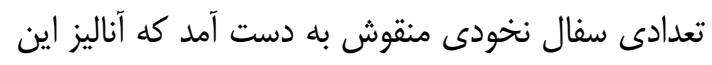

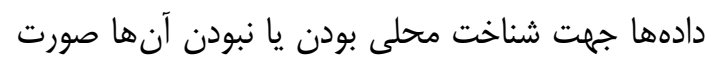

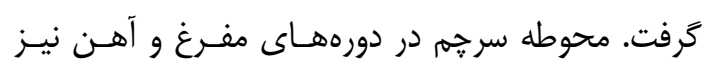

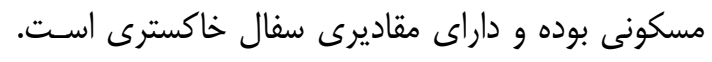

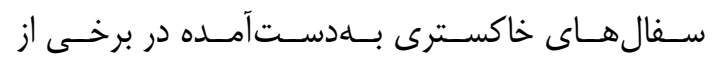

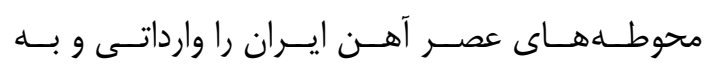

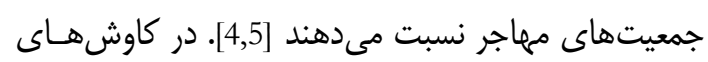
باباجان B همراه با طيف سفالى موسوم به سفال لرستان،

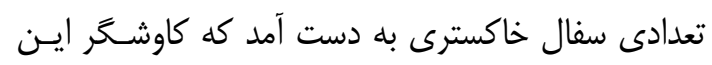

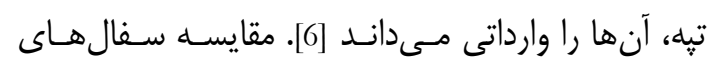

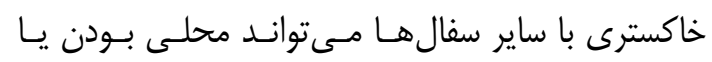

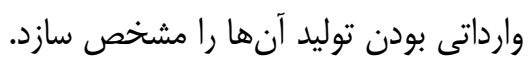

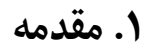

كاوشهاى نجاتبخشى سل داريان در اسـتان كردسـتان

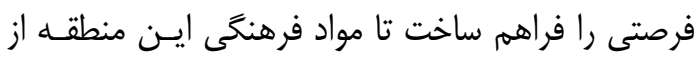

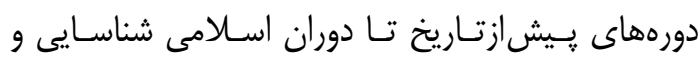

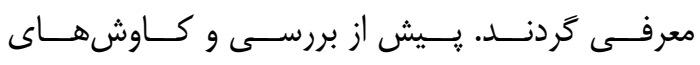

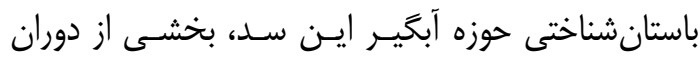

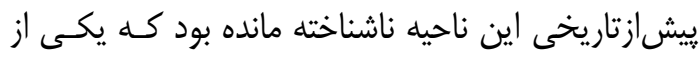

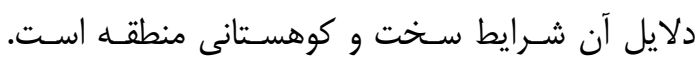

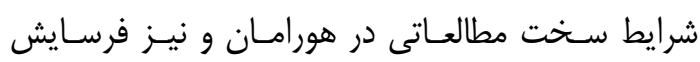

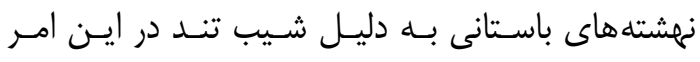

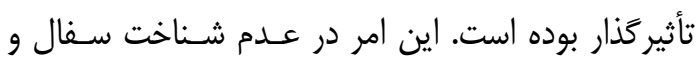

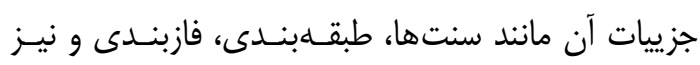

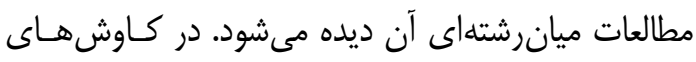
نجاتبخشى سد داريـان در منطقـهـه هورامـان در اسـتان

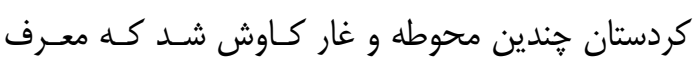

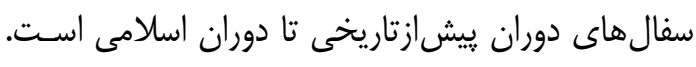

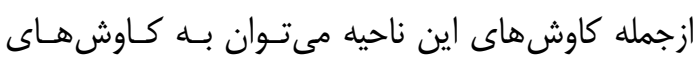

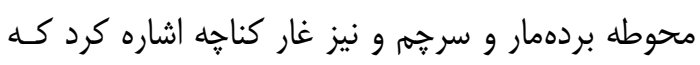

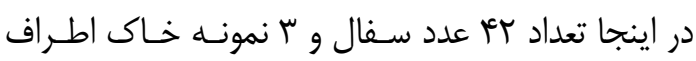

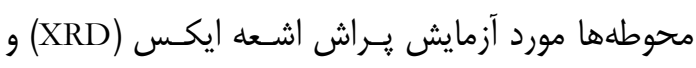
طيفسنجى فلورسانس يرتوايكس (XRF) قـرار ترفـت

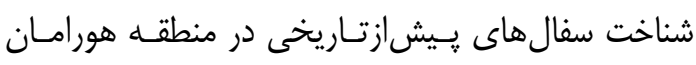

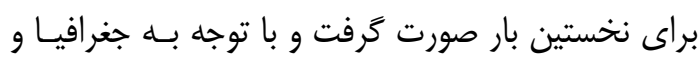

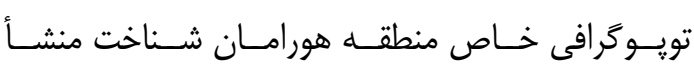

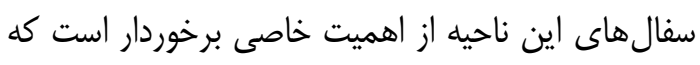
در اين مقاله موردبحث و بررسى قراركر فته است.

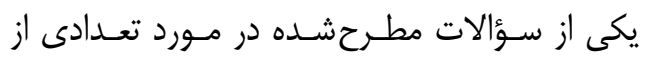

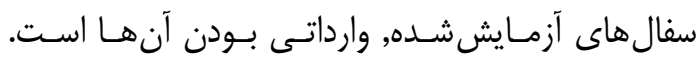

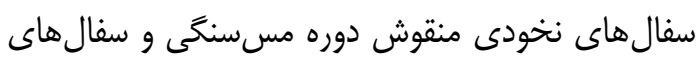

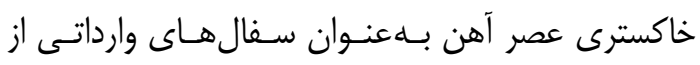

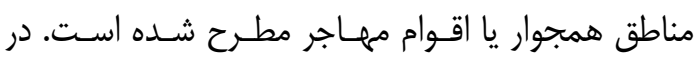

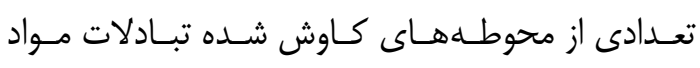

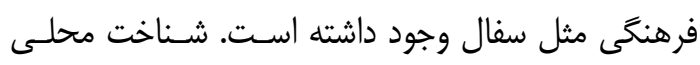
بودن يا نبودن آنها از طريق آزمايش سفال امكانيـذيـير

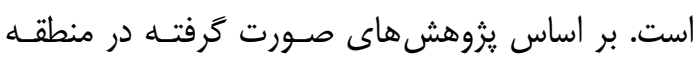

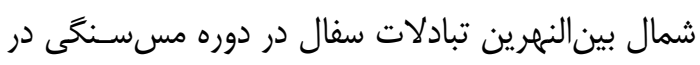


هوارها ديرتر رويش و نيز با تـأخير خشـك مسىشـوند. در

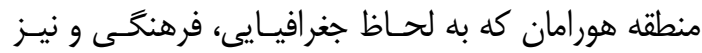

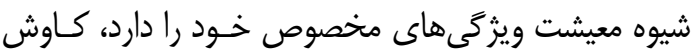
غار كناجه و محوطههاى بردهمار و سرجم در حوزه آبخيـر

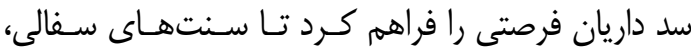

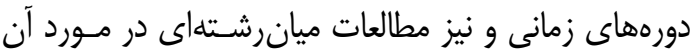

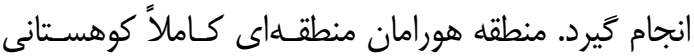
است كه شغل غالب مردم آن باغدار و دامــار بـوده و بــهـ سبب كوجهاى عمودى و نيز فروش محصولات باغى بـــ

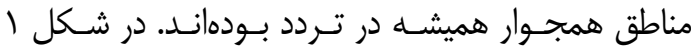

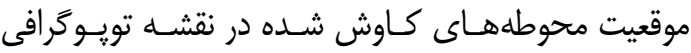

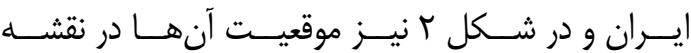
زمينشناسى ناحيه نمايش داده شده است. همان طـور كـهـ

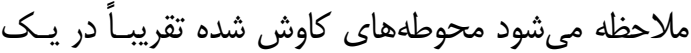

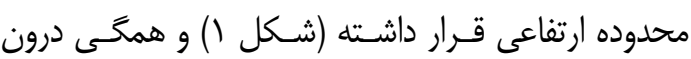
سنگَهاى آهكى مشابهى واقعشدهاند (شكل r r). r. جغر افياى منطقه

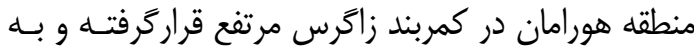

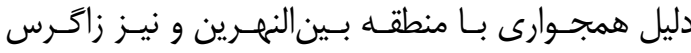

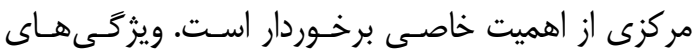
خاص جغرافيايى آن مانند كوههاى جِين خـورده و مرتفع،

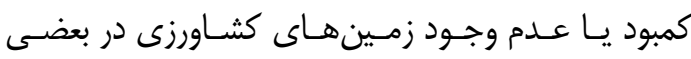
مناطق، و شيوه معيشت دامدارى و باغـدارى از خصـايص اين ناحيه است. بـهـ دليـل شـرايط كوهسـتانى هورامـان،

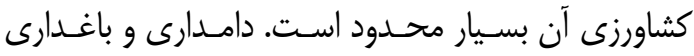

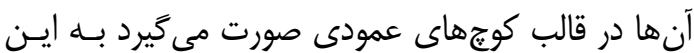

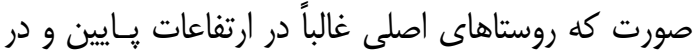

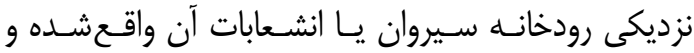
روستاهاى فصلى كه در فصل گَرما مسكونى مى كردند در

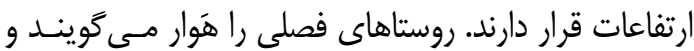

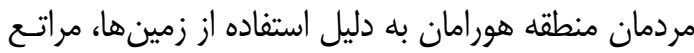

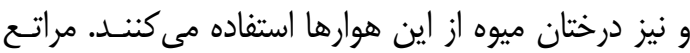

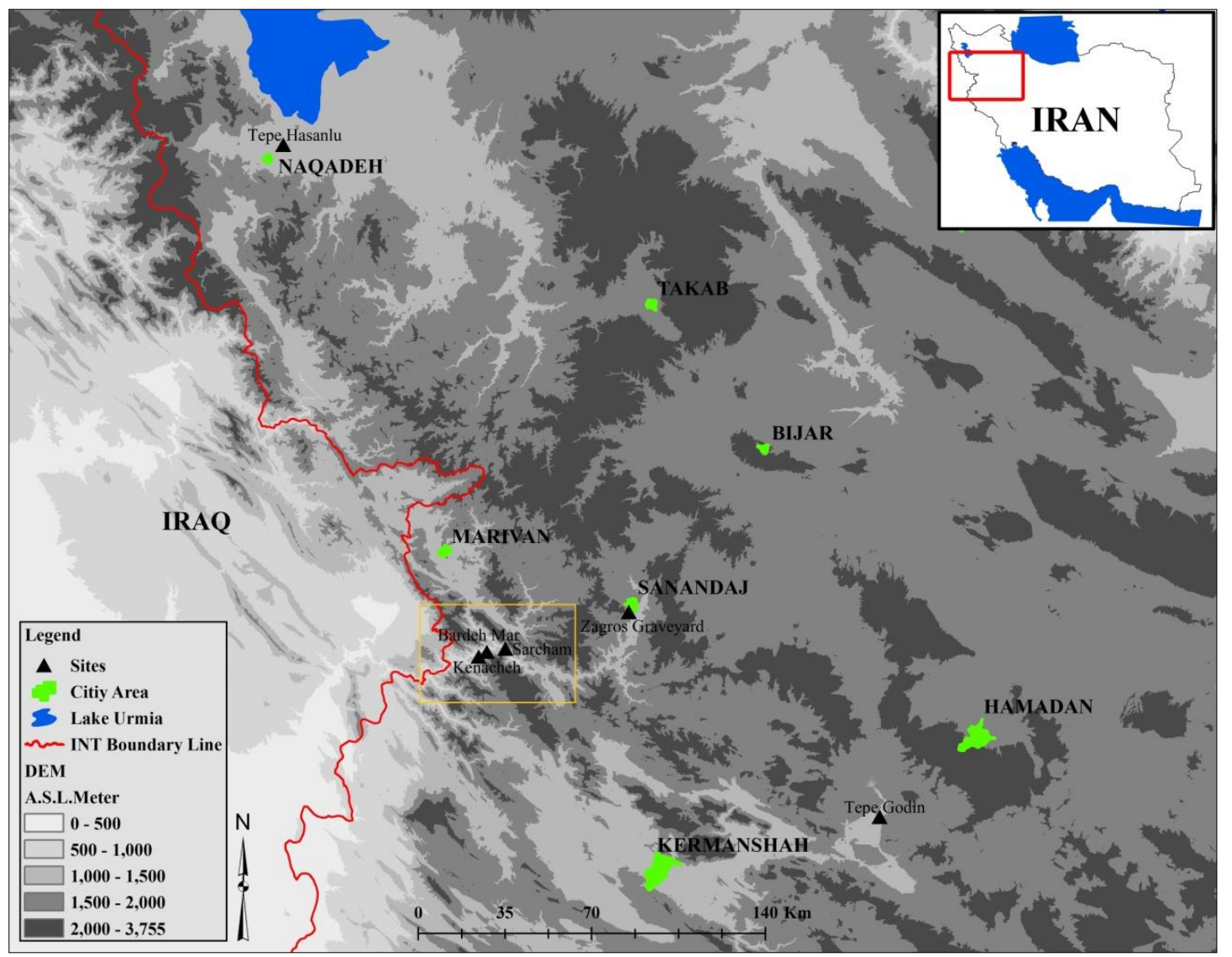

شكل (: نقشه محوطههاى بردمار، سرحم و كناجه در غرب ايران

Fig. 1: Map of Baredeh Mar, Sarcham and Konaha sites in western Iran 


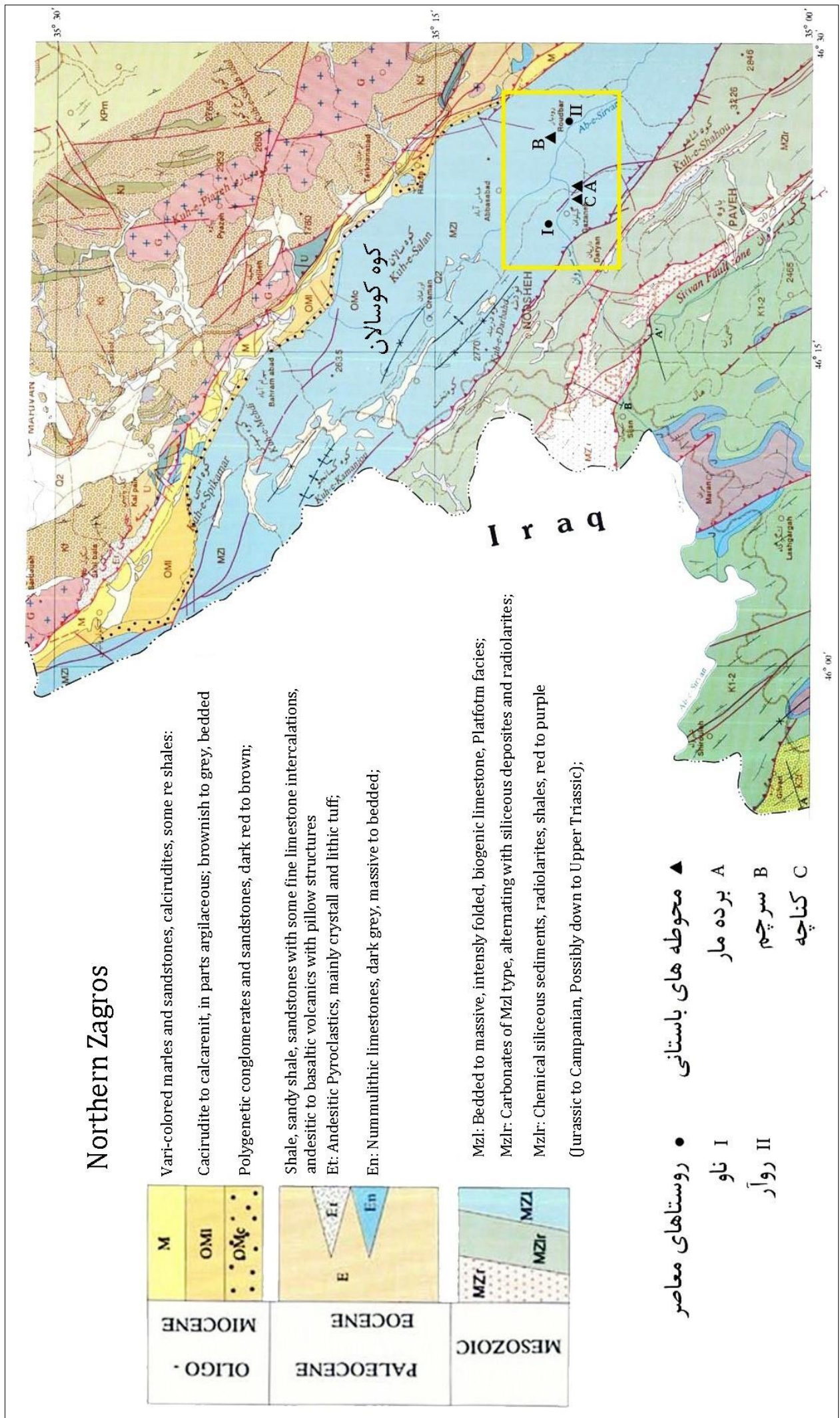

شكل ז: نقشه زمينشناسى ساده از منطقه هورامان [7] كه موقعيت محوطههاى موردمطالعه و مناطق سرجمه، بردهمار و كناجه در آن نمايش دادهشده است.

Fig. 2: Geological map of the region and the location of the studied sites and surrounding villages [6].

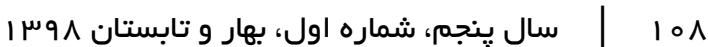


نيشابور[23] نيز نمونسههـاى ديخــــى از ايـن مطالعـات هستند كه در يزوهش نخست تفاوتهاى بين سفالهاى نهاى

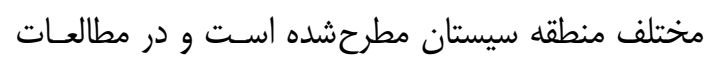

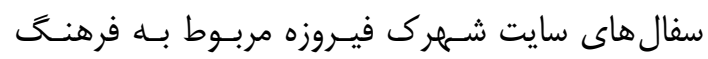

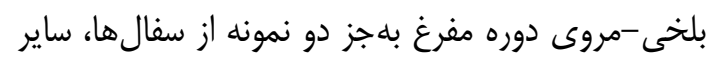
سفال ها از خاكهاى منطقه تهييه شدهاند.

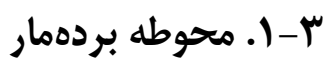

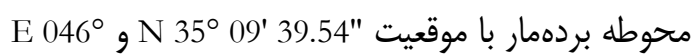
"14.34 '22 و ارتفاع عول مترى از سطح درياهـاى بآزاد؛

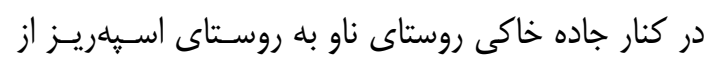

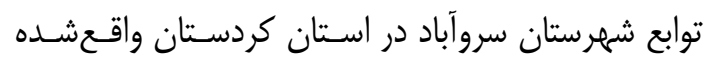

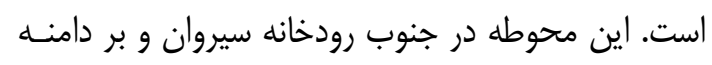

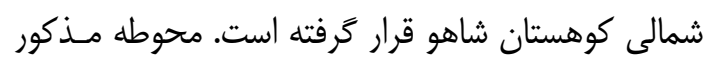

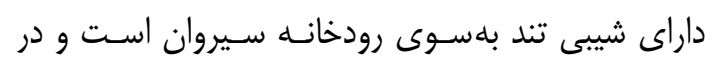

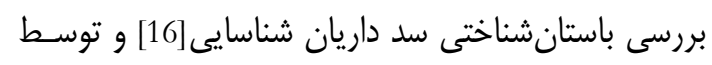

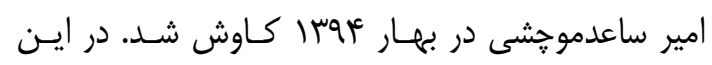

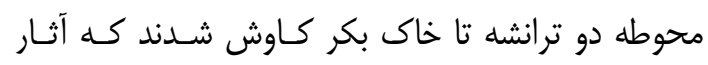

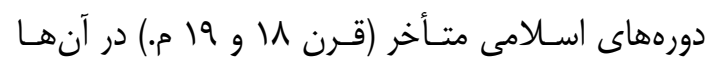

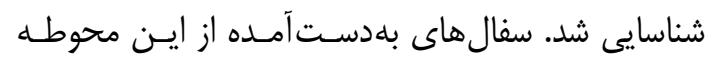
معرف سنت سفال هاى قهـوهاى دوران اسـلامى متــأخر

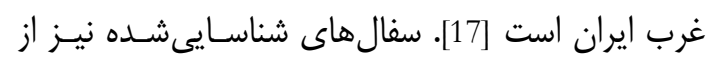

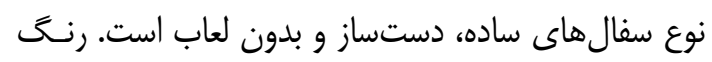

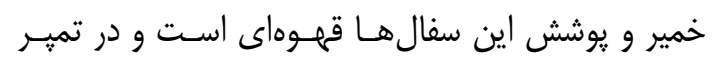

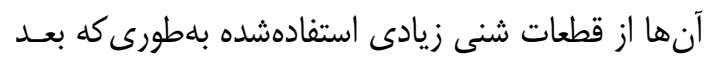

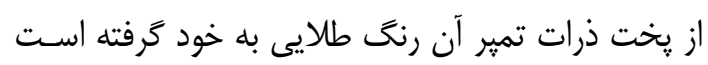

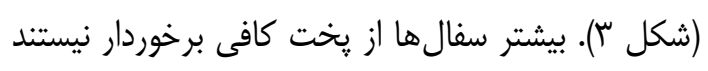

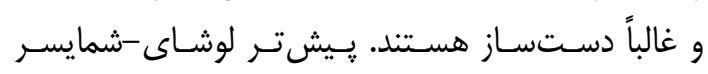

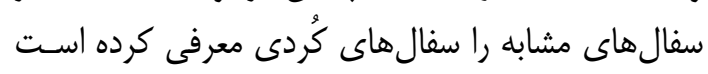

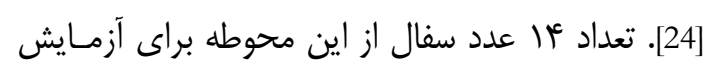
XRD

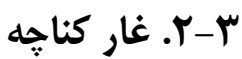

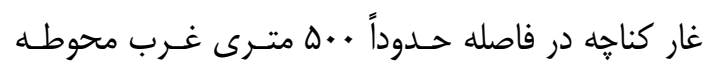

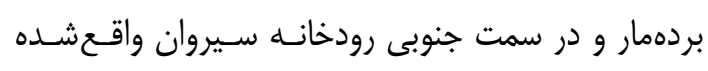

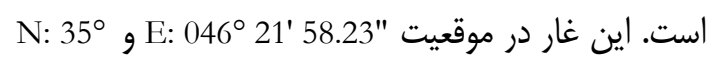

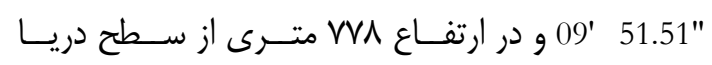

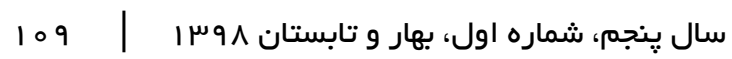

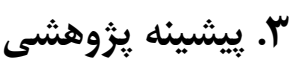

فعاليتهاى باستانشناختى مختلفى شامل شناسايى آثار،

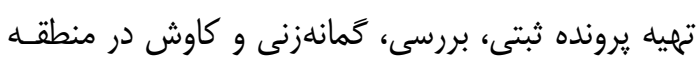

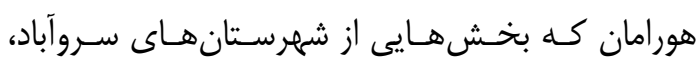

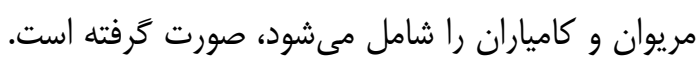

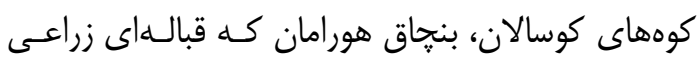
است در سـال ه.با ش كشـف و ترجمـهـ شـــ [10-8].

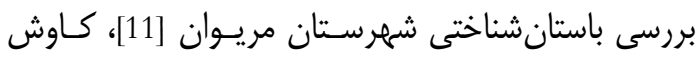

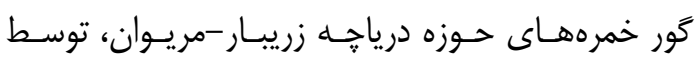

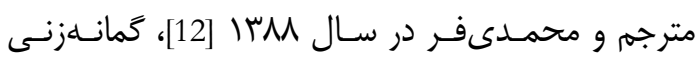

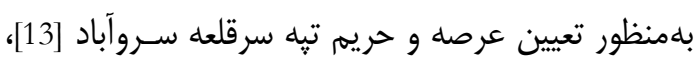
بررسى پارينهسنَى شهرستان هاى كاميـاران و سـروآباد

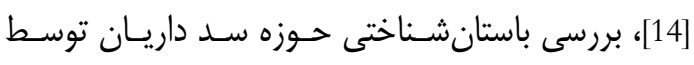

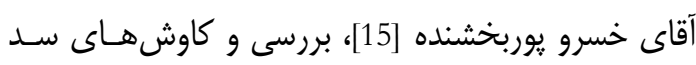

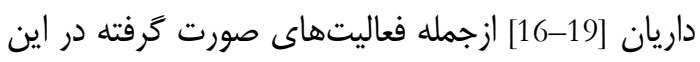

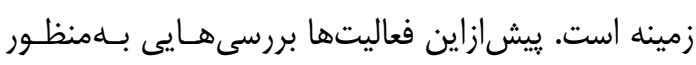

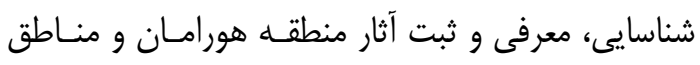
ييرامون آن توسط ميراث استان صورت كرفته است، كه

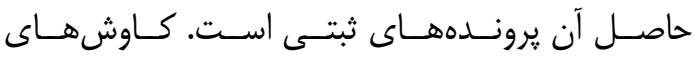

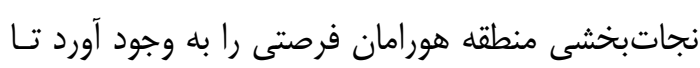

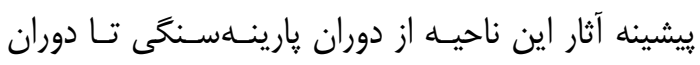

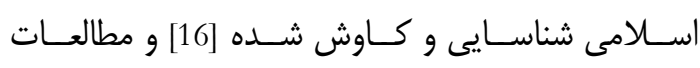

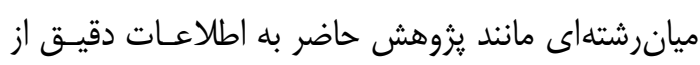
ساختار سفالهاى آن و نيز كانىهاى ايسن ناحيـه منجـر

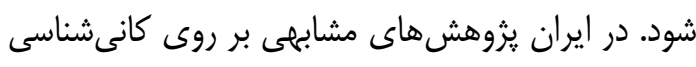

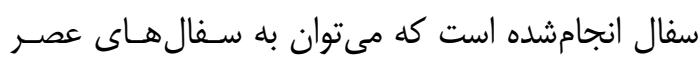
مفرغ كول تِه عجبشير [20]، و نيـز شناسـايى سـاختار

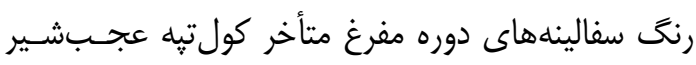

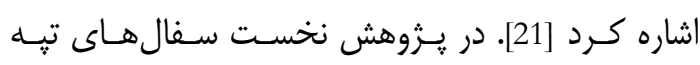

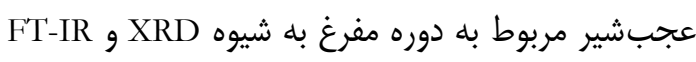
مورد آزمايش قرار كرفت و بر بر اساس نتـايج آن، يكسـان

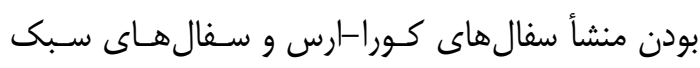

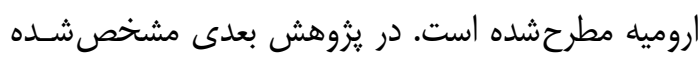

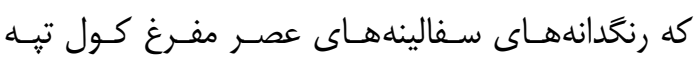

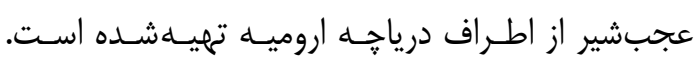

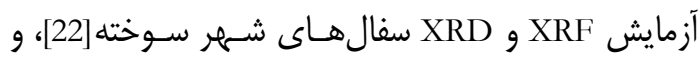

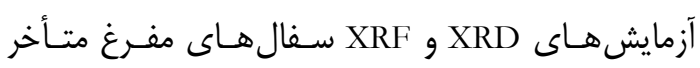




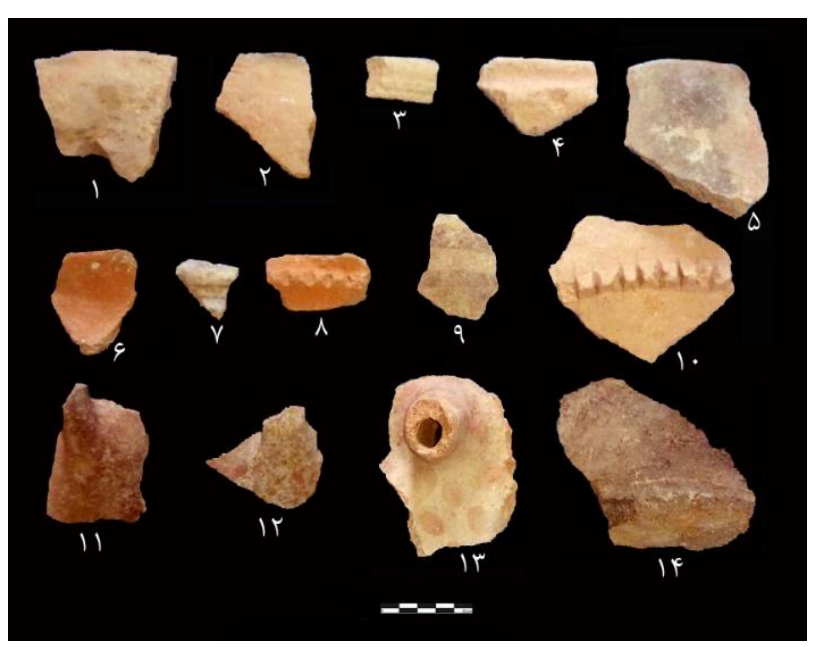

شكل ": سفال هاى بردمار، سفال قهوماى، دوره اسلامى متأخر

Fig. 3: Potteries of Bardeh Mar, brown potteries, late Islamic period

"41.75 '09 در ارتفاع MA مترى از سطح درياهاى آزاد و در شمال محل قديمَّ روستاى روآر از توابع شهرستان

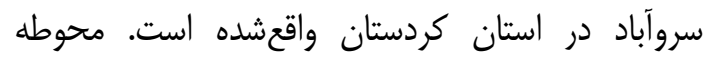

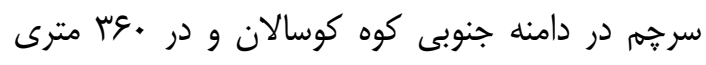

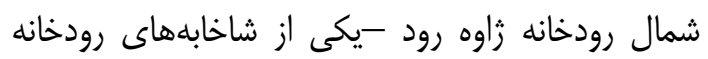

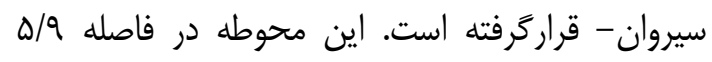

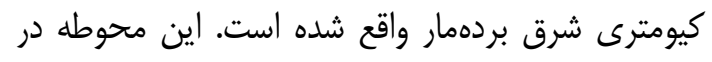
بررسى سد داريان شناسايى شد [18] و داراى جهار دار دوره

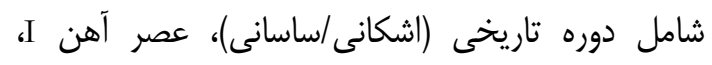

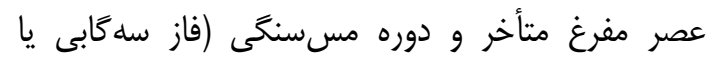

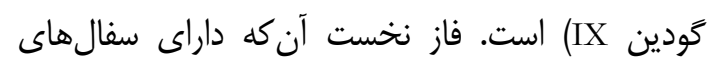

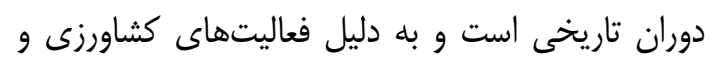

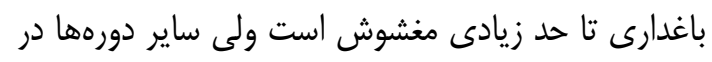
بافتهاى اوليه خود شناسايى شدند. در اين محوطه جيهار

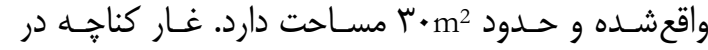
فاصله ..0 مترى غرب محوطه بردهمار قرار مرفته است.

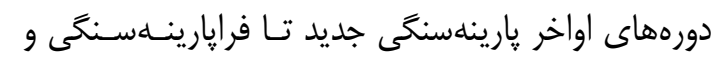

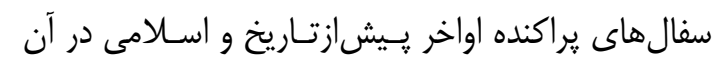
شناسايى شد. از لايههاى متأخرتر فوقانى قطعات سفال،

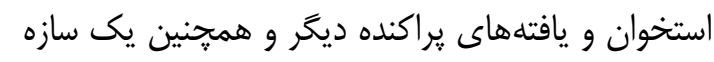

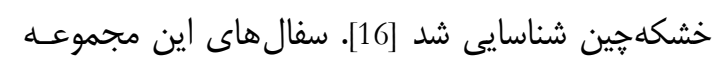

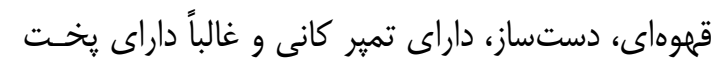
ناكافى، و يوشش قرمز-قهوهايى هستند (شكل عأ). تعداد

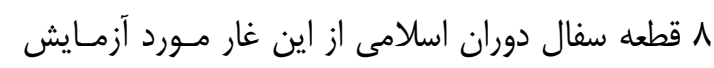
X و XRD "-r. محوطه سرجم

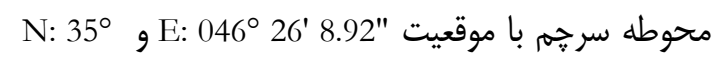

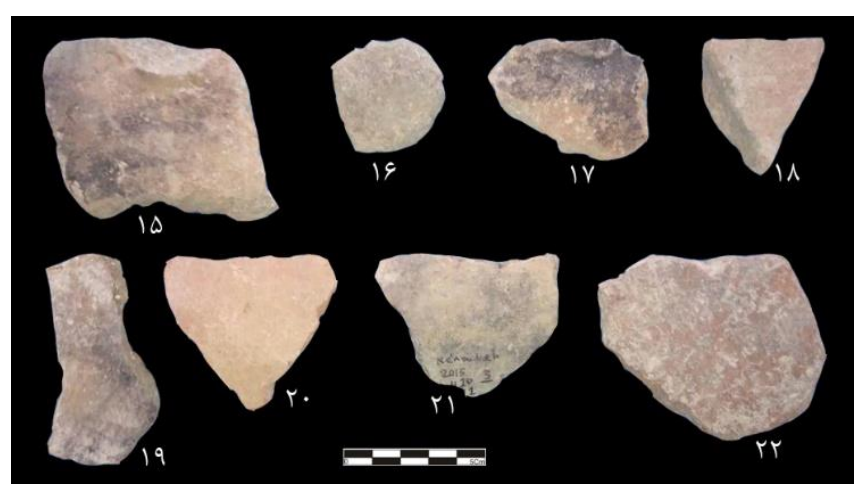

شكل t: سفال هاى غار كناهِ، سفال هاى قهوماى، دوره اسلامى متأخر

Fig. 4: Potteries of Kenacheh cave, brown potteries, late Islamic period

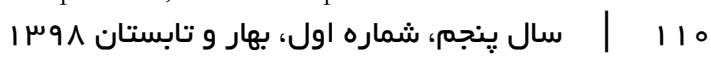




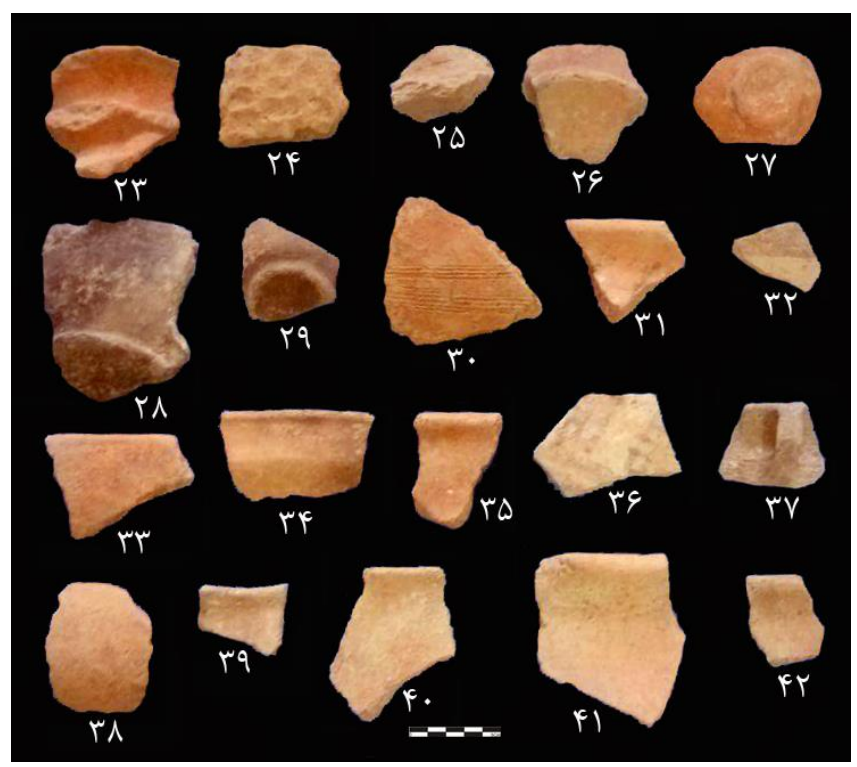

شكل ه: سفال هاى محوطه سرحم

Fig. 5: The potteries from the Sarcham area.

ارسـال شــده بــه آزمايشـعاه شـامل r rع قطعـه سـفال و

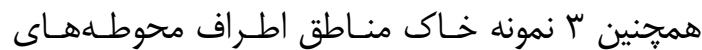
باستانى مىباشند كه نتايج اين آناليزها در جداول شـماره إهـره

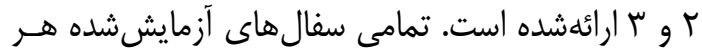

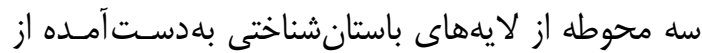

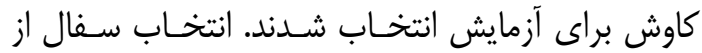
دورههاى مختلف براى شناسـايى احتمـالى سـفال هـاى

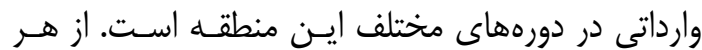

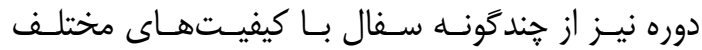

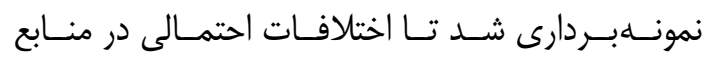
تشكيل دهنده آنها شناسايى گردد. استفاده از سفال هاى سلى بهدست آمده از غار كناجه نيز مى تواند اسـتفاده كنـــــان

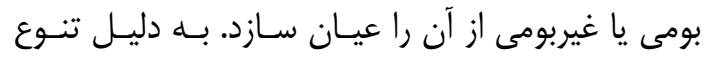

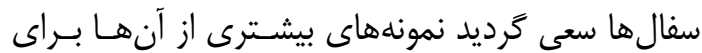

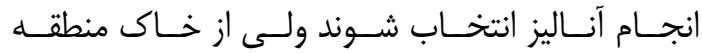

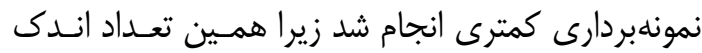

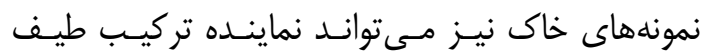
وسيعى از خاك منطقه باشند. همان طور كه در ادامه نيـز

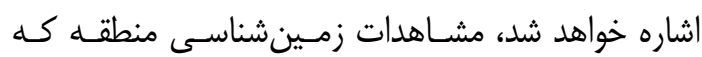

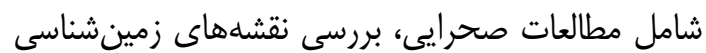

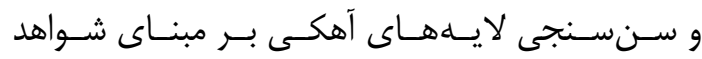

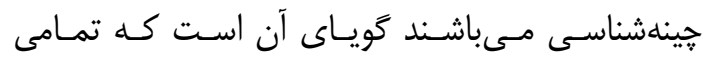

ترانشه A، B، C و D كاوش شد و آثار دوران تاريخى بـا

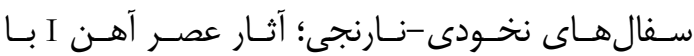
سفال هاى نخودى و خاكسترى؛ آثار دوره مفرغ متأخر با

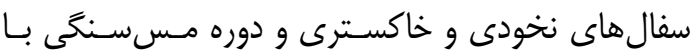

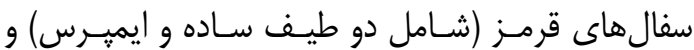

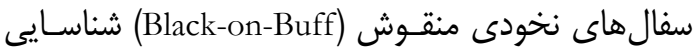

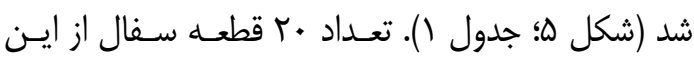

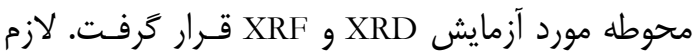

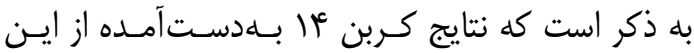

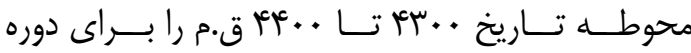

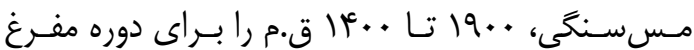

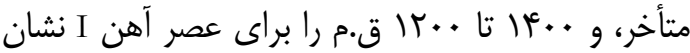
مى دهد. نتـايج ترمولومينسـانس سـفال هــاى لايسـه اول

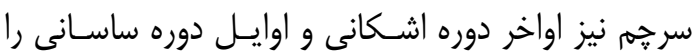
بيان مى كندّا.

\section{r أ. مواد و روشها}

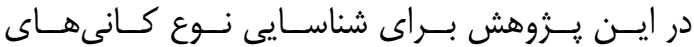

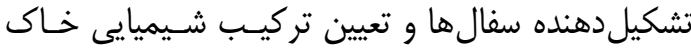
منطقه از روشهاى XRD و XRF آزمايشگاه يزوهشكده حفاظت و مرمت آثار تاريخى -فرهنگى يزوهشگاه ميراث فرهنگ

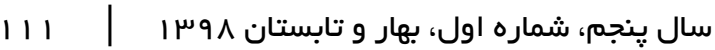


جدول (: مشخصات سفال هاى محوطه سرجم :

Table 1: Characteristics of the potteries in Sarcham site.

\begin{tabular}{|c|c|c|c|c|c|c|c|c|c|c|}
\hline $\begin{array}{c}\text { دوره ييشنهادى } \\
\text { Proposal } \\
\text { period }\end{array}$ & $\begin{array}{c}\text { كيفيت } \\
\text { Texture }\end{array}$ & $\begin{array}{c}\text { آميزه } \\
\text { Temper }\end{array}$ & $\begin{array}{l}\text { حرارت } \\
\text { Firing }\end{array}$ & $\begin{array}{c}\text { خارجى } \\
\text { Outer slip }\end{array}$ & $\begin{array}{c}\text { يوشش داخلى } \\
\text { Inner slip }\end{array}$ & تrnament & $\begin{array}{l}\text { Fi, } \\
\text { Paint }\end{array}$ & $\begin{array}{c}\text { تكنيك } \\
\text { ساخت } \\
\text { Technique }\end{array}$ & $\begin{array}{c}\text { ترانشه } \\
\text { Trench }\end{array}$ & $\begin{array}{c}\text { شماره } \\
\text { سفال } \\
\text { Pottery } \\
\text { Nr. }\end{array}$ \\
\hline $\begin{array}{c}\text { تاريخى } \\
\text { Historical }\end{array}$ & $\begin{array}{c}\text { متوسط } \\
\text { Medioum }\end{array}$ & $\begin{array}{l}\text { كانى } \\
\text { Grit }\end{array}$ & $\begin{array}{c}\text { كافى } \\
\text { Well-fired }\end{array}$ & - & - & $\begin{array}{c}\text { طنابى } \\
\text { Incised horizontal } \\
\text { line }\end{array}$ & $\begin{array}{c}\text { نارنجى } \\
\text { Orange }\end{array}$ & $\begin{array}{l}\text { جرخاز } \\
\text { Wheel- } \\
\text { made }\end{array}$ & $\mathrm{A}$ & 23 \\
\hline $\begin{array}{c}\text { تاريخى } \\
\text { Historical }\end{array}$ & $\begin{array}{c}\text { متوسط } \\
\text { Medioum }\end{array}$ & $\begin{array}{l}\text { Grit } \\
\text { Grit }\end{array}$ & $\begin{array}{c}\text { نافافى } \\
\text { Under- } \\
\text { fired }\end{array}$ & $\begin{array}{l}\text { رقيق } \\
\text { Thin }\end{array}$ & - & - & $\begin{array}{c}\text { نارنجى } \\
\text { Orange }\end{array}$ & $\begin{array}{c}\text { دستساز } \\
\text { Hande- } \\
\text { made }\end{array}$ & A & 25 \\
\hline $\begin{array}{c}\text { تاريخى } \\
\text { Historical }\end{array}$ & $\begin{array}{c}\text { متوسط } \\
\text { Medioum }\end{array}$ & $\begin{array}{l}\text { كانى } \\
\text { Grit }\end{array}$ & $\begin{array}{c}\text { كافى } \\
\text { Well-fired }\end{array}$ & $\begin{array}{c}\text { غليظ } \\
\text { Thick }\end{array}$ & $\begin{array}{c}\text { غليظ } \\
\text { Thick }\end{array}$ & - & $\begin{array}{c}\text { نارنجى } \\
\text { Orange }\end{array}$ & $\begin{array}{c}\text { دستساز } \\
\text { Hande- } \\
\text { made }\end{array}$ & $\mathrm{A}$ & 31 \\
\hline مسسنگى & خشن & $\begin{array}{l}\text { كياهى } \\
\text { Chaff }\end{array}$ & كافى & - & - & Impressed & $\begin{array}{c}\text { نارنجى } \\
\text { Orange }\end{array}$ & $\begin{array}{l}\text { دستساز } \\
\text { Hande- } \\
\text { made }\end{array}$ & $\mathrm{D}$ & 24 \\
\hline مسسنگى مhalcolithic & $\begin{array}{c}\text { متوسط } \\
\text { Medioum }\end{array}$ & $\begin{array}{l}\text { كياهى } \\
\text { Chaff }\end{array}$ & $\begin{array}{c}\text { كافى } \\
\text { Well-fired }\end{array}$ & $\begin{array}{c}\text { غليظ } \\
\text { Thick }\end{array}$ & $\begin{array}{c}\text { غليظ } \\
\text { Thick }\end{array}$ & Painted & $\begin{array}{l}\text { نخودى } \\
\text { Buff }\end{array}$ & $\begin{array}{l}\text { جرخساز } \\
\text { Wheel- } \\
\text { made }\end{array}$ & $\mathrm{D}$ & 32 \\
\hline مسسنَى & $\begin{array}{c}\text { متوسط } \\
\text { Medioum }\end{array}$ & $\begin{array}{l}\text { كياهى } \\
\text { Chaff }\end{array}$ & $\begin{array}{l}\text { ناكافى } \\
\text { Under- } \\
\text { fired }\end{array}$ & $\begin{array}{l}\text { رقيق } \\
\text { Thin }\end{array}$ & $\begin{array}{l}\text { رقيق } \\
\text { Thin }\end{array}$ & Painted & $\begin{array}{l}\text { نخودى } \\
\text { Buff }\end{array}$ & $\begin{array}{l}\text { جرخساز } \\
\text { Wheel- } \\
\text { made }\end{array}$ & $\mathrm{D}$ & 36 \\
\hline مسسنگى & $\begin{array}{c}\text { متوسط } \\
\text { Medioum }\end{array}$ & $\begin{array}{l}\text { كياهى } \\
\text { Chaff }\end{array}$ & كافى & $\begin{array}{c}\text { غليظ } \\
\text { Thick }\end{array}$ & $\begin{array}{c}\text { غليظ } \\
\text { Thick }\end{array}$ & - & $\begin{array}{l}\text { نخودى } \\
\text { Buff }\end{array}$ & $\begin{array}{c}\text { هرخساز } \\
\text { Wheel- } \\
\text { made }\end{array}$ & $\mathrm{D}$ & 33 \\
\hline $\begin{array}{l}\text { عصر آهن Iron age I } \\
\text { Ire }\end{array}$ & خشن & $\begin{array}{l}\text { كانى } \\
\text { Grit }\end{array}$ & $\begin{array}{l}\text { ناكافى } \\
\text { Under- } \\
\text { fired }\end{array}$ & $\begin{array}{l}\text { رقيق } \\
\text { Thin }\end{array}$ & $\begin{array}{l}\text { رقيق } \\
\text { Thin }\end{array}$ & - & $\begin{array}{c}\text { نارنجى } \\
\text { Orange }\end{array}$ & $\begin{array}{c}\text { دستساز } \\
\text { Hande- } \\
\text { made }\end{array}$ & $\mathrm{D}$ & 26 \\
\hline $\begin{array}{l}\text { I عصر آهن } \\
\text { Iron age I }\end{array}$ & $\begin{array}{c}\text { متوسط } \\
\text { Medioum }\end{array}$ & $\begin{array}{l}\text { Grit } \\
\text { Gانى }\end{array}$ & كافى & $\begin{array}{l}\text { رقيق } \\
\text { Thin }\end{array}$ & - & - & $\begin{array}{c}\text { نارنجى } \\
\text { Orange }\end{array}$ & $\begin{array}{l}\text { دستساز } \\
\text { Hande- } \\
\text { made }\end{array}$ & $\mathrm{D}$ & 35 \\
\hline $\begin{array}{l}\text { عصر آهن Iron age I } \\
\text { Ir }\end{array}$ & $\begin{array}{c}\text { متوسط } \\
\text { Medioum }\end{array}$ & $\begin{array}{l}\text { كانى } \\
\text { Grit }\end{array}$ & $\begin{array}{l}\text { ناكافى } \\
\text { Under- } \\
\text { fired }\end{array}$ & $\begin{array}{l}\text { رقيق } \\
\text { Thin }\end{array}$ & $\begin{array}{l}\text { رقيق } \\
\text { Thin }\end{array}$ & - & $\begin{array}{l}\text { نارنجى } \\
\text { Orange }\end{array}$ & $\begin{array}{c}\text { دستساز } \\
\text { Hande- } \\
\text { made }\end{array}$ & A & 42 \\
\hline $\begin{array}{l}\text { I عصر آهن } \\
\text { Iron age I }\end{array}$ & $\begin{array}{l}\text { ظريف } \\
\text { Fine }\end{array}$ & $\begin{array}{l}\text { كانى } \\
\text { Grit }\end{array}$ & كافى & - & - & - & $\begin{array}{l}\text { نارنجى } \\
\text { Orange }\end{array}$ & $\begin{array}{c}\text { دستساز } \\
\text { Hande- } \\
\text { made }\end{array}$ & A & 27 \\
\hline $\begin{array}{l}\text { عصر آهن Iron age I } \\
\text { Iren }\end{array}$ & متوسط & $\begin{array}{l}\text { كانى } \\
\text { Grit }\end{array}$ & $\begin{array}{c}\text { كافى } \\
\text { Well-fired }\end{array}$ & - & - & - & خاكسترى & $\begin{array}{l}\text { دستساز } \\
\text { Hande- } \\
\text { made }\end{array}$ & $\mathrm{D}$ & 29 \\
\hline $\begin{array}{l}\text { عصر آهن Iron age I } \\
\text { Iren }\end{array}$ & خشن & $\begin{array}{l}\text { كانى } \\
\text { Grit }\end{array}$ & $\begin{array}{c}\text { كافى } \\
\text { Well-fired }\end{array}$ & $\begin{array}{l}\text { رقيق } \\
\text { Thin }\end{array}$ & $\begin{array}{l}\text { رقيق } \\
\text { Thin }\end{array}$ & - & $\begin{array}{l}\text { نارنجى } \\
\text { Orange }\end{array}$ & $\begin{array}{l}\text { دستساز } \\
\text { Hande- } \\
\text { made }\end{array}$ & $\mathrm{D}$ & 37 \\
\hline $\begin{array}{l}\text { I عصر آهن I } \\
\text { Iron age I }\end{array}$ & متوسط & $\begin{array}{l}\text { كانى } \\
\text { Grit }\end{array}$ & $\begin{array}{c}\text { كافى } \\
\text { Well-fired }\end{array}$ & $\begin{array}{l}\text { رقيق } \\
\text { Thin }\end{array}$ & $\begin{array}{l}\text { رقيق } \\
\text { Thin }\end{array}$ & & $\begin{array}{l}\text { نارنجى } \\
\text { Orange }\end{array}$ & $\begin{array}{l}\text { دستساز } \\
\text { Hande- } \\
\text { made }\end{array}$ & $\mathrm{D}$ & 34 \\
\hline $\begin{array}{c}\text { مفرغ متأخر } \\
\text { Late bronze } \\
\text { age }\end{array}$ & متوسط & $\begin{array}{l}\text { كانى } \\
\text { Grit }\end{array}$ & $\begin{array}{l}\text { ناكافى } \\
\text { Under- } \\
\text { fired }\end{array}$ & $\begin{array}{l}\text { رقيق } \\
\text { Thin }\end{array}$ & $\begin{array}{l}\text { رقيق } \\
\text { Thin }\end{array}$ & - & خاكسترى & $\begin{array}{l}\text { دستساز } \\
\text { Hande- } \\
\text { made }\end{array}$ & $\mathrm{D}$ & 28 \\
\hline $\begin{array}{c}\text { مفرغ متأخر } \\
\text { Late bronze } \\
\text { age }\end{array}$ & 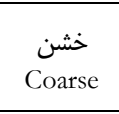 & $\begin{array}{l}\text { كانى } \\
\text { Grit }\end{array}$ & كافى & $\begin{array}{l}\text { غليظ } \\
\text { Thick }\end{array}$ & $\begin{array}{l}\text { رقيق } \\
\text { Thin }\end{array}$ & $\begin{array}{c}\text { Horizontal incised } \\
\text { lines }\end{array}$ & $\begin{array}{l}\text { نارنجى } \\
\text { Orange }\end{array}$ & $\begin{array}{c}\text { دستساز } \\
\text { Hande- } \\
\text { made }\end{array}$ & $\mathrm{D}$ & 30 \\
\hline $\begin{array}{c}\text { مفرغ متأخر } \\
\text { Late bronze } \\
\text { age }\end{array}$ & متوسط & $\begin{array}{l}\text { Grit } \\
\text { Grit }\end{array}$ & $\begin{array}{l}\text { ناكافى } \\
\text { Under- } \\
\text { fired }\end{array}$ & $\begin{array}{l}\text { رقيق } \\
\text { Thin }\end{array}$ & $\begin{array}{l}\text { رقيق } \\
\text { Thin }\end{array}$ & - & $\begin{array}{l}\text { نارنجى } \\
\text { Orange }\end{array}$ & $\begin{array}{c}\text { دستساز } \\
\text { Hande- } \\
\text { made }\end{array}$ & $\mathrm{D}$ & 39 \\
\hline $\begin{array}{c}\text { مفرغ متأخر } \\
\text { Late bronze } \\
\text { age }\end{array}$ & متوسط & $\begin{array}{l}\text { Grit } \\
\text { Gانى }\end{array}$ & $\begin{array}{c}\text { كافى } \\
\text { Well-fired }\end{array}$ & $\begin{array}{l}\text { رقيق } \\
\text { Thin }\end{array}$ & $\begin{array}{l}\text { رقيق } \\
\text { Thin }\end{array}$ & - & $\begin{array}{c}\text { نارنجى } \\
\text { Orange }\end{array}$ & $\begin{array}{c}\text { دستساز } \\
\text { Hande- } \\
\text { made }\end{array}$ & $\mathrm{D}$ & 40 \\
\hline $\begin{array}{c}\text { مفرغ متأخر } \\
\text { Late bronze } \\
\text { age }\end{array}$ & خشن & $\begin{array}{l}\text { كانى } \\
\text { Grit }\end{array}$ & كافى & $\begin{array}{l}\text { رقيق } \\
\text { Thin }\end{array}$ & $\begin{array}{l}\text { رقيق } \\
\text { Thin }\end{array}$ & - & $\begin{array}{c}\text { نارنجى } \\
\text { Orange }\end{array}$ & $\begin{array}{c}\text { دستساز } \\
\text { Hande- } \\
\text { made }\end{array}$ & $\mathrm{D}$ & 41 \\
\hline
\end{tabular}




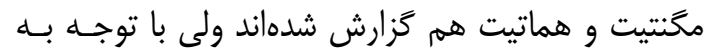

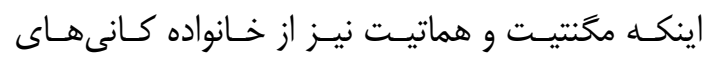

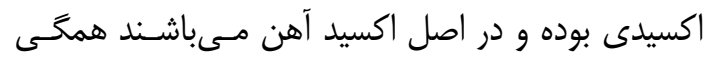

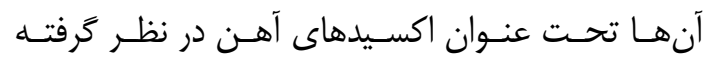

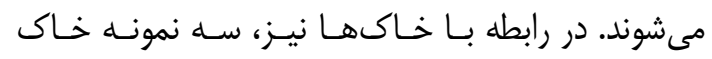

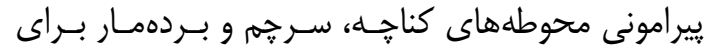

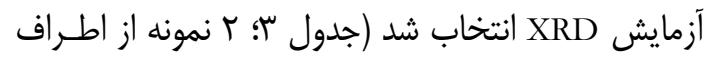
سرجهم و ا نمونه از اطراف بردمار و كناجه).

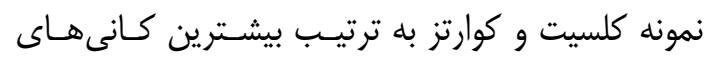

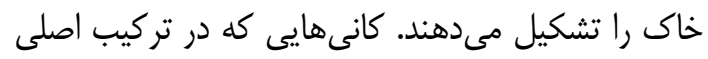
سفال هاى منطقه هم ديده مى تشود

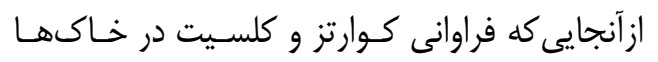

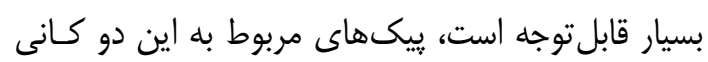

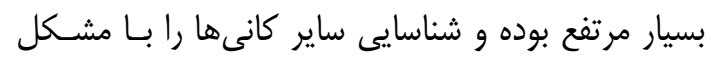

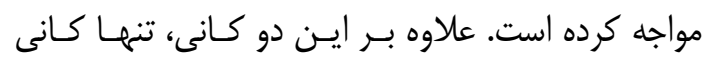

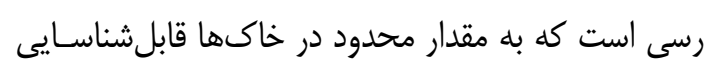

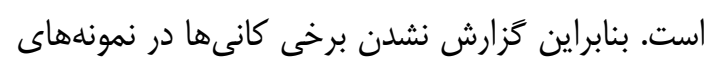

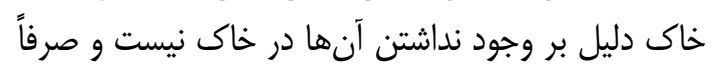

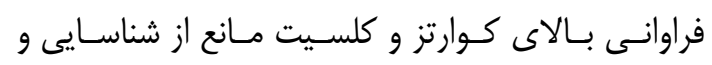
تشخيص آنها شده است.

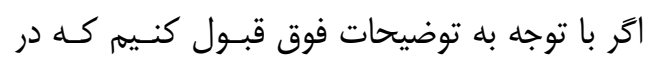

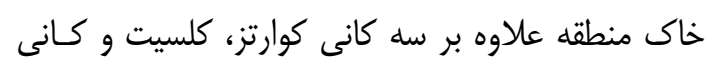

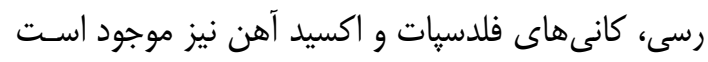
بازهم شناسايى خاك منطقه بلهعنوان منشأ سفال با با ابهام

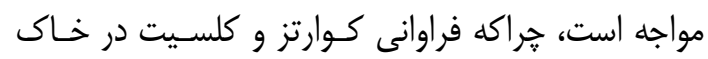
بسيار بيشتر از سفال است.

بلهنظور تفسير بهتر نتايج آزمايشهاى XRD و بـاـ

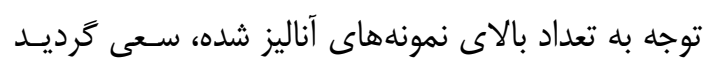

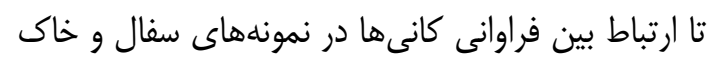

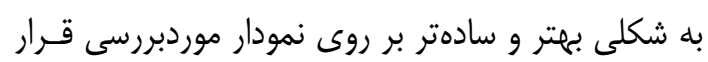

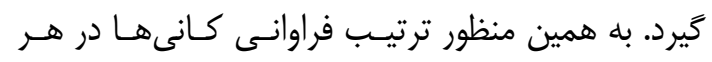

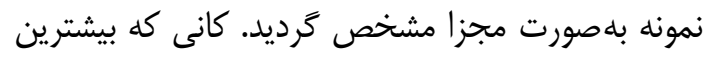

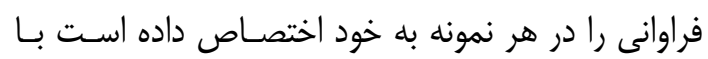

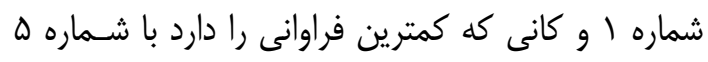
مشخص شدند. به همين صورت كانى هاى باى با شمارههاى

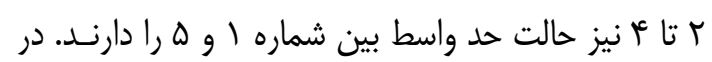

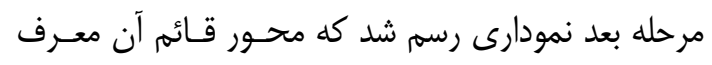

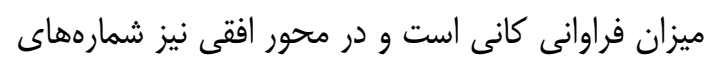

محوطهها بر روى يكى سازند زمينشناسى قراركرفتهانــــا

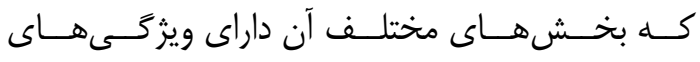

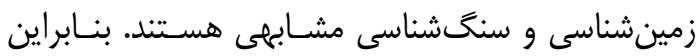

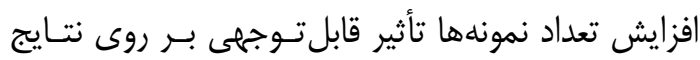

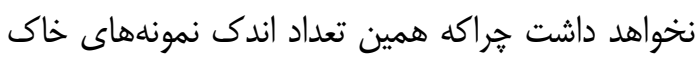

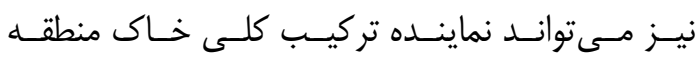

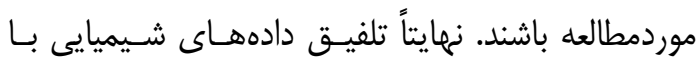

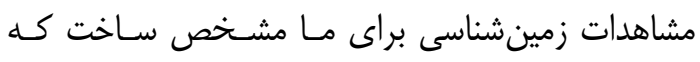

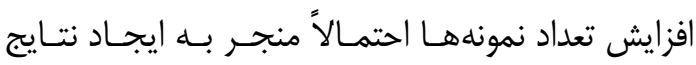

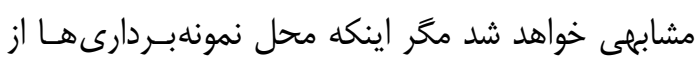

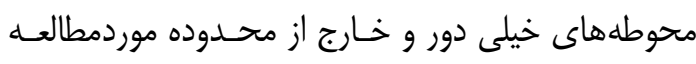

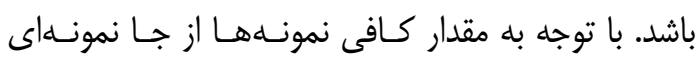

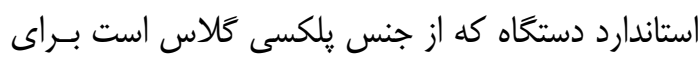

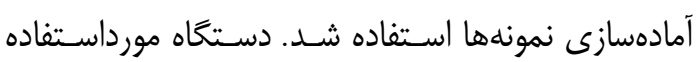
Seifert 3000T2T با تيـوب مس (40kV,30 mA) بـود.

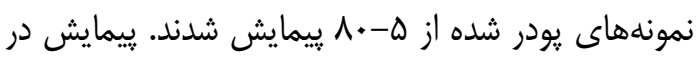

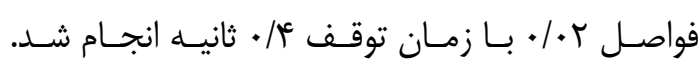

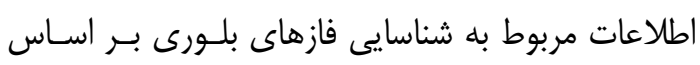

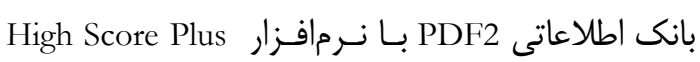

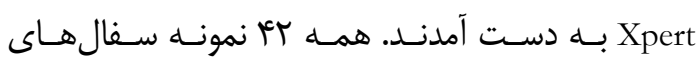

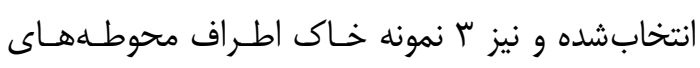

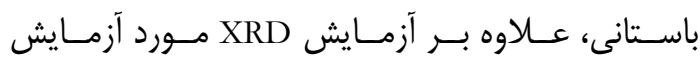

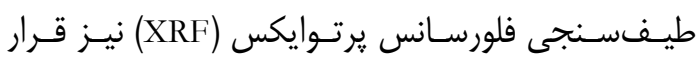

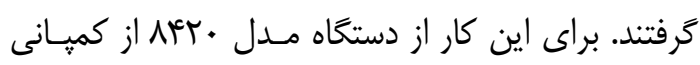

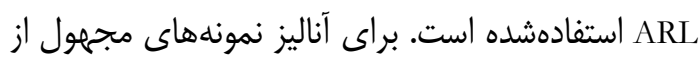

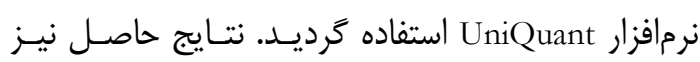

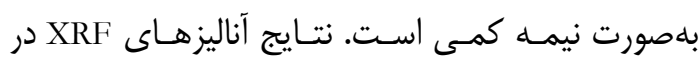

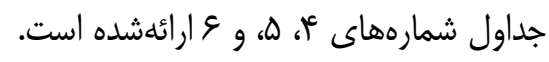

\section{f - أ. برآيند مطالعات طيفسنجى يراش ير توايكس (XRD)}

مطالعات XRD بر روى نمونههاى سـفال و خـاك؟

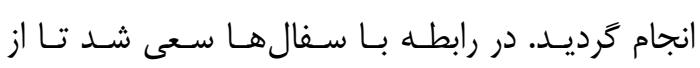

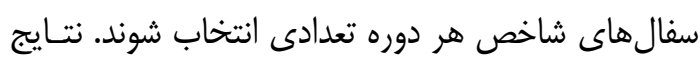

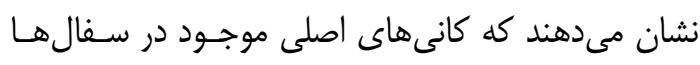

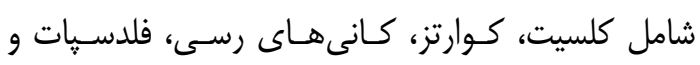

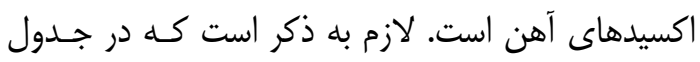

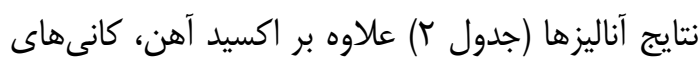


آنها كلسيت است احاطهشده است. بنابراين خـاكهـاى

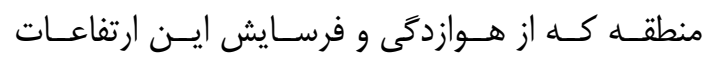

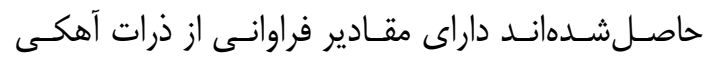

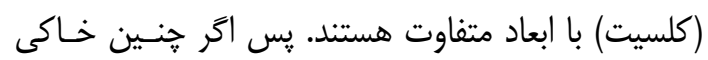

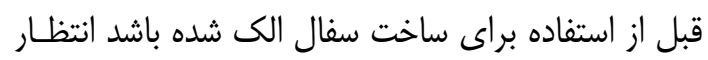

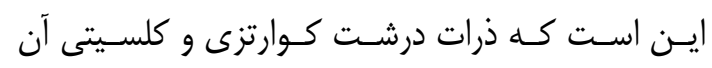

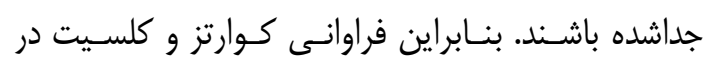

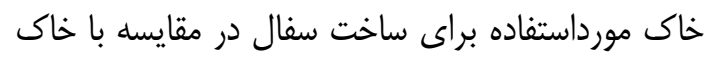

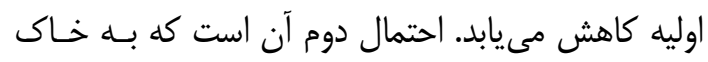

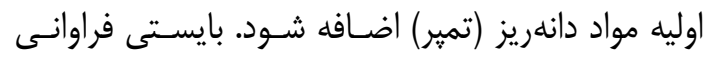
كانىهاى رسى، فلدسيات و اكسيد آهن در اين تمبر زياد

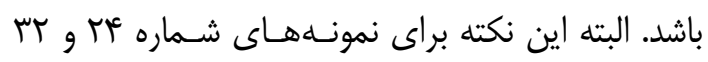

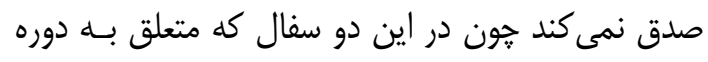

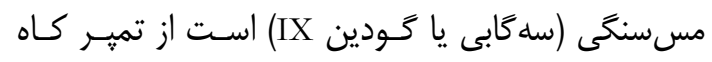
براى ساخت سفال استفادهشده است. بلهُور كلى با با توجنه

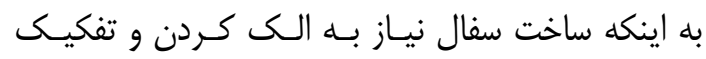

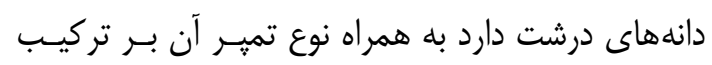
سفال تأثير كذار بوده است. استفاده از خاك منطقه براى تهيه سفال، در رابطهـ

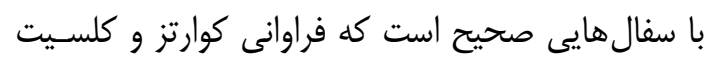

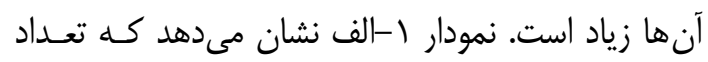

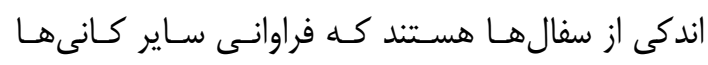

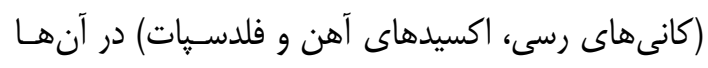

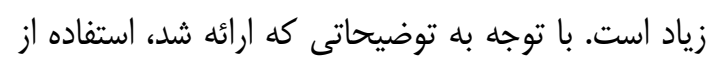

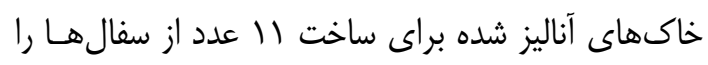

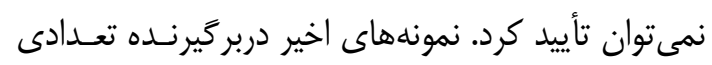

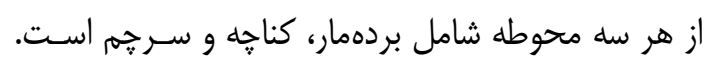

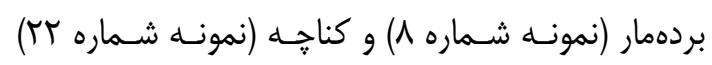

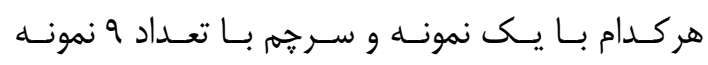

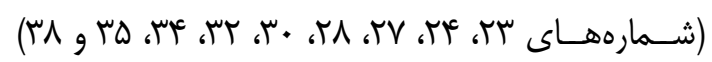

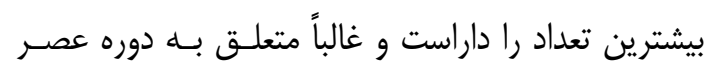

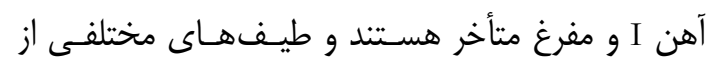

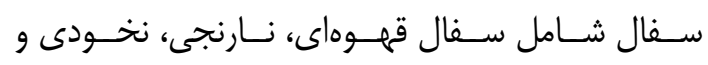

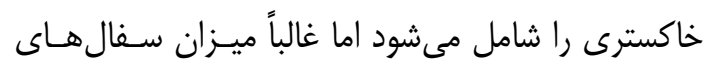

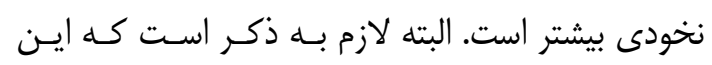

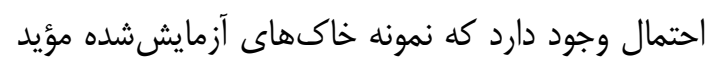
تمام نمونه خاكهاى منطقه نباشند.
ا تا ه نشان داده شده است (شكل 9). هر نوار رنكى كه

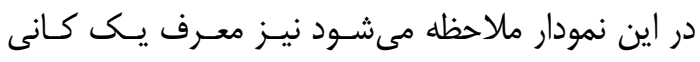

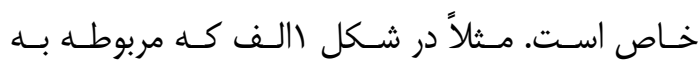

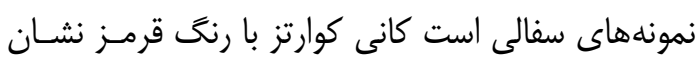

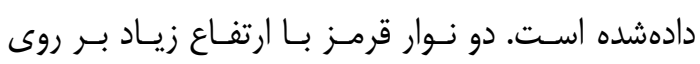

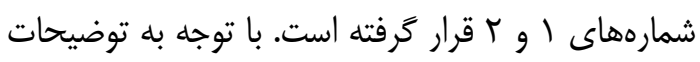

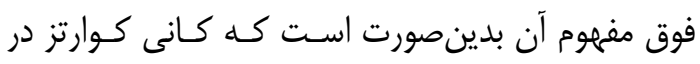

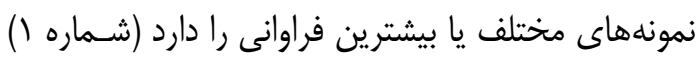

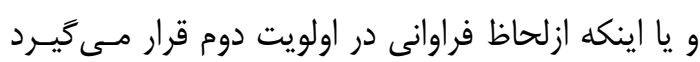

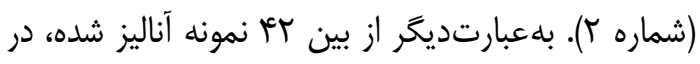

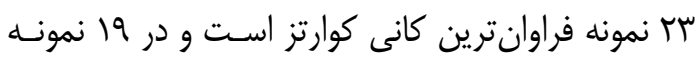

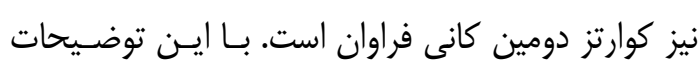
همان كونه كه ملاحظه مى شود در بيشتر نمونه دهاى آناليز

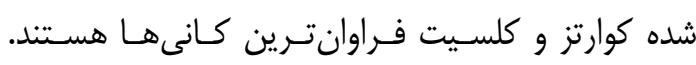

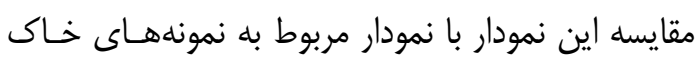

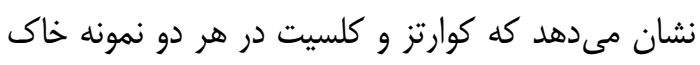

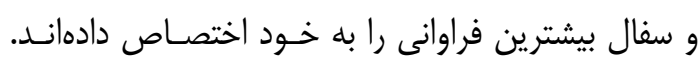

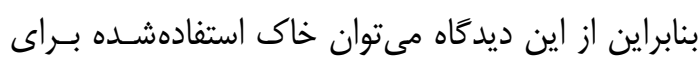

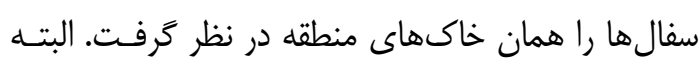

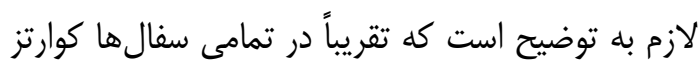

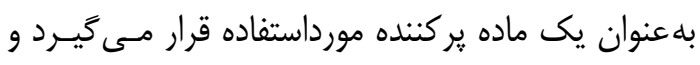

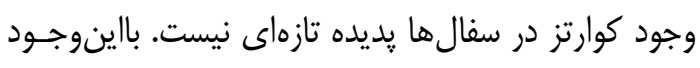

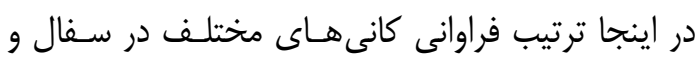

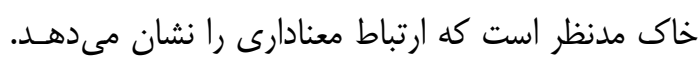

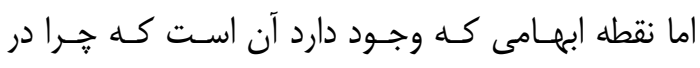

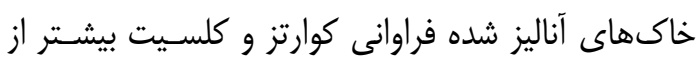

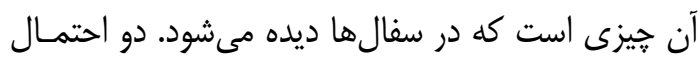

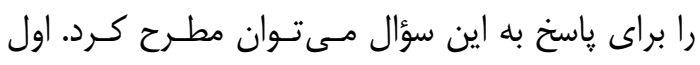

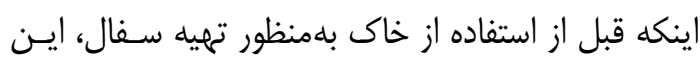

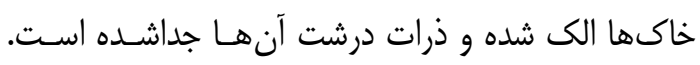

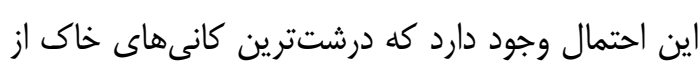

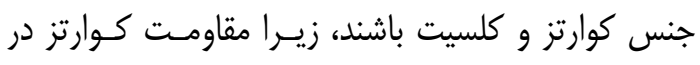

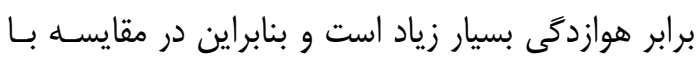

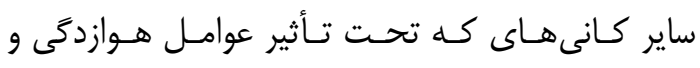

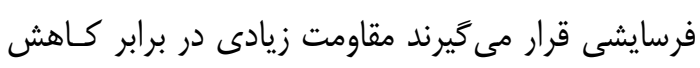

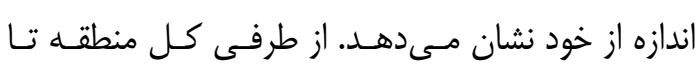
فواصل بسيار دور توسط ارتفاعات آهكى كه كانى اصـلى لنى 


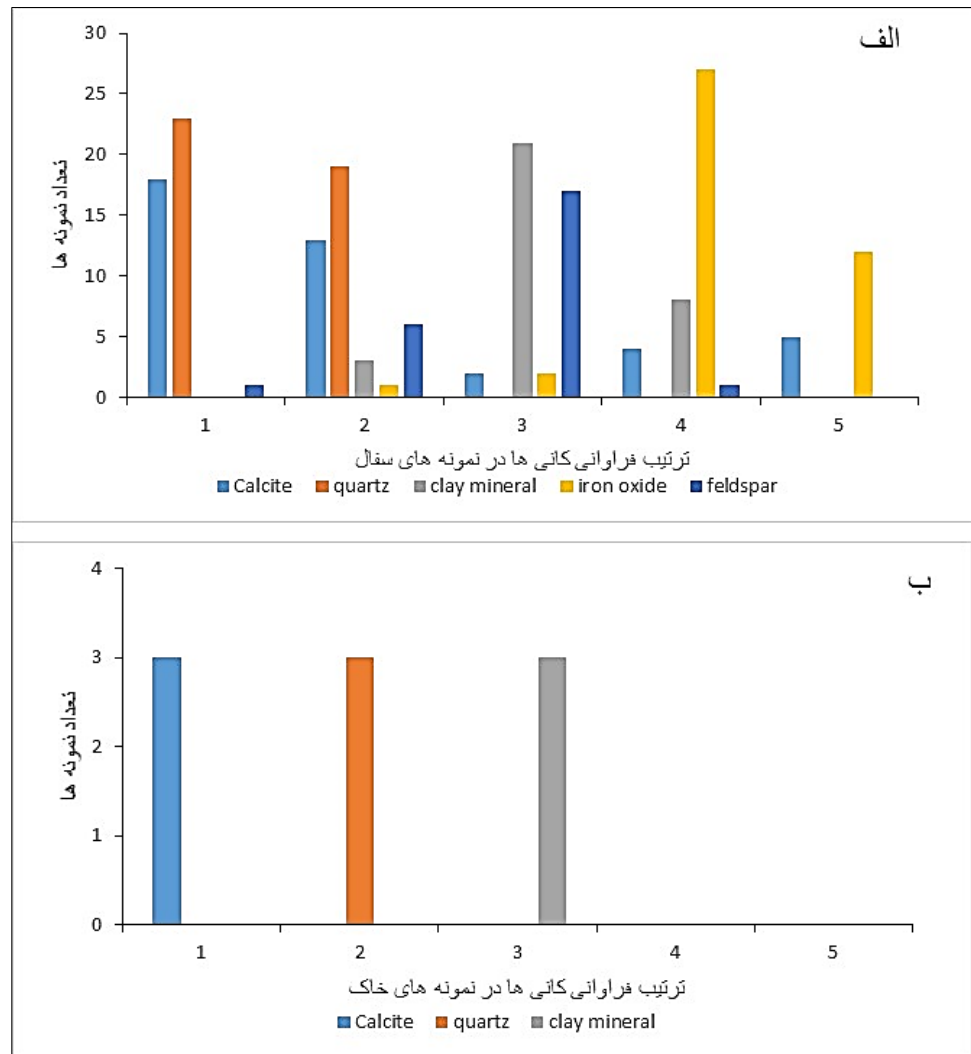

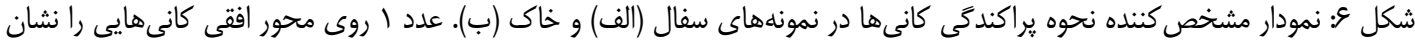

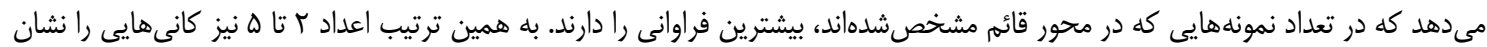

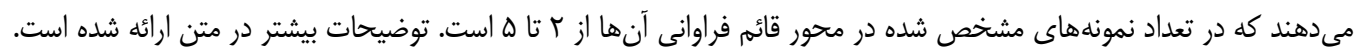

Fig. 6: The diagrams showing the distribution and abundance of the minerals in pottery (A) and soil (B). The number 1 in horizontal axis represents the minerals that are most abundant in the number of samples that showed in the vertical axis. As well as, numbers 2 to 5 represent the minerals that their orders of abundances are between 2 to 5 . The more details are presented in the text.

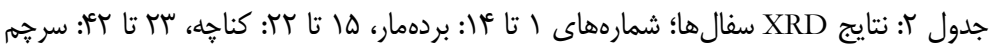

Table 2: The results of the XRD analyzes of the potteries. Samples 1 to 14 are from Bardeh Mar, 15 to 22 from Kenacheh and 23 to 42 from Sarcham

\begin{tabular}{|c|c|c|c|c|c|}
\hline $\begin{array}{c}\text { نتايج XRD، اسامى بله ترتيب اوانى است. } \\
\text { XRD result, names are in } \\
\text { order of abundance. }\end{array}$ & $\begin{array}{c}\text { دوره زمانى/نوع سفال } \\
\text { Period/Type of } \\
\text { pottery }\end{array}$ & $\begin{array}{l}\text { رديف } \\
\text { No. }\end{array}$ & $\begin{array}{l}\text { نتايج XRD } \\
\text { فراوانى اسامى به ترتيب. } \\
\text { XRD result, names are in } \\
\text { order of abundance. }\end{array}$ & $\begin{array}{c}\text { دوره زمانى /نوع } \\
\text { دفال } \\
\text { Period/Type of } \\
\text { pottery }\end{array}$ & $\begin{array}{l}\text { رديف } \\
\text { No. }\end{array}$ \\
\hline $\begin{array}{l}\text { Major phases: Quartz } \alpha \\
\text { Minor phases: Feldspar, Clay } \\
\text { mineral, Calcite, Magnetite }\end{array}$ & $\begin{array}{c}\text { اسلامى متأخر/قهوإى } \\
\text { Late Islamic } \\
\text { period/brwon }\end{array}$ & 22 & $\begin{array}{c}\text { Major phases:Calcite } \\
\text { Minor phases: Quartz } \alpha \text {, } \\
\text { Clay mineral, Hematite }(\alpha- \\
\left.\mathrm{Fe}_{2} \mathrm{O}_{3}\right)\end{array}$ & $\begin{array}{c}\text { متأخر /قهوالىاى } \\
\text { Late Islamic } \\
\text { period/brwon }\end{array}$ & 1 \\
\hline $\begin{array}{l}\text { Major phases: Quartz } \alpha \\
\text { Minor phases: Feldspar, Clay } \\
\text { mineral, Pyroxene, } \\
\text { Maghemite }\left(\gamma-\mathrm{Fe}_{2} \mathrm{O}_{3}\right)\end{array}$ & $\begin{array}{l}\text { تاريخى/نارنجى } \\
\text { Historical } \\
\text { period/orange }\end{array}$ & 23 & $\begin{array}{l}\text { Major phases: Calcite } \\
\text { Minor phases: Quartz } \alpha \text {, } \\
\text { Feldspar, } \mathrm{Fe}_{2} \mathrm{O}_{3} .1 \mathrm{H}_{2} \mathrm{O}\end{array}$ & $\begin{array}{c}\text { متأخر /قهوهاى } \\
\text { Late Islamic } \\
\text { period/brwon }\end{array}$ & 2 \\
\hline $\begin{array}{c}\text { Major phases: Quartz } \alpha \\
\text { Minor phases:Feldspar, Clay } \\
\text { mineral, Calcite, } \mathrm{Fe}_{2} \mathrm{O}_{3} .1 \% 2 \\
\mathrm{H}_{2} \mathrm{O}\end{array}$ & $\begin{array}{c}\text { مسسنگى/ايميرس } \\
\text { Chalcolithic/impress }\end{array}$ & 24 & $\begin{array}{l}\text { Major phases: Quartz } \alpha \\
\text { Minor phases: Calcite, } \\
\text { Feldspar, Pyroxene, Clay } \\
\text { mineral, } \mathrm{Maghemite}(\gamma- \\
\left.\mathrm{Fe}_{2} \mathrm{O}_{3}\right)\end{array}$ & $\begin{array}{c}\text { متأخر /قهوهاى } \\
\text { Late Islamic } \\
\text { period/brwon }\end{array}$ & 3 \\
\hline
\end{tabular}




\begin{tabular}{|c|c|c|c|c|c|}
\hline 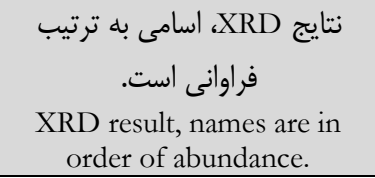 & $\begin{array}{l}\text { دوره زمانى/نوع سفال } \\
\text { Period/Type of } \\
\text { pottery }\end{array}$ & $\begin{array}{l}\text { رديف } \\
\text { No. }\end{array}$ & $\begin{array}{c}\text { نتايج XRD، اسامى به ترتيب } \\
\text { Xراوانى است. } \\
\text { XRD result, names are in } \\
\text { order of abundance. }\end{array}$ & $\begin{array}{c}\text { دوره زمانى /نوع } \\
\text { Period/Type of } \\
\text { pottery }\end{array}$ & $\begin{array}{l}\text { رديف } \\
\text { No. }\end{array}$ \\
\hline $\begin{array}{l}\text { Major phases: Calcite, Quartz } \\
\qquad \alpha \\
\text { Minor phases: Feldspar, Clay } \\
\text { mineral, Magnetite }\end{array}$ & $\begin{array}{l}\text { تاريخى/نارنجى } \\
\text { Historical } \\
\text { period/orange }\end{array}$ & 25 & $\begin{array}{l}\text { Major phases: Calcite } \\
\text { Minor phases: Quartz } \\
\alpha \text {,Clay mineral, Hematite } \\
\left(\alpha-\mathrm{Fe}_{2} \mathrm{O}_{3}\right)\end{array}$ & $\begin{array}{c}\text { متأخر /قهواموى } \\
\text { Late Islamic } \\
\text { period/brwon }\end{array}$ & 4 \\
\hline $\begin{array}{c}\text { Major phases: Calcite, Quartz } \\
\qquad \alpha \\
\text { Minor phases:Clay mineral, } \\
\text { Magnetite, Hematite }\end{array}$ & $\begin{array}{l}\text { عصر آهن I/نخودى I/buff } \\
\text { Iron Age I/but }\end{array}$ & 26 & $\begin{array}{c}\text { Major phases: Calcite, } \\
\text { Quartz } \alpha \\
\text { Minor phases:Clay mineral, } \\
\text { Magnetite }\left(\mathrm{Fe}_{3} \mathrm{O}_{4}\right)\end{array}$ & $\begin{array}{l}\text { متأخر /قهوهامى } \\
\text { Late Islamic } \\
\text { period/brwon }\end{array}$ & 5 \\
\hline $\begin{array}{l}\text { Major phases: Quartz } \alpha \\
\text { Minor phases: Feldspar, Clay } \\
\text { mineral, Hematite }\end{array}$ & $\begin{array}{c}\text { عصر آهن I/I/نارنجى } \\
\text { Iron Age I/Orange }\end{array}$ & 27 & $\begin{array}{l}\text { Major phases Quartz } \alpha \\
\text { Minor phases: Calcite, Clay } \\
\text { mineral, Magnetite }\left(\mathrm{Fe}_{3} \mathrm{O}_{4}\right)\end{array}$ & $\begin{array}{c}\text { متأخر /قهوهاى } \\
\text { Late Islamic } \\
\text { period/brwon }\end{array}$ & 6 \\
\hline $\begin{array}{c}\text { Major phases: Quartz } \alpha \\
\text { Minor phases:Calcite, } \mathrm{Fe}_{2} \mathrm{O}_{3}\end{array}$ & $\begin{array}{c}\text { مفرغ متأخر /خاكسترى } \\
\text { Late bronze } \\
\text { age/grey }\end{array}$ & 28 & $\begin{array}{c}\text { Major phases Calcite } \\
\text { Minor phases: Quartz } \alpha \text {, } \\
\text { Clay mineral } \\
\text { Hematite }\left(\alpha-\mathrm{Fe}_{2} \mathrm{O}_{3}\right)\end{array}$ & $\begin{array}{c}\text { متأخر /قهواماى } \\
\text { Late Islamic } \\
\text { period/brwon }\end{array}$ & 7 \\
\hline $\begin{array}{c}\text { Major phases: Quartz } \\
\alpha, \text { Calcite } \\
\text { Minor phases:Feldspar, } \\
\text { Magnetite }\end{array}$ & 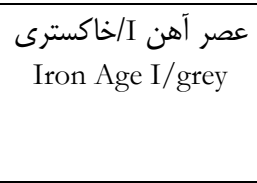 & 29 & $\begin{array}{l}\text { Major phases: Feldspar, } \\
\text { Quartz } \alpha \\
\text { Minor phases: Clay mineral, } \\
\text { Calcite, Hematite }\left(\alpha-\mathrm{Fe}_{2} \mathrm{O}_{3}\right)\end{array}$ & $\begin{array}{l}\text { متأخر /قهوهاى } \\
\text { Late Islamic } \\
\text { period/brwon }\end{array}$ & 8 \\
\hline $\begin{array}{c}\text { Major phases: Quartz } \alpha \\
\text { Minor phases: Feldspar, Clay } \\
\text { mineral, Maghemite }(\gamma- \\
\left.\mathrm{Fe}_{2} \mathrm{O}_{3}\right), \text { Calcite }\end{array}$ & $\begin{array}{l}\text { مفرغ متأخر /نخودى } \\
\text { Late bronze } \\
\text { age/Buff }\end{array}$ & 30 & $\begin{array}{l}\text { Major phases: Calcite } \\
\text { Minor phases: Quartz } \alpha \text {, } \\
\text { Clay mineral }\end{array}$ & $\begin{array}{l}\text { متأخر /قهوهاى } \\
\text { Late Islamic } \\
\text { period/brwon }\end{array}$ & 9 \\
\hline $\begin{array}{c}\text { Major phases: Calcite } \\
\text { Minor phases Quartz } \alpha \text {, } \\
\text { Feldspar, Clay mineral, } \\
\text { Hematite }\end{array}$ & $\begin{array}{l}\text { تاريخى/نارنجى } \\
\text { Historical } \\
\text { period/orange }\end{array}$ & 31 & $\begin{array}{c}\text { Major phases: Calcite } \\
\text { Minor phases: Quartz } \alpha \text {, } \\
\text { Clay mineral, } \\
\text { Magnetite }\left(\mathrm{Fe}_{3} \mathrm{O}_{4}\right)\end{array}$ & $\begin{array}{l}\text { متأخر /قهوامى } \\
\text { Late Islamic } \\
\text { period/brwon }\end{array}$ & 10 \\
\hline $\begin{array}{l}\text { Major phases: Quartz } \alpha \\
\text { Minor phases Feldspar, Clay } \\
\text { minerals, Magnetite, Calcite }\end{array}$ & $\begin{array}{l}\text { مسسنگى /نخودى } \\
\text { Chalcolithic/buff }\end{array}$ & 32 & $\begin{array}{c}\text { Major phases: Calcite, } \\
\text { Quartz } \alpha \\
\text { Minor phases:Clay mineral, } \\
\text { Feldspar }\end{array}$ & $\begin{array}{l}\text { متأخر /قهواماى } \\
\text { Late Islamic } \\
\text { period/brwon }\end{array}$ & 11 \\
\hline $\begin{array}{l}\text { Major phases: Quartz } \alpha \text {, } \\
\text { Calcite } \\
\text { Minor phases: Feldspar, Clay } \\
\text { mineral, Hematite }\end{array}$ & 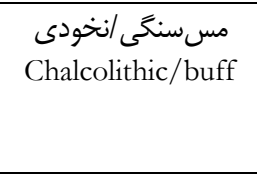 & 33 & $\begin{array}{l}\text { Major phases: Calcite, } \\
\text { Minor phases Quartz } \alpha \text {, } \\
\text { Clay mineral }\end{array}$ & $\begin{array}{l}\text { متأخر /قهواملى } \\
\text { Late Islamic } \\
\text { period/brwon }\end{array}$ & 12 \\
\hline $\begin{array}{c}\text { Major phases: Quartz } \alpha \\
\text { Minor phases Clay mineral, } \\
\text { Maghemite }\left(\gamma-\mathrm{Fe}_{2} \mathrm{O}_{3}\right) \\
\text { Calcite }\end{array}$ & $\begin{array}{l}\text { عصر آهن I/نخودى } \\
\text { Iron Age I/buff }\end{array}$ & 34 & $\begin{array}{l}\text { Major phases: Quartz } \alpha \text {, } \\
\text { Calcite } \\
\text { Minor phases:Feldspar }\end{array}$ & $\begin{array}{l}\text { متأخر /قهواملى } \\
\text { Late Islamic } \\
\text { period/brwon }\end{array}$ & 13 \\
\hline $\begin{array}{l}\text { Major phases: Quartz } \alpha \\
\text { Minor phases Feldspar, Clay } \\
\text { mineral, Magnetite, Calcite }\end{array}$ & $\begin{array}{l}\text { عصر آهن I/نخودى } \\
\text { Iron Age I/buff }\end{array}$ & 35 & $\begin{array}{c}\text { Major phases Quartz } \alpha \text {, } \\
\text { Calcite } \\
\text { Minor phases:Clay mineral, } \\
\text { Magnetite }\left(\mathrm{Fe}_{3} \mathrm{O}_{4}\right)\end{array}$ & $\begin{array}{c}\text { متأخر/قواسواى } \\
\text { Late Islamic } \\
\text { period/brwon }\end{array}$ & 14 \\
\hline $\begin{array}{l}\text { Major phases: Quartz } \alpha \\
\text { Minor phases: Calcite, Clay } \\
\text { mineral, Pyroxene }\end{array}$ & $\begin{array}{l}\text { مسسنگى /نخودى } \\
\text { Chalcolithic/buff }\end{array}$ & 36 & $\begin{array}{l}\text { Major phases: Quartz } \alpha \text {, } \\
\text { Calcite } \\
\text { Minor phases: Feldspar, } \\
\text { Clay mineral, Magnetite } \\
\left(\mathrm{Fe}_{3} \mathrm{O}_{4}\right)\end{array}$ & $\begin{array}{c}\text { متأخر /قهواسى } \\
\text { Late Islamic } \\
\text { period/brwon }\end{array}$ & 15 \\
\hline
\end{tabular}




\begin{tabular}{|c|c|c|c|c|c|}
\hline $\begin{array}{c}\text { فرايج XRD، نتى اسامى به ترتيب است. } \\
\text { XRD result, names are in } \\
\text { order of abundance. }\end{array}$ & $\begin{array}{c}\text { دوره زمانى/نوع سفال } \\
\text { Period/Type of } \\
\text { pottery }\end{array}$ & $\begin{array}{l}\text { رديف } \\
\text { No. }\end{array}$ & $\begin{array}{c}\text { نتايج XRD، اسامى به ترتيب } \\
\text { Xراوانى است. } \\
\text { XRD result, names are in } \\
\text { order of abundance. }\end{array}$ & $\begin{array}{c}\text { دوره زمانى /نوع } \\
\text { دفال } \\
\text { Period/Type of } \\
\text { pottery }\end{array}$ & $\begin{array}{l}\text { رديف } \\
\text { No. }\end{array}$ \\
\hline $\begin{array}{l}\text { Major phases: Quartz } \alpha \text {, } \\
\text { Calcite } \\
\text { Minor phases: Feldspar, } \\
\text { Hematite }\left(\alpha-\mathrm{Fe}_{2} \mathrm{O}_{3}\right)\end{array}$ & 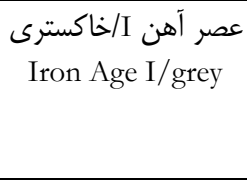 & 37 & $\begin{array}{c}\text { Major phases Quartz } \alpha \text {, } \\
\text { Calcite } \\
\text { Minor phases: Feldspar, } \\
\text { Clay mineral, Magnetite } \\
\left(\mathrm{Fe}_{3} \mathrm{O}_{4}\right)\end{array}$ & $\begin{array}{c}\text { متأخر/قهواماى } \\
\text { Late Islamic } \\
\text { period/brwon }\end{array}$ & 16 \\
\hline $\begin{array}{l}\text { Major phases: Quartz } \alpha \\
\text { Minor phases: Feldspar, } \\
\text { Calcite, Pyroxene, } \\
\mathrm{Fe}_{2} \mathrm{O}_{3} .1{ }_{2} \mathrm{H}_{2} \mathrm{O}\end{array}$ & مسسنگى/قرمز & 38 & $\begin{array}{l}\text { Major phases Calcite, } \\
\text { Minor phases Quartz, Clay } \\
\text { mineral, Magnetite }\left(\mathrm{Fe}_{3} \mathrm{O}_{4}\right)\end{array}$ & $\begin{array}{c}\text { متأخر /قهوامىى } \\
\text { Late Islamic } \\
\text { period/brwon }\end{array}$ & 17 \\
\hline $\begin{array}{c}\text { Major phases: Calcite, Quartz } \\
\alpha \\
\text { Minor phases Feldspar, } \\
\text { Maghemite }\end{array}$ & $\begin{array}{c}\text { مفرغ متأخر/نخودى } \\
\text { Late bronze } \\
\text { age/buff }\end{array}$ & 39 & $\begin{array}{c}\text { Major phases: Quartz } \alpha \text {, } \\
\text { Minor phases: Calcite, } \\
\text { Feldspar, Magnetite }\end{array}$ & $\begin{array}{c}\text { متأخر /قهواماى } \\
\text { Late Islamic } \\
\text { period/brwon }\end{array}$ & 18 \\
\hline $\begin{array}{c}\text { Major phases: Calcite, Quartz } \\
\alpha \\
\text { Minor phases: Feldspar, } \\
\text { Hematite }\end{array}$ & $\begin{array}{c}\text { مفرغ متأخر /نخودى } \\
\text { Late bronze } \\
\text { age/buff }\end{array}$ & 40 & $\begin{array}{l}\text { Major phases: Quartz } \alpha \text {, } \\
\text { Minor phases: Calcite, Clay } \\
\text { mineral, Hematite, } \\
\text { Pyroxene }\end{array}$ & $\begin{array}{c}\text { متأخر /قهواماى } \\
\text { Late Islamic } \\
\text { period/brwon }\end{array}$ & 19 \\
\hline $\begin{array}{c}\text { Major phases: Quartz } \alpha \\
\text { Minor phases Calcite, } \\
\text { Pyroxene, Feldspar, Clay } \\
\text { mineral, Hematite }\left(\alpha-\mathrm{Fe}_{2} \mathrm{O}_{3}\right)\end{array}$ & $\begin{array}{c}\text { مفرغ متأخر/نخودى } \\
\text { Late bronze } \\
\text { age/buff }\end{array}$ & 41 & $\begin{array}{l}\text { Major phases: Calcite } \\
\text { Minor phases: Quartz } \alpha \text {, } \\
\text { Feldspar, Hematite }\end{array}$ & $\begin{array}{l}\text { متأخر /قهوهاى } \\
\text { Late Islamic } \\
\text { period/brwon }\end{array}$ & 20 \\
\hline $\begin{array}{l}\text { Major phases: Calcite, Quartz } \\
\alpha \\
\text { Minor phases: Feldspar, Clay } \\
\text { mineral, Hematite }\end{array}$ & $\begin{array}{l}\text { عصر آهن I/نخودى I/buff } \\
\text { Iron Age I/buff }\end{array}$ & 42 & $\begin{array}{c}\text { Major phases: Calcite } \\
\text { Minor phases: Quartz, } \\
\text { Magnetite }\end{array}$ & $\begin{array}{c}\text { متأخر /قهواماى } \\
\text { Late Islamic } \\
\text { period/brwon }\end{array}$ & 21 \\
\hline
\end{tabular}

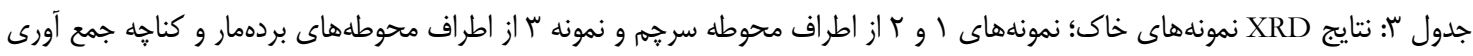

$$
\text { شده است. }
$$

Table 3: XRD results of soil samples. Samples 1 and 2 collected from the area in the vicinity of Sarcham site; sample 3 from the area that surrounds the Bardeh Mar and Kenacheh sites.

\begin{tabular}{|c|c|c|c|}
\hline $\begin{array}{l}\text { نتايج XRD اسامى به ترتيب فراوانى است. } \\
\text { XRD result is in order of abundance. }\end{array}$ & $\begin{array}{l}\text { موقعيت نمونههاى خاك } \\
\text { Soil samples position }\end{array}$ & $\begin{array}{l}\text { نو نو نو } \\
\text { Sample } \\
\text { type. }\end{array}$ & $\begin{array}{l}\text { شماره نمونه } \\
\text { Sample Nr. }\end{array}$ \\
\hline $\begin{array}{c}\text { Calcite } \\
\text { Quartz (low) }\end{array}$ & 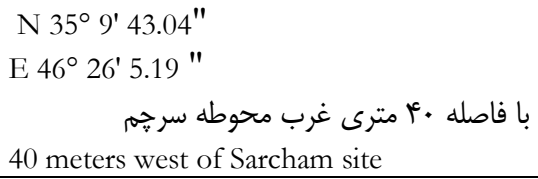 & 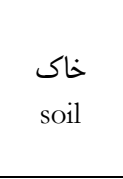 & 1 \\
\hline $\begin{array}{l}\text { Calcite } \\
\text { Quartz }\end{array}$ & 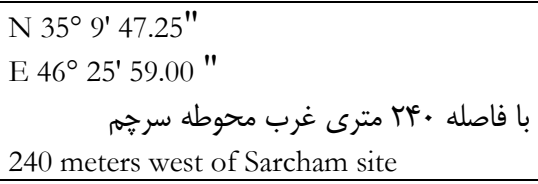 & 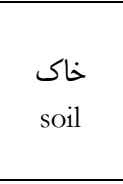 & 2 \\
\hline $\begin{array}{l}\text { Calcite } \\
\text { Quartz }\end{array}$ & 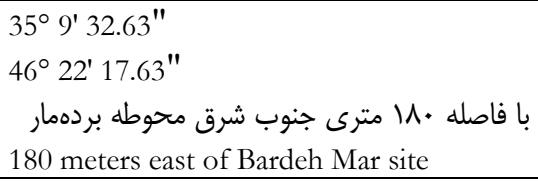 & $\begin{array}{l}\text { خاك } \\
\text { soil }\end{array}$ & 3 \\
\hline
\end{tabular}


خاكها و

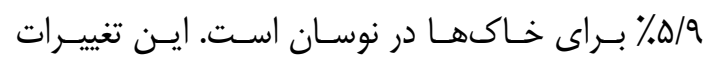

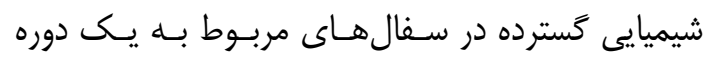

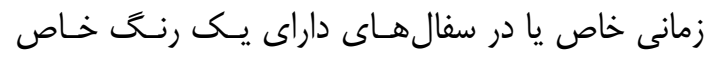

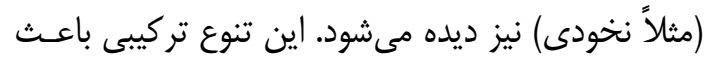

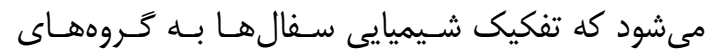

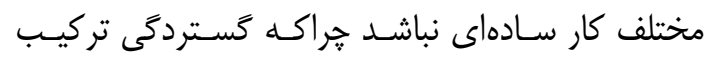

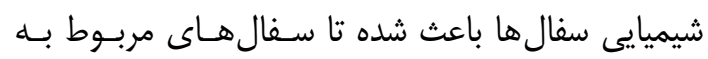

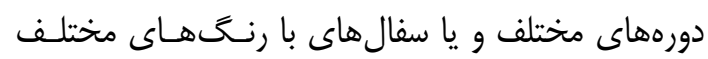

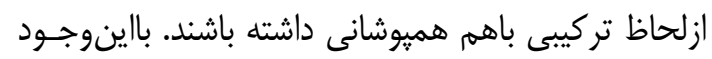

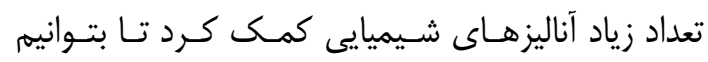
ارزيابى مناسبى را از سفال ها ارائه دهيم.

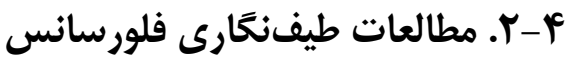 \\ يرتوايكس (XRF)}

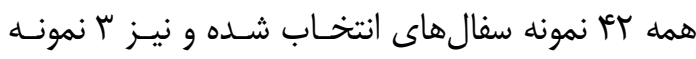

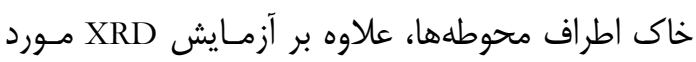

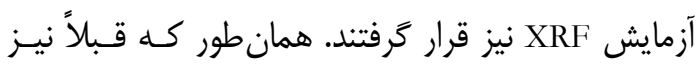

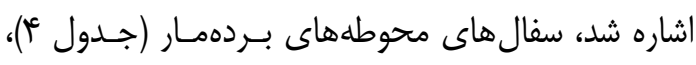

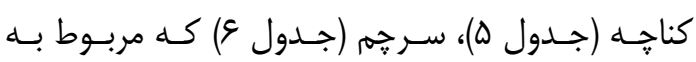

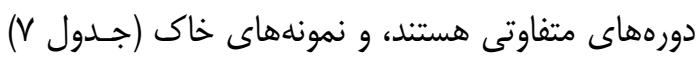

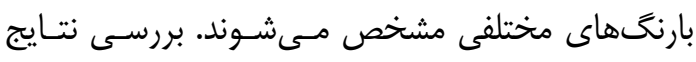

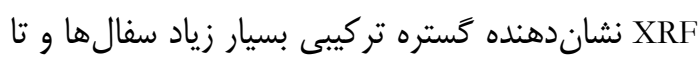

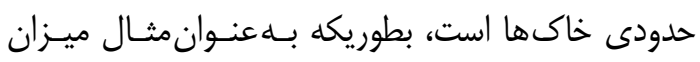

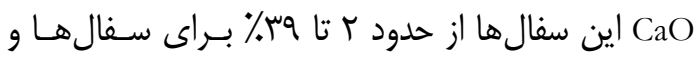

جدول t: نتايج آناليز XRF سفال هاى بردمار

Table 4: Results of XRF analysis of Bardeh Mar site

\begin{tabular}{|c|l|l|l|l|l|l|l|l|l|l|l|l|l|l|}
\hline sample wt $\%$ & 1 & 2 & 3 & 4 & 5 & 6 & 7 & 8 & 9 & 10 & 11 & 12 & 13 & 14 \\
\hline $\mathrm{SiO}_{2}$ & 20.9 & 29.2 & 41.8 & 26.4 & 30.2 & 47.7 & 19.0 & 58.4 & 20.3 & 28.3 & 29.4 & 25.1 & 46.5 & 47.5 \\
\hline $\mathrm{TiO}_{2}$ & 0.96 & 1.20 & 0.81 & 0.80 & 0.63 & 0.97 & 0.91 & 0.57 & 0.47 & 0.77 & 0.63 & 0.55 & 0.65 & 0.77 \\
\hline $\mathrm{Al}_{2} \mathrm{O}_{3}$ & 6.4 & 8.9 & 12.4 & 8.2 & 9.3 & 13.9 & 6.2 & 18.3 & 7.3 & 8.5 & 9.9 & 9.2 & 13.5 & 14.2 \\
\hline $\mathrm{Fe}_{2} \mathrm{O}_{3}$ & 5.40 & 7.30 & 6.90 & 5.30 & 5.70 & 7.40 & 2.40 & 6.50 & 4.00 & 4.90 & 5.20 & 4.90 & 6.20 & 7.80 \\
\hline $\mathrm{MnO}$ & 0.02 & 0.03 & 0.03 & 0.02 & 0.02 & 0.03 & & 0.02 & 0.02 & 0.02 & 0.02 & 0.02 & 0.02 & 0.04 \\
\hline $\mathrm{MgO}$ & 1.30 & 1.70 & 2.50 & 1.80 & 2.10 & 3.00 & 1.00 & 3.80 & 1.30 & 2.00 & 2.10 & 1.60 & 3.20 & 3.20 \\
\hline $\mathrm{CaO}$ & 36.2 & 29.2 & 21.8 & 33.1 & 32.7 & 16.2 & 38.5 & 6.9 & 36.9 & 29.1 & 27.8 & 32.2 & 17.7 & 14.0 \\
\hline $\mathrm{Na}_{2} \mathrm{O}$ & & & 0.60 & & 0.12 & 0.27 & & 1.60 & & & & & 0.11 & 0.60 \\
\hline $\mathrm{K}_{2} \mathrm{O}$ & 0.01 & 0.14 & 0.28 & 0.24 & 0.19 & 0.35 & 0.15 & 0.32 & 0.13 & 0.20 & 0.20 & 0.14 & 0.45 & 0.44 \\
\hline $\mathrm{P}_{2} \mathrm{O}$ & 0.42 & 0.44 & 0.66 & 0.47 & 0.27 & 0.48 & 0.53 & 0.38 & 0.34 & 0.28 & 0.63 & 0.33 & 0.49 & 1.40 \\
\hline $\mathrm{SO}$ & & & & & & & 0.12 & & & & & & & \\
\hline $\mathrm{SrO}$ & 0.02 & 0.01 & 0.02 & 0.01 & 0.01 & & 0.02 & 0.01 & & 0.01 & & & 0.01 & 0.01 \\
\hline $\mathrm{LOI}$ & 27.7 & 21.5 & 12.0 & 23.6 & 18.5 & 9.7 & 30.9 & 3.0 & 29.1 & 25.9 & 24.0 & 25.8 & 10.9 & 9.5 \\
\hline $\mathrm{sum}$ & 99.3 & 99.6 & 99.8 & 99.9 & 99.8 & 100.0 & 99.8 & 99.8 & 99.9 & 100.0 & 99.9 & 99.9 & 99.8 & 99.5 \\
\hline
\end{tabular}

جدول ه: نتايج آناليز XRF سفالهاى كناجه

Table 5: Results of XRD analysis of the Kenacheh potteries

\begin{tabular}{|l|l|l|l|l|l|l|l|l|}
\hline sample wt $\%$ & 15 & 16 & 17 & 18 & 19 & 20 & 21 & 22 \\
\hline $\mathrm{SiO}_{2}$ & 49.2 & 46.1 & 23.4 & 50.5 & 54.3 & 18.6 & 29.0 & 52.1 \\
\hline $\mathrm{TiO}_{2}$ & 0.80 & 0.97 & 0.52 & 0.76 & 0.87 & 0.83 & 1.20 & 0.95 \\
\hline $\mathrm{Al}_{2} \mathrm{O}_{3}$ & 14.1 & 13.8 & 8.9 & 14.2 & 14.9 & 6.4 & 8.9 & 14.6 \\
\hline $\mathrm{Fe}_{2} \mathrm{O}_{3}$ & 7.30 & 8.10 & 4.50 & 7.00 & 7.80 & 4.30 & 6.80 & 7.50 \\
\hline $\mathrm{MnO}$ & 0.03 & 0.06 & 0.02 & 0.03 & 0.03 & 0.01 & 0.03 & 0.03 \\
\hline $\mathrm{MgO}$ & 3.20 & 2.70 & 1.60 & 3.20 & 3.30 & 1.60 & 2.10 & 3.30 \\
\hline $\mathrm{CaO}$ & 15.1 & 15.6 & 33.2 & 12.5 & 9.8 & 37.0 & 28.1 & 11.9 \\
\hline $\mathrm{Na} 2 \mathrm{O}$ & 0.46 & 0.45 & 0.12 & 0.46 & 0.59 & 0.02 & 0.11 & 0.61 \\
\hline $\mathrm{K}_{2} \mathrm{O}$ & 0.35 & 0.33 & 0.28 & 0.48 & 0.42 & 0.26 & 0.38 & 0.43 \\
\hline $\mathrm{P}_{2} \mathrm{O}$ & 0.39 & 0.32 & 0.27 & 0.33 & 0.88 & 0.24 & 0.64 & 0.78 \\
\hline $\mathrm{SO}$ & & & & & & & & \\
\hline $\mathrm{SrO}$ & & 0.01 & & & & & 0.02 & 0.01 \\
\hline $\mathrm{LOI}$ & 8.9 & 11.3 & 27.2 & 10.3 & 6.9 & 30.6 & 22.3 & 7.6 \\
\hline sum & 99.8 & 99.7 & 100.0 & 99.8 & 99.8 & 99.9 & 99.5 & 99.8 \\
\hline
\end{tabular}


جدول و: نتايج آناليز XRF سفالمهاى سرجم

Table 6: The results of XRF analysis of the Sarcham potteries

\begin{tabular}{|l|l|l|l|l|l|l|l|l|l|l|l|l|l|l|l|l|l|l|l|l|}
\hline sample wt $\%$ & 23 & 24 & 25 & 26 & 27 & 28 & 29 & 30 & 31 & 32 & 33 & 34 & 35 & 36 & 37 & 38 & 39 & 40 & 41 & 42 \\
\hline $\mathrm{SiO}_{2}$ & 54.9 & 50.5 & 34.2 & 37.8 & 57.8 & 60.5 & 47.3 & 64.7 & 39.6 & 58.5 & 49.6 & 64.2 & 57.0 & 54.9 & 40.1 & 55.3 & 30.4 & 35.8 & 51.0 & 34.5 \\
\hline $\mathrm{TiO}_{2}$ & 0.89 & 0.77 & 0.90 & 0.79 & 0.89 & 0.75 & 0.64 & 0.80 & 0.77 & 0.95 & 0.68 & 0.76 & 0.77 & 0.71 & 0.75 & 0.79 & 0.80 & 0.88 & 0.71 & 0.82 \\
\hline $\mathrm{Al}_{2} \mathrm{O}_{3}$ & 17.4 & 15.0 & 10.9 & 12.2 & 17.5 & 18.5 & 14.4 & 18.4 & 12.7 & 16.7 & 15.1 & 18.5 & 16.8 & 16.1 & 12.1 & 16.3 & 9.3 & 10.7 & 15.3 & 10.2 \\
\hline $\mathrm{Fe}_{2} \mathrm{O}_{3}$ & 8.80 & 7.20 & 6.80 & 6.70 & 8.60 & 7.80 & 6.30 & 7.90 & 6.60 & 9.10 & 6.90 & 7.90 & 8.60 & 6.90 & 6.50 & 7.80 & 6.10 & 6.30 & 7.10 & 6.20 \\
\hline $\mathrm{MnO}$ & 0.02 & 0.03 & 0.02 & 0.02 & 0.03 & 0.03 & 0.02 & 0.03 & 0.03 & 0.04 & 0.02 & 0.03 & 0.04 & 0.02 & 0.03 & 0.03 & 0.02 & 0.02 & 0.03 & 0.02 \\
\hline $\mathrm{MgO}$ & 4.60 & 2.70 & 2.10 & 2.20 & 4.60 & 2.60 & 2.70 & 3.50 & 2.40 & 4.10 & 2.60 & 2.70 & 5.30 & 3.30 & 2.50 & 3.30 & 1.60 & 1.80 & 2.30 & 2.20 \\
\hline $\mathrm{CaO}$ & 7.9 & 13.4 & 23.3 & 22.1 & 6.8 & 2.9 & 13.4 & 1.8 & 19.0 & 7.5 & 13.8 & 2.1 & 5.6 & 11.5 & 20.6 & 8.5 & 30.3 & 25.5 & 12.9 & 28.0 \\
\hline $\mathrm{Na}_{2} \mathrm{O}$ & 0.72 & 0.49 & 0.05 & 0.07 & 0.80 & 0.20 & 0.05 & 0.33 & & 0.86 & 0.08 & 0.12 & 0.39 & 0.26 & 0.09 & 0.19 & & & 0.14 & \\
\hline $\mathrm{K}_{2} \mathrm{O}$ & 0.26 & 0.37 & 0.26 & 0.21 & 0.30 & 0.42 & 0.36 & 0.46 & 0.26 & 0.30 & 0.39 & 0.50 & 0.32 & 0.46 & 0.26 & 0.38 & 0.18 & 0.22 & 0.40 & 0.21 \\
\hline $\mathrm{P}_{2} \mathrm{O}_{5}$ & 0.48 & 0.69 & 0.53 & 0.51 & 0.48 & 0.48 & 0.40 & 0.27 & 0.37 & 0.62 & 0.65 & 0.35 & 0.36 & 0.94 & 0.41 & 0.65 & 0.53 & 0.57 & 0.57 & 0.55 \\
\hline $\mathrm{SO}_{3}$ & & & & & & & & & & & & & & & & & & 0.01 & & \\
\hline $\mathrm{SrO}$ & & 0.01 & 0.01 & 0.01 & 0.01 & 0.01 & & 0.01 & 0.01 & 0.01 & 0.01 & 0.01 & 0.01 & 0.02 & 0.02 & 0.01 & 0.01 & 0.02 & 0.01 & 0.02 \\
\hline $\mathrm{LOI}$ & 3.8 & 8.6 & 20.8 & 17.4 & 2.0 & 5.6 & 14.4 & 1.7 & 18.0 & 1.1 & 10.0 & 2.6 & 4.4 & 4.7 & 16.5 & 6.6 & 20.7 & 18.0 & 9.5 & 17.1 \\
\hline $\mathrm{sum}$ & 99.8 & 99.8 & 99.8 & 100.0 & 99.8 & 99.8 & 99.9 & 99.9 & 99.7 & 99.8 & 99.8 & 99.8 & 99.6 & 99.8 & 99.9 & 99.9 & 99.9 & 99.8 & 99.9 & 99.8 \\
\hline
\end{tabular}

جدول \: نتايج آناليز XRF نمونههاى خاك XRF

Table 7: The results of XRF analysis of the soil samples

\begin{tabular}{|l|l|l|l|}
\hline sample $\mathrm{wt}^{0} \%$ & 1 & 2 & 3 \\
\hline $\mathrm{SiO}_{2}$ & 15.5 & 31.9 & 26.7 \\
\hline $\mathrm{TiO}_{2}$ & 0.65 & 0.79 & 0.62 \\
\hline $\mathrm{Al}_{2} \mathrm{O}_{3}$ & 5.5 & 10.8 & 9.8 \\
\hline $\mathrm{Fe}_{2} \mathrm{O}_{3}$ & 3.4 & 5.9 & 5.2 \\
\hline $\mathrm{MnO}$ & 0.01 & 0.022 & 0.019 \\
\hline $\mathrm{MgO}$ & 1.4 & 2.7 & 2.3 \\
\hline $\mathrm{CaO}$ & 37.8 & 21.8 & 26.7 \\
\hline $\mathrm{Na} 2 \mathrm{O}$ & 0.041 & 0.099 & 0.087 \\
\hline $\mathrm{K}_{2} \mathrm{O}$ & 0.085 & 0.21 & 0.17 \\
\hline $\mathrm{P}_{2} \mathrm{O}_{5}$ & 0.052 & 0.31 & 0.2 \\
\hline $\mathrm{SO}$ & - & - & - \\
\hline $\mathrm{SrO}$ & 0.015 & 0.011 & - \\
\hline $\mathrm{LOI}$ & 35.02 & 25.28 & 27.98 \\
\hline sum & 99.473 & 99.822 & 99.776 \\
\hline
\end{tabular}

همان طور كه در شكل V ملاحظه مسىشـود همبوشـانى

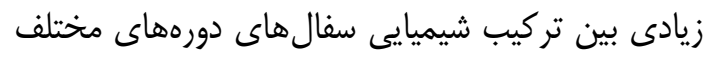
ديده مىشود و اين موضوع مىتواند، كويايى آن باشد كه

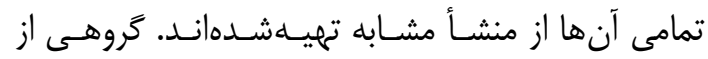

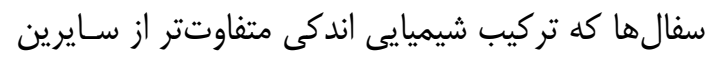
دارند سفال هاى مربوط به دوره اسلامى متـأخر هستـتند.

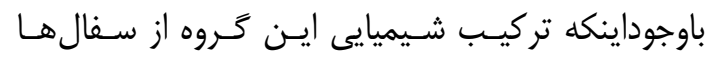

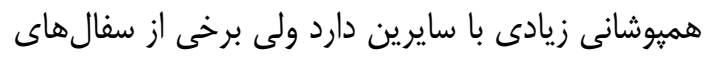

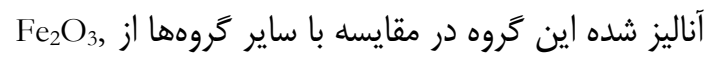

در شكل \ برخى نمودارهاى تغييرات شيميايى سفالهـا

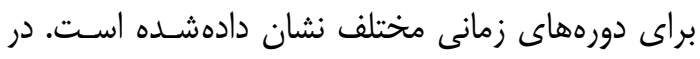

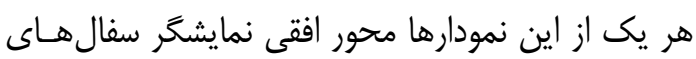
مربوط به دورههاى زمـانى مختلـف و محسور قـائم نيـز

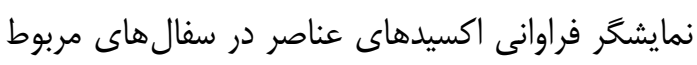

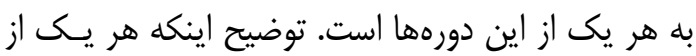

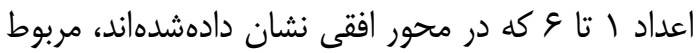
به يك دوره زمانى خاص هستند. هر يكى از اين دورههـا

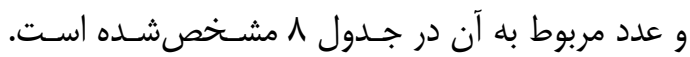

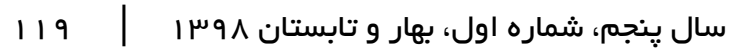


جدول ^. راهنماى اعداد نمايش دادهده در محور افقى شكل V كه مشخص مى سازد هر عدد مربوط به خه دوره زمانى است.

Table 8: The legend of the numbers in horizontal axis of figure 7 showing the periods specified by each number.

\begin{tabular}{|c|c|c|}
\hline Late Islamic period, Bardeh Mar & اسلامى متأخر، محوطه بردهمار & 1 \\
\hline Late Islamic period, Kenacheh & اسلامى متأخر، محوطه كناجه & 2 \\
\hline Parthian/Sassanian period & تاريخى & 3 \\
\hline Chalcolithic & مسسنگى & 4 \\
\hline IIron Age & عصر آهن I & 5 \\
\hline Late bronze Age & مفرغ متأخر & 6 \\
\hline
\end{tabular}
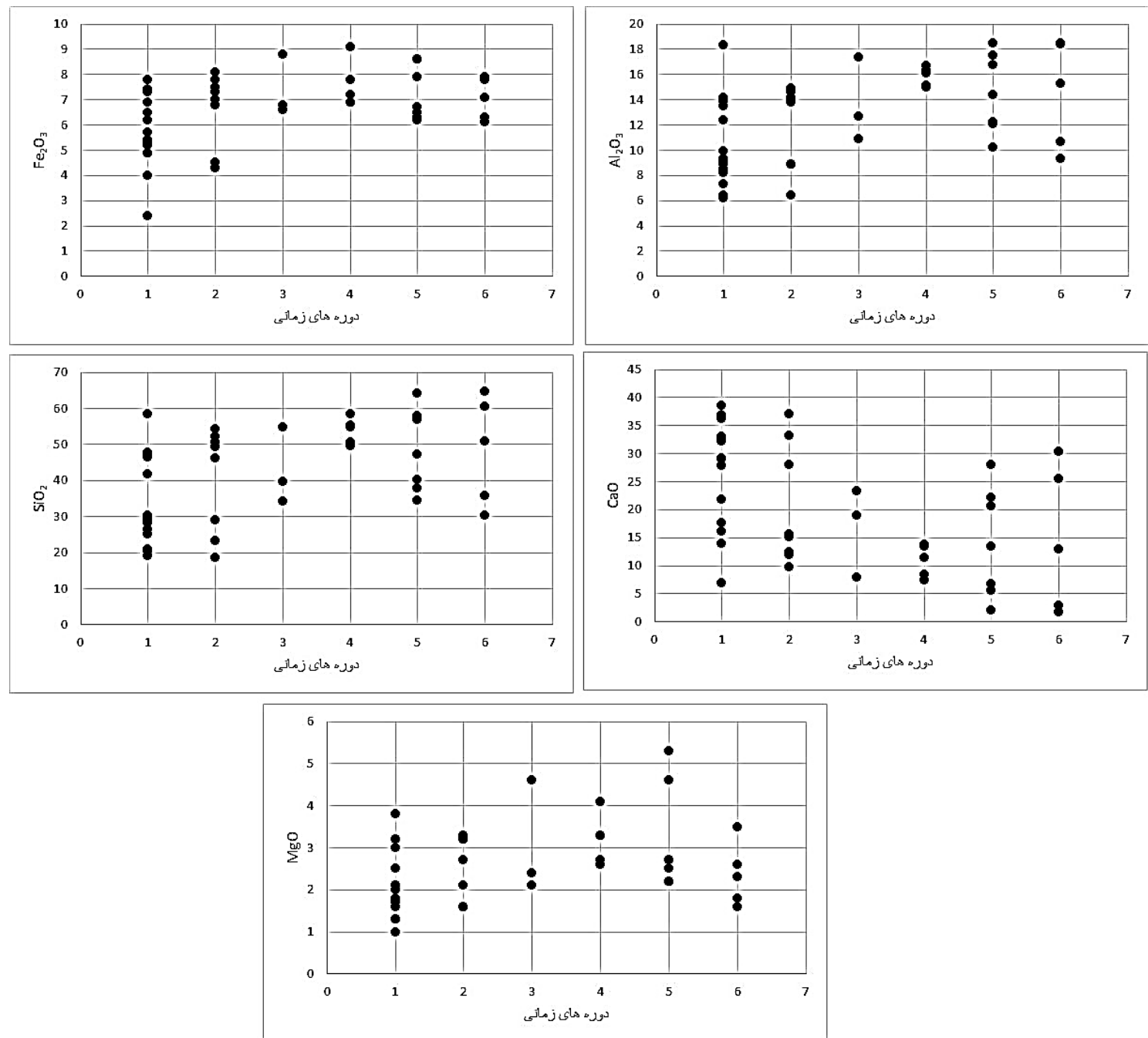

شكل V: مقايسه تر كيب شيميايى سفال هاى مربوط به دورههاى زمانى مختلف. محور قائم فراوانى اكسيدهاى عناصر را برحسب درصد وزنى و

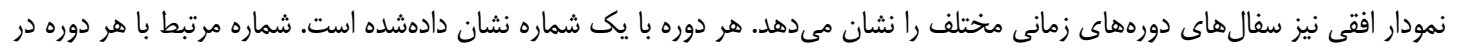

$$
\text { جدول ^ مشخص مهده است. }
$$

Fig. 7: Comparison of the chemical composition of the potteries related to different time periods. Vertical axis shows the weight percentage of the elemental oxides. Numbers in the horizontal axis correspond to different periods of time. The numbers related to each period is specified in Table 8 . 
زمينشناسى نسبت داد. مطابق نقشههاى زمـينشناسـى

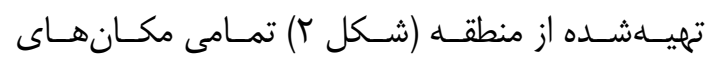

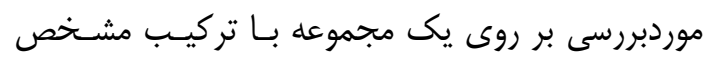

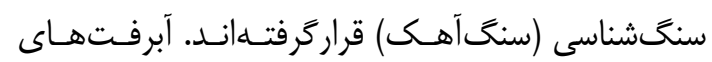

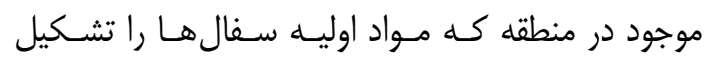

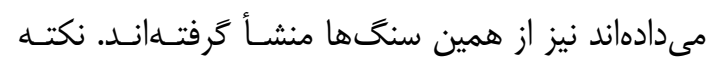
بسيار حائز اهميت اين است كه اكر نتايج آناليز خاكهـا را نيز بر روى اين نمودارها نمايش دهيم از روند سفال الها

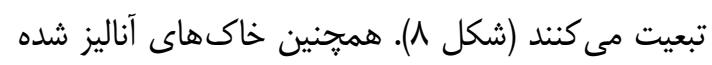

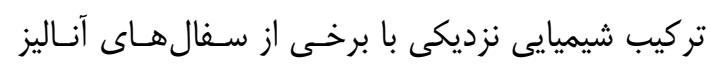

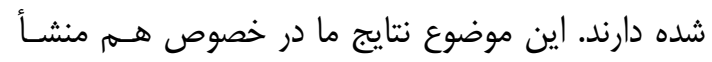

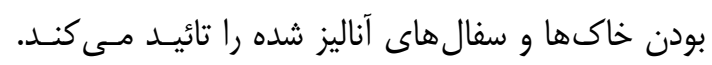

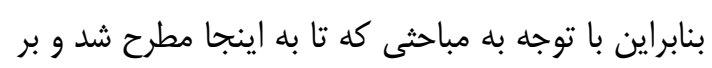

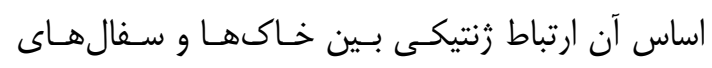

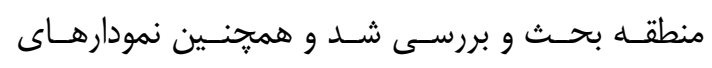

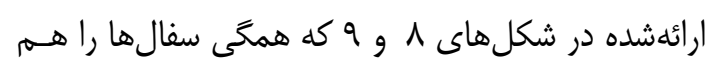

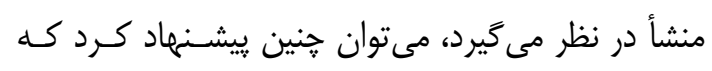

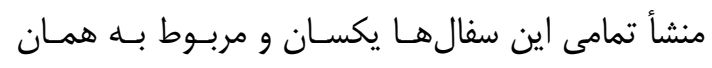

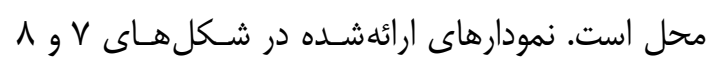

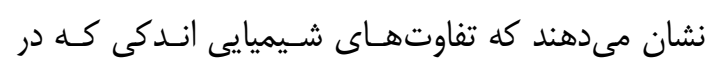

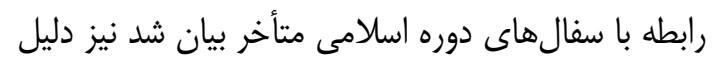

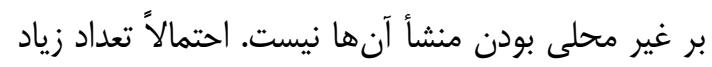

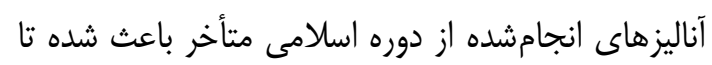

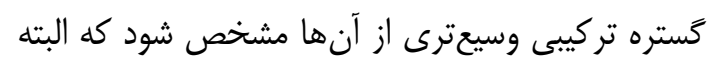

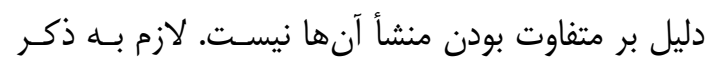

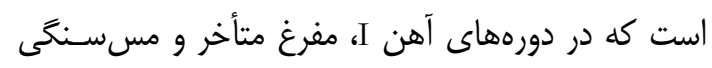

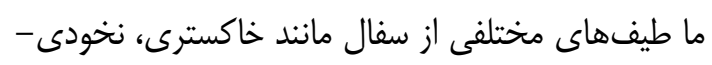

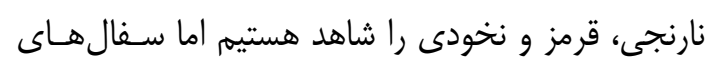

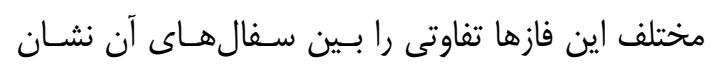

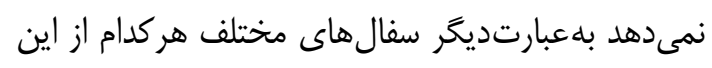

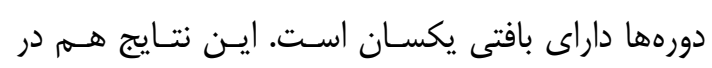
آزمايشهاى XRD و هم XRF ديده ميكان استود.

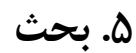

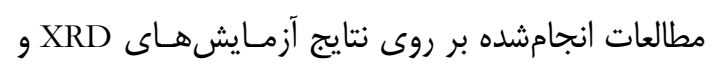

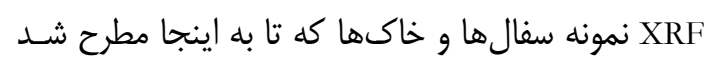

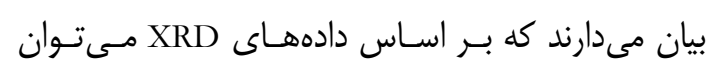

MgO, $\mathrm{Al}_{2} \mathrm{O}_{3}$

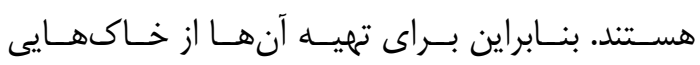

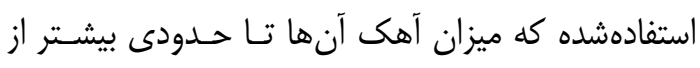

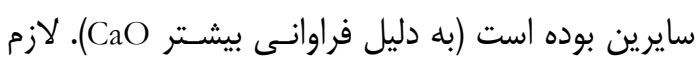
به ذكر است كه سفالهاى اسلامى متأخر كه از دو ناحيه

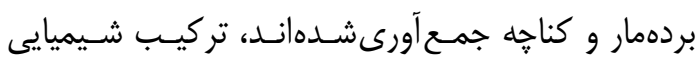
خيلى مشابه داشته و از يكديخر قابل تفكيك نيستند كـهـ

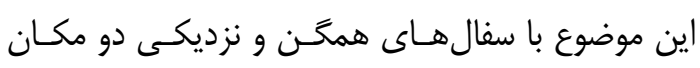

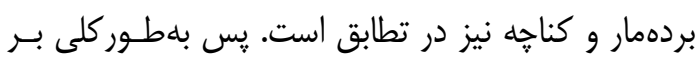

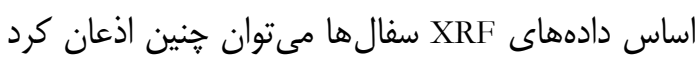
كه شباهتهاى زيادى بين تركيب سفال هاى سآ آناليز شده

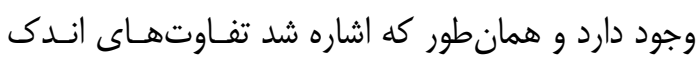

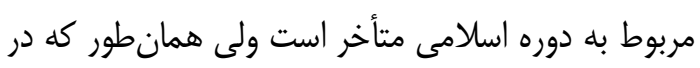
ادامه بحث خواهد شد اين تفاوت دليل بر تهيه مواد اوليه

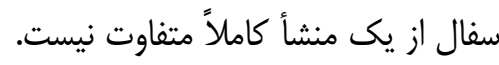
احر نتايج آناليز XRF سفال و خاك بر روى نمات نمودار

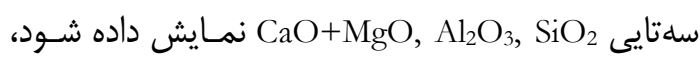

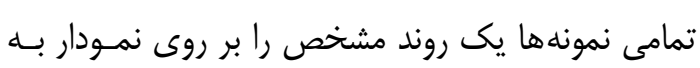

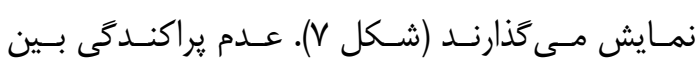
نمونه هاى مختلف كويايى وجود رابطه بين تمامى آنهـا

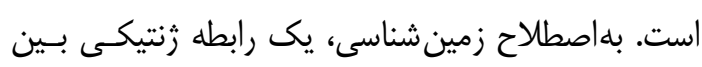

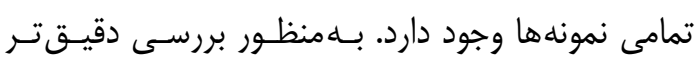

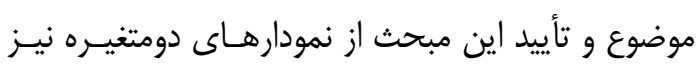

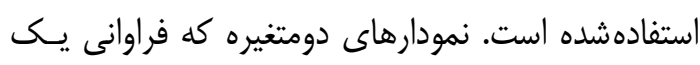

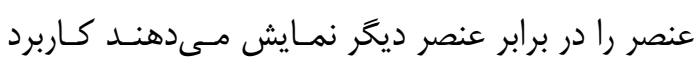

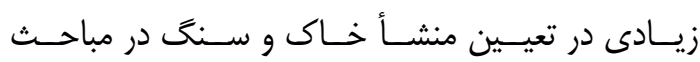

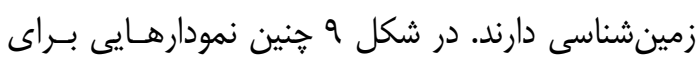

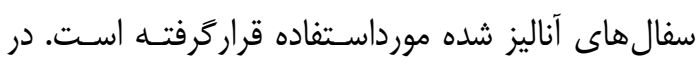
اين نمودارها تغييـرات

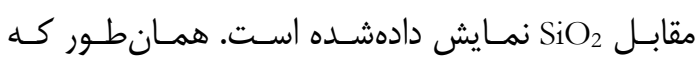

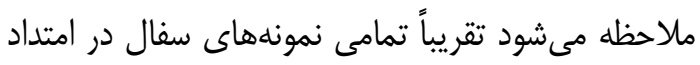

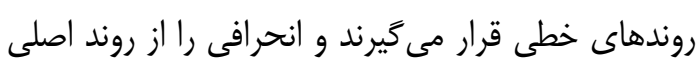

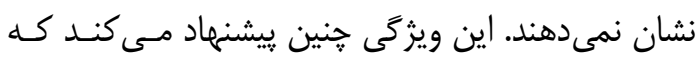

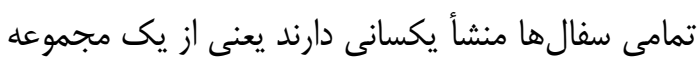

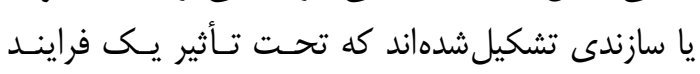

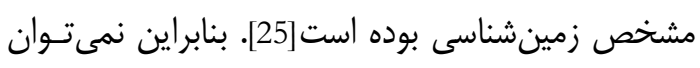

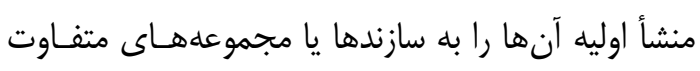




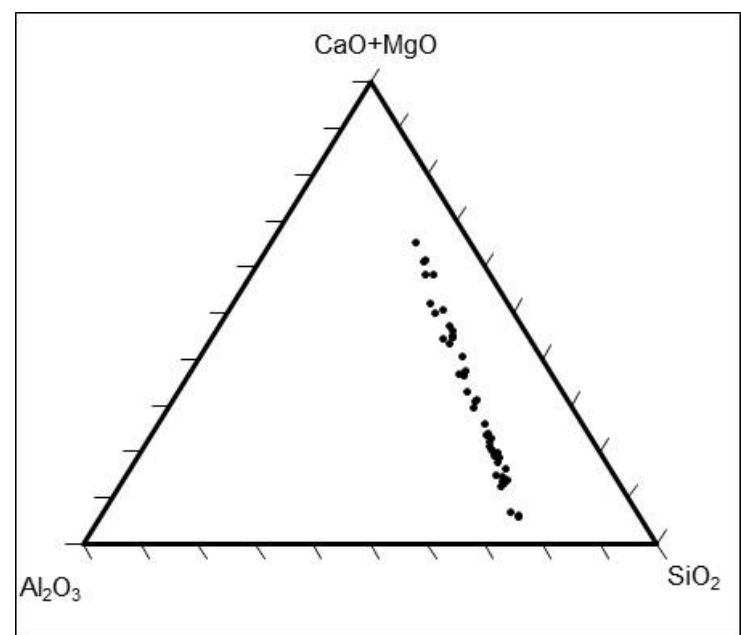

شكل م: نمايش تمامى دادهاى آناليز شده (سفال و خاك) به روش XRF بر روى نمودار سهتايى اكسيدهاى عناصر اصلى. همانطور كه

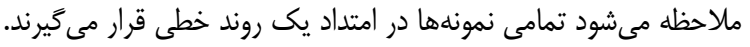

Fig. 8: Ternary diagram of major oxides in which the samples (potteries and soils) analyzed by XRF method are plotted. All the samples are showing a linear trend.

زمينشناسى نمونههاى برداشتشده بوده است كه منابع

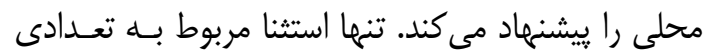

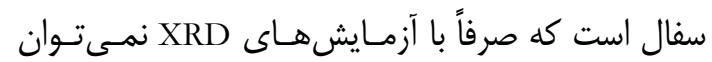

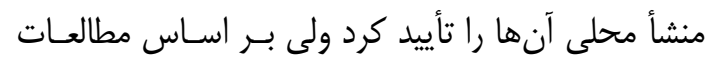
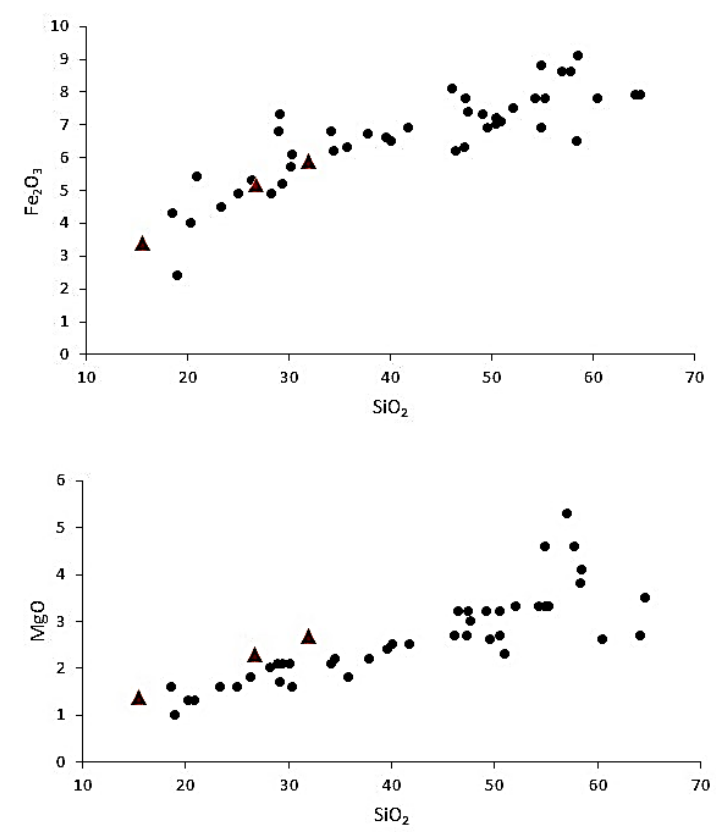

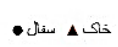

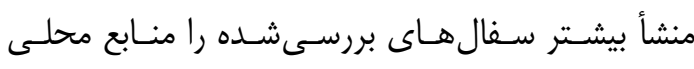
دانست. بايد به اين نكته اشاره كرد كه شناسـايى منـابع برسيع

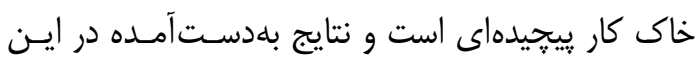

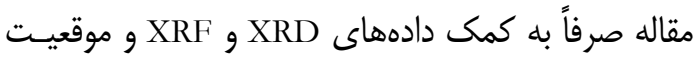
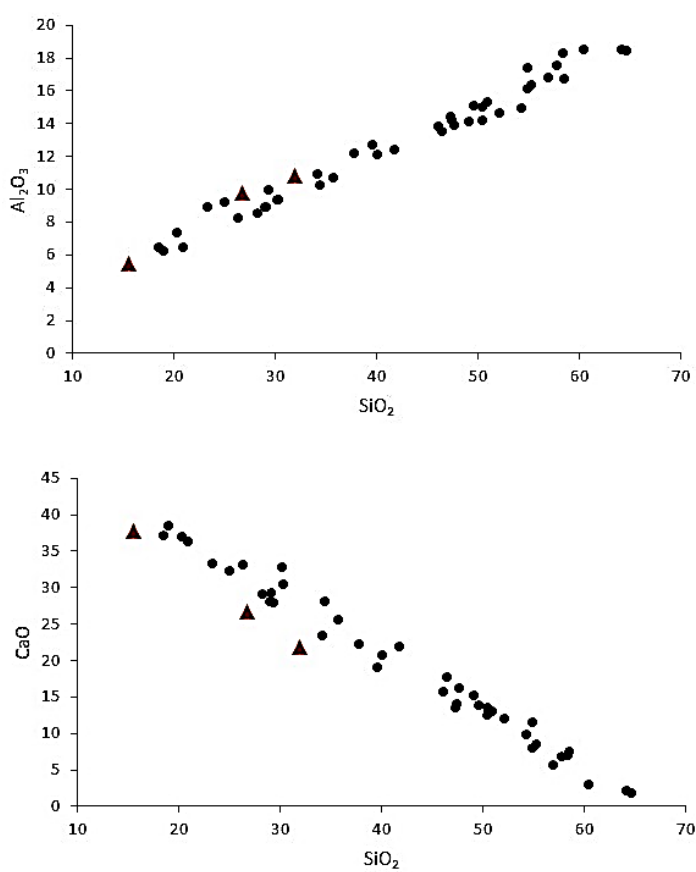

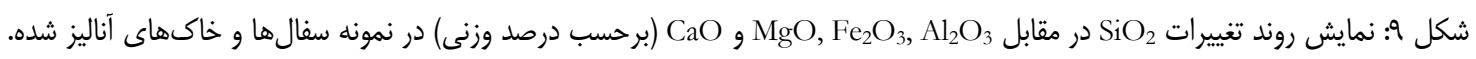

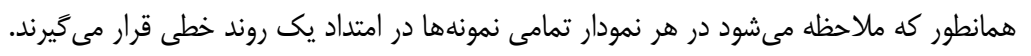

Fig. 9: $\mathrm{SiO}_{2}$ versus $\mathrm{MgO}, \mathrm{Fe}_{2} \mathrm{O}_{3}, \mathrm{Al}_{2} \mathrm{O}_{3}$ and $\mathrm{CaO}$ diagrams (weight percentage) showing the chemical variation of the potteries and soils. All the samples are showing the linear trends on each diagram. 
داراى منشأ يكسانى هستند. يكى از فرضيات مطرح در

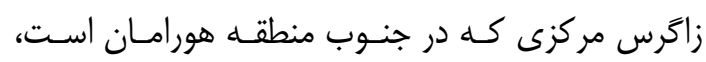

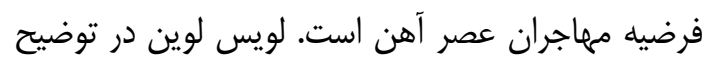

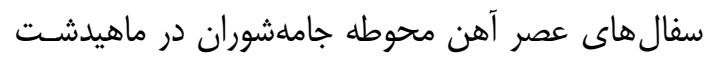

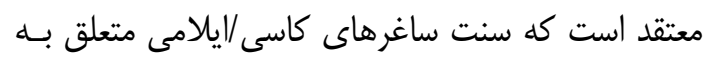

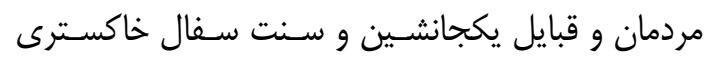

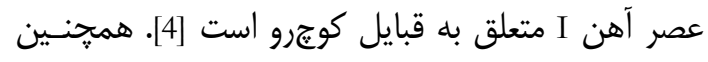

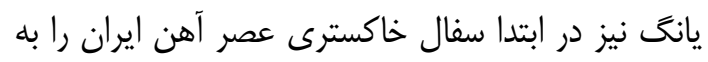
مهاجرت جمعيتها و اقوام منتسب كرده بود[5] افقى كه إنه

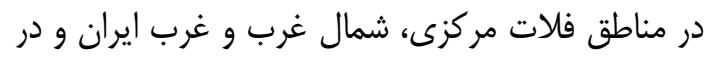

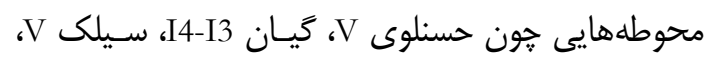

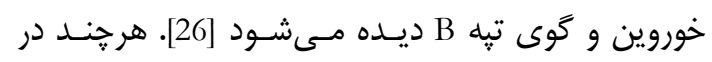

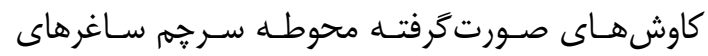

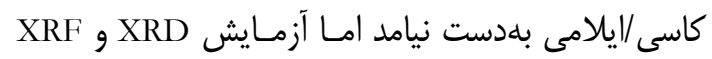

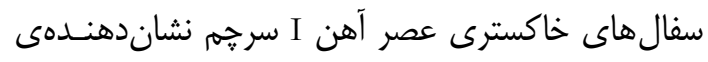

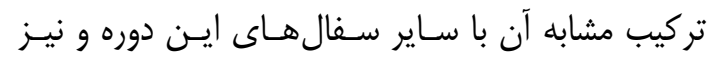

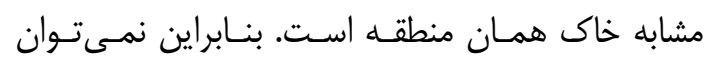

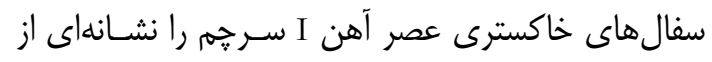

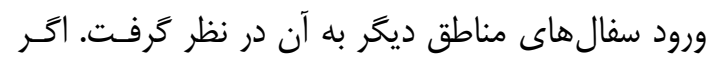
فرض لوين را هم مسله بدانيم، اقوام كوجنشين از همان

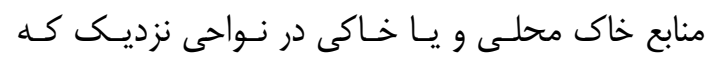

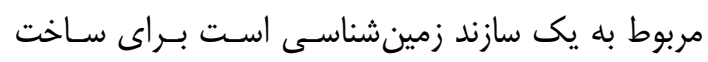

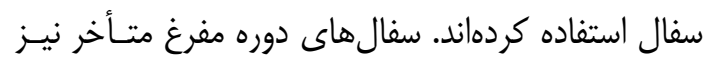
به لحاظ تنوع سفالها و نيز تركيب مواد آن مشابه سـاير دفران دورهها است و هيج كونه تفاوتى را با ساير دورهها نشان نـان

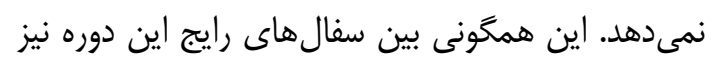

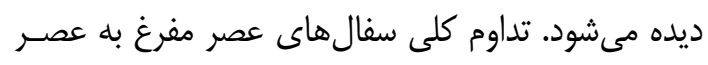

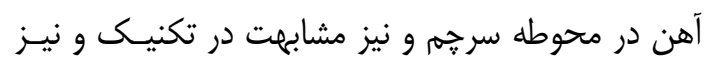
منبع خاك آنها بر تداوم سنتهاى ايـن دو دور دوره اشـاره

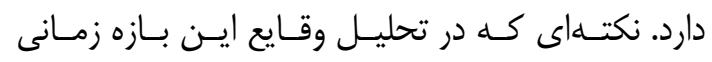

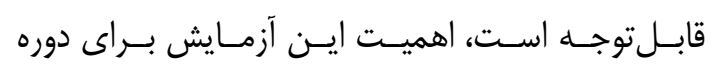

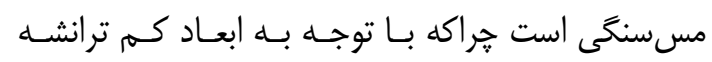

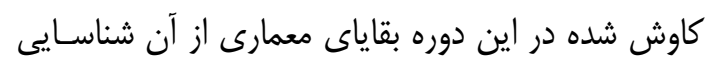

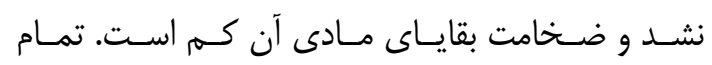
طيـفهـاى سـفالى ايـن دوره نيـز مشـابه هـمـ و سـاير

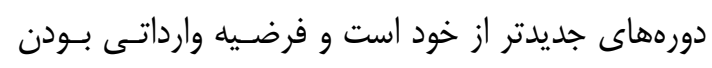
سفالهاى نخودى منقوش در ايـن دوره [26] را در ايـن فين

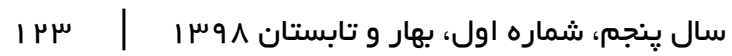

منشأ آنها نيز محلى در نظر كرفتـه مسىشـود. در XRF

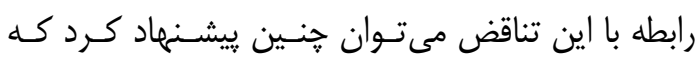

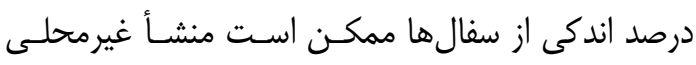

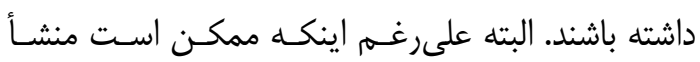

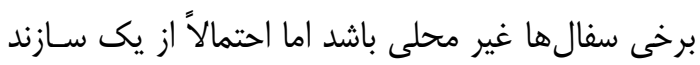
زمينشناسى مشترى كه تا نواحى دورترى امتداد داشـتهـ

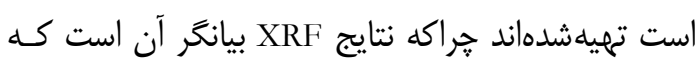

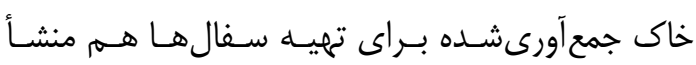

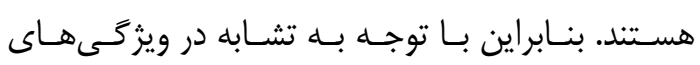
زمينشناسى مناطقى كه محوطـهـهـاى اكتشـافى در آن

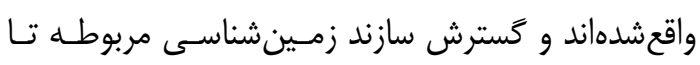

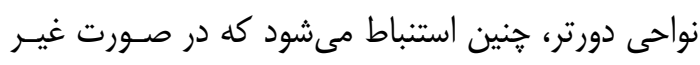

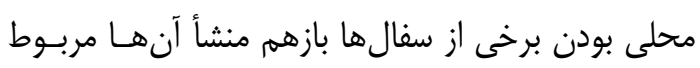

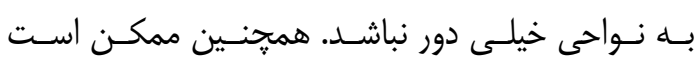

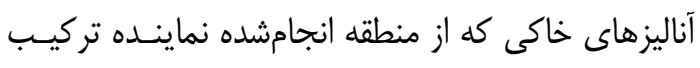

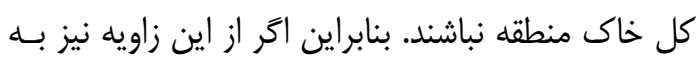

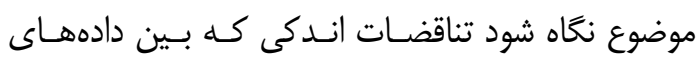

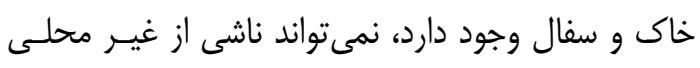
بودن منبع تأمين كننده سفال باشد. استفاده از منابع خاك محلى براى غار كناجه جالـ

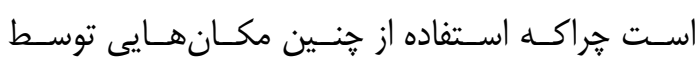

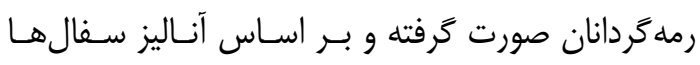

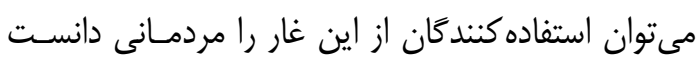

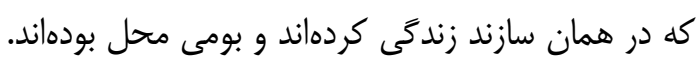

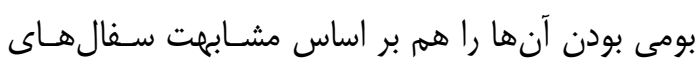

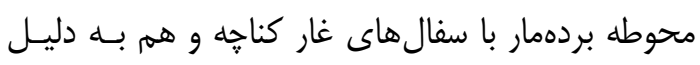

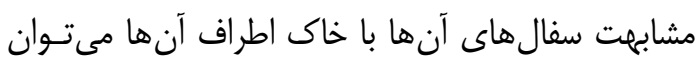

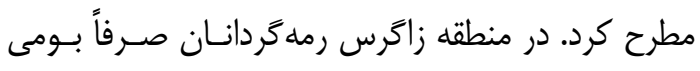

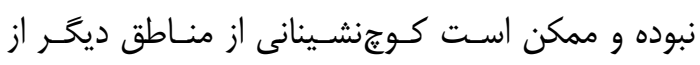

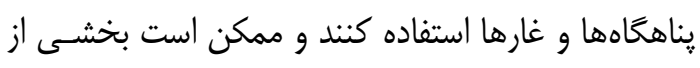

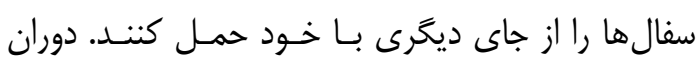

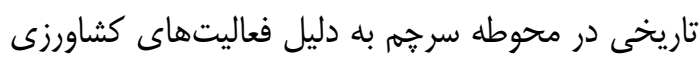

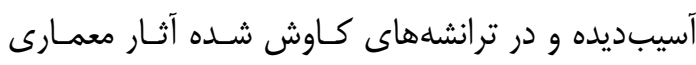
شناسايى نشد و يافتهها به سفال محدود است كه آنـاليز

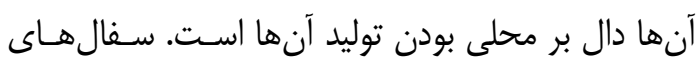
مختلف عصر آهن I محوطه سرجم كه شامل طيف كلى بلى نخودى و خاكسترى است؛ توليد محل بوده و همه آنها 
خاكسـترى و نيـز سـفال هــاى نخــودى منقــوش دوره

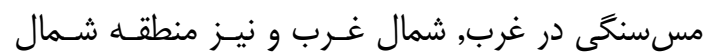

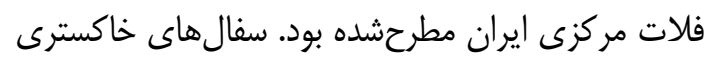

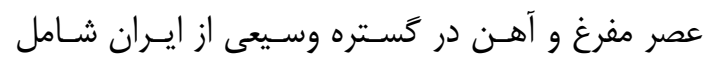

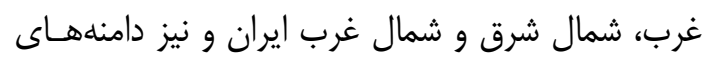

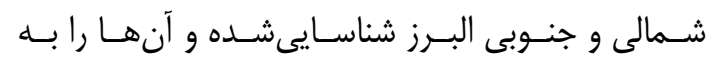

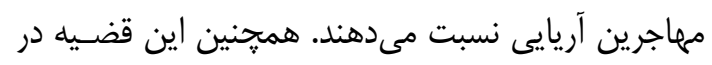

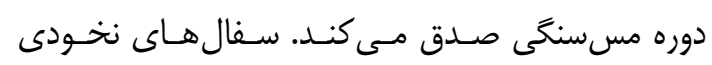

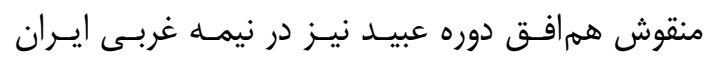

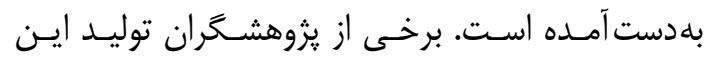

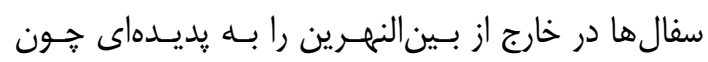

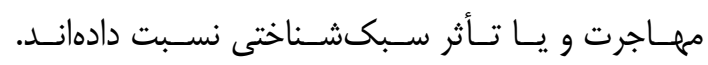

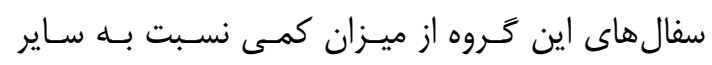

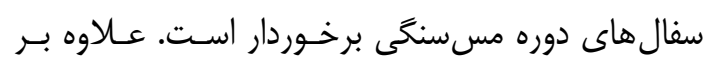

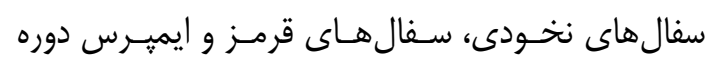

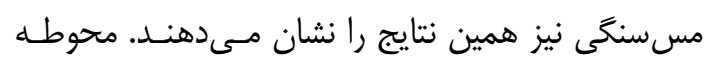

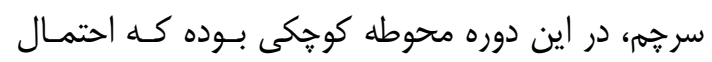

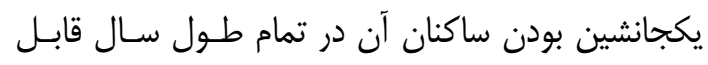
اثبات نيست و سفال هاى آن نشان مى دهد كـهـ سـاكنان

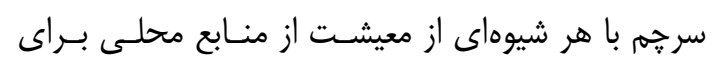

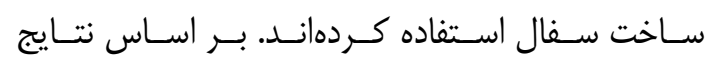

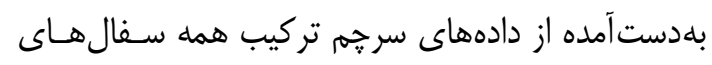

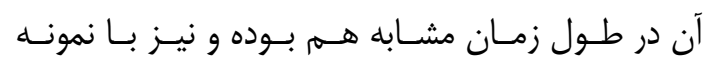

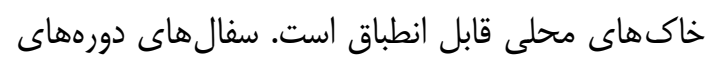

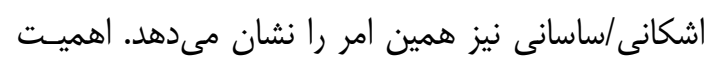

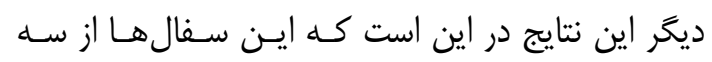

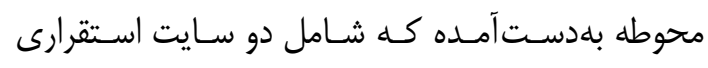

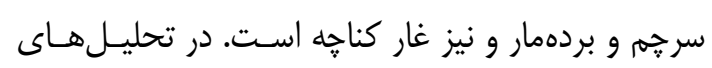

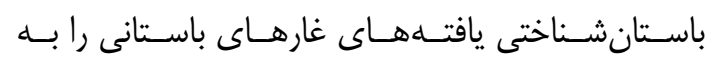

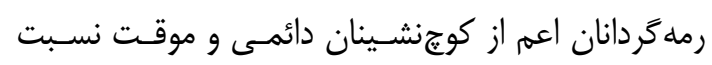

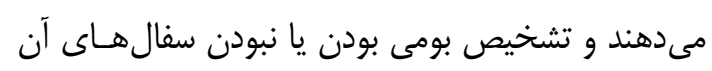

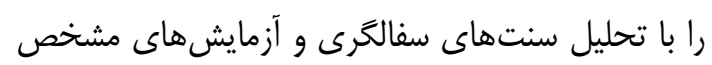

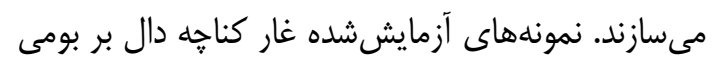

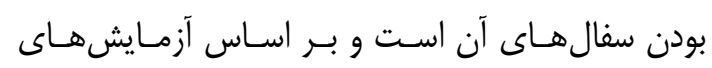

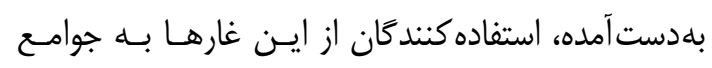

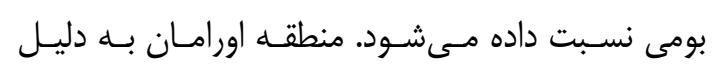

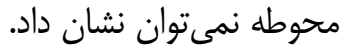

\section{و. نتيجه كيرى}

آزمايش XRD و XRF نمونه سفال هاى بهدست آمـده از

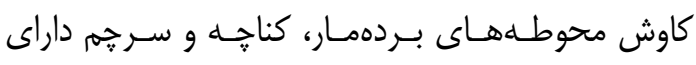

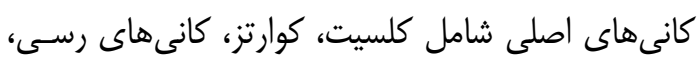

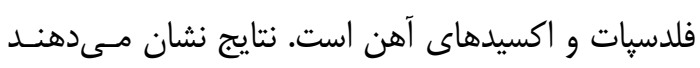

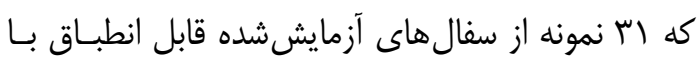

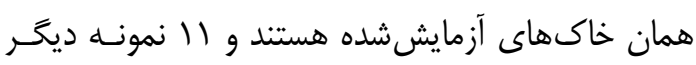

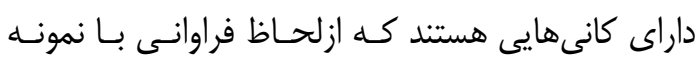
خاكهاى آزمايششده و نيز ساير نمونههاى سفال كاملاً

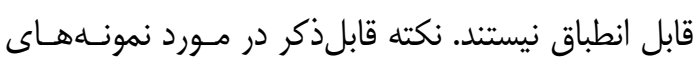

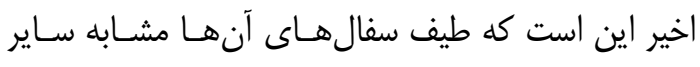

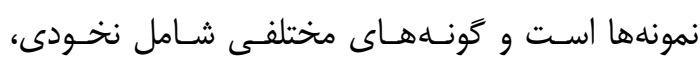

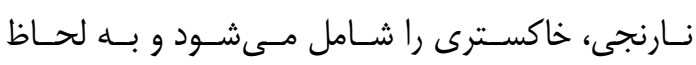
كونهشناسى، رنغ، شكل، تزيينات، و فن تفاوتى أنى با سـاير

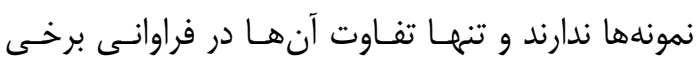

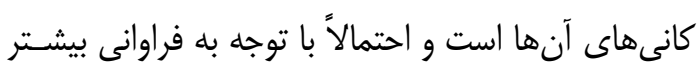

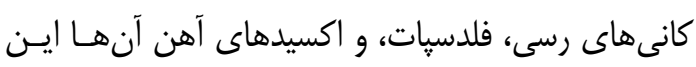

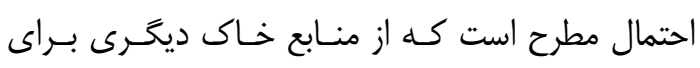

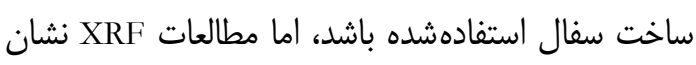

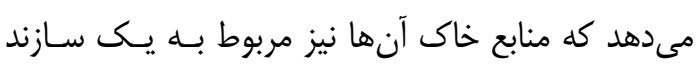

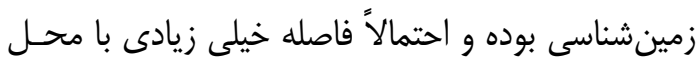

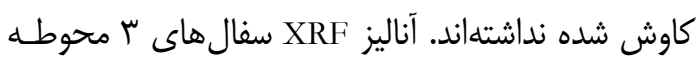

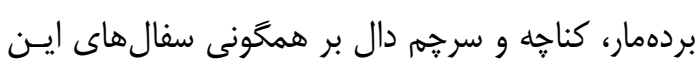

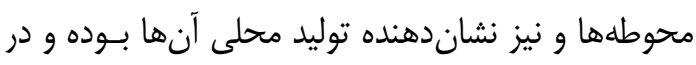

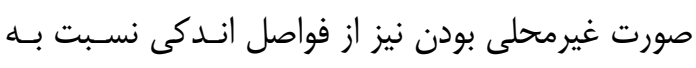

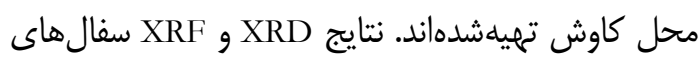

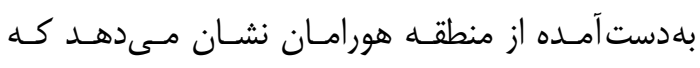

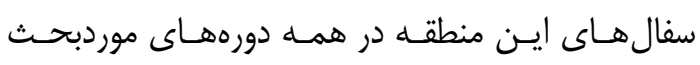

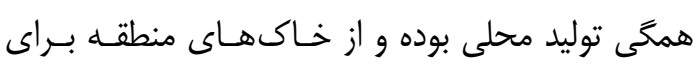

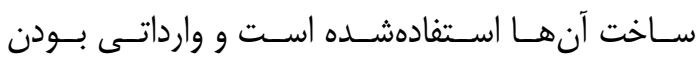

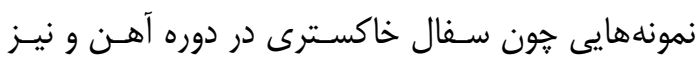
تعداد كم آنها در دوره مفرغ و اشكانى را حداقل در اين داين

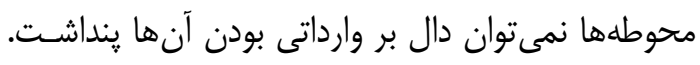

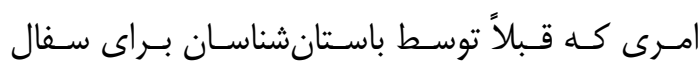




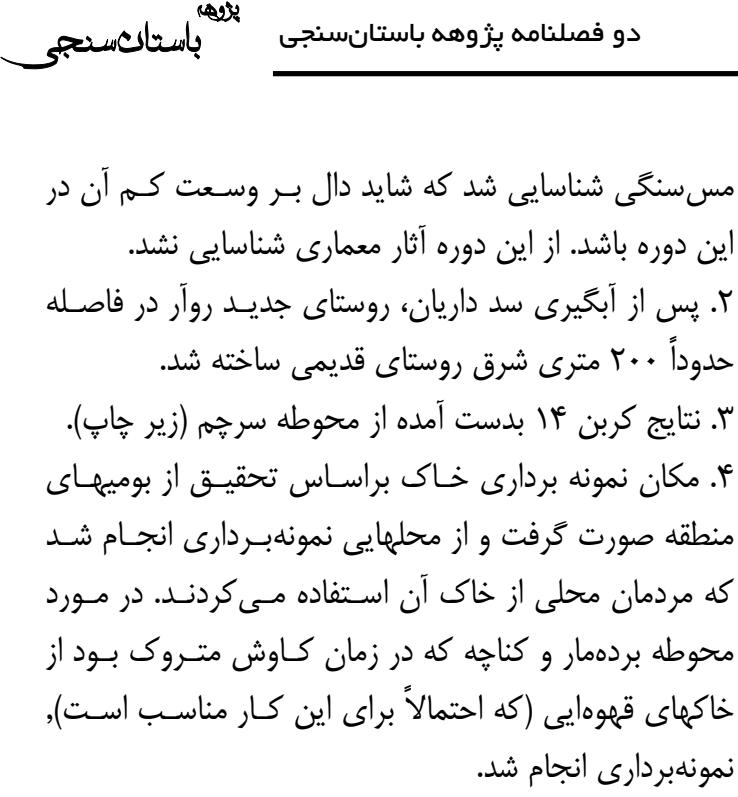

\section{References}

[1] Davidson TE, McKerrell H. Pottery analysis and Halaf period trade in the Khabur headwaters region. Iraq 1976;38:45-56.

[2] Stein G. Local identities and interaction spheres: Modeling regional variation in the Ubaid horizon. Beyond Ubaid Transform Integr Late Prehist Soc Middle East 2010:23-44.

[3] Henrickson EF. The early development of pastoralism in the Central Zagros Highlands (Luristan). Iran Antiq 1985;20:1.

[4] Levine LD. The Iron Age. Smithsonian Institution; 1987.

[5] Young TC. Early iron age Iran revisited: preliminary suggestions for the re-analysis of old constructs. J-L Huot Al 1985:36178.

[6] Goff C. Luristan in the first half of the first millennium BC. A Prelim Rep First Seas Excav Baba Jan, Assoc Surv East Pish-i Kuh, Iran 1968;6:105-34.

[7] Nogole Sadat MAA, Houshmandzadeh A. Geology map of Marivan-Baneh, Scale 1: 250000. Geol Surv Iran 1993.

[8] Frame G. The inscription of Sargon II at Tang-i Var. Orientalia 1999;68:31-57.

[9] Minns EH. Parchments of the Parthian period from Avroman in Kurdistan. J Hell Stud 1915;35:22-65.

[10] Zarei M. Tangivar inscription. Majaleye Nameh Pazhoheshgah Mirase Farhangi 2004;7:17-27. [in Persian]

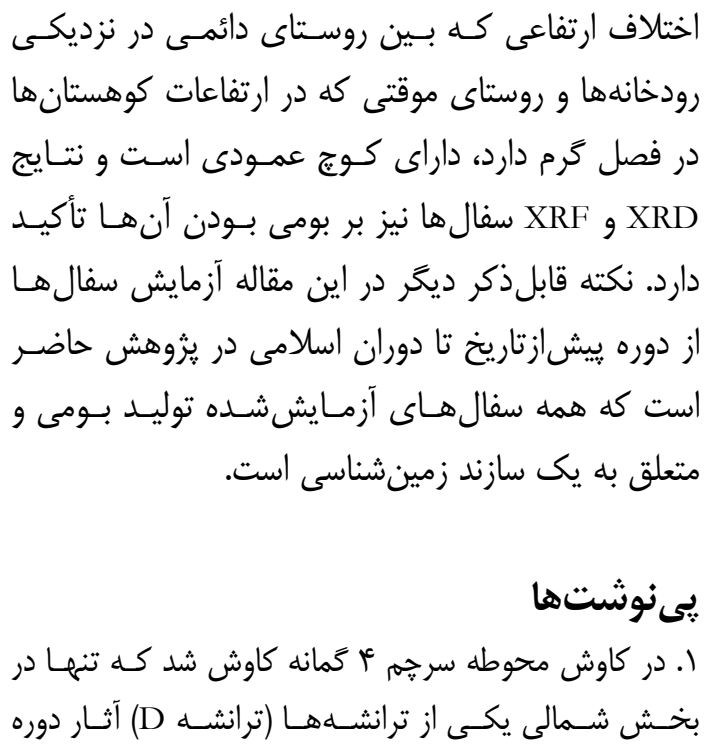

[زارعى محمدابراهيه. كتيبه و نقش برجستهـ تنكسور.

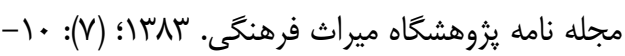
[ب.

[11] Mohammadifar Y, Motarjem A. Settlement continuity in Kurdistan. Antiquity 2008;82.

[12] Motarjem A. Excavation at pitho-burials in Zeribar Lake sphere, Marivan. 2009. [in Persian]

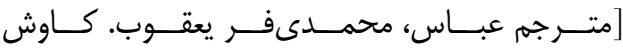

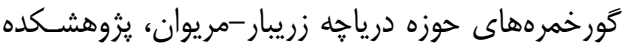

$$
\begin{aligned}
& \text { باستانشناسى؛ Mسا (كزارش منتشر نشده).] }
\end{aligned}
$$

[13] Saed Mucheshi A. Delimiting at Tepe Sarqaleh, Sarvabad. 2014. [in Persian]

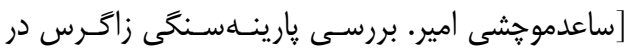

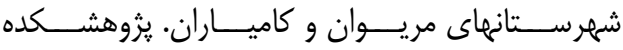

$$
\text { باستان شناسى؛ (وساس ( گزارش منتشر نشده).] }
$$

[14] Saed Mucheshi A. Paleolithic survey at Marvian and Kamyaran Counties. 2012. [in Persian]

$$
\begin{aligned}
& \text { [ساعدموجشى امير. گمانهزنى به منظور تعيين عرصه و }
\end{aligned}
$$

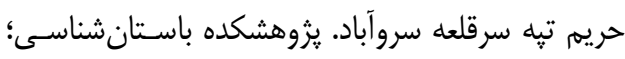

$$
\begin{aligned}
& \text { سوحسا (كزارش منتشر نشده).] }
\end{aligned}
$$

[15] Pour Bakhshandeh K. Archaeological survey in Darian Dam basin. 2012. [in Persian]

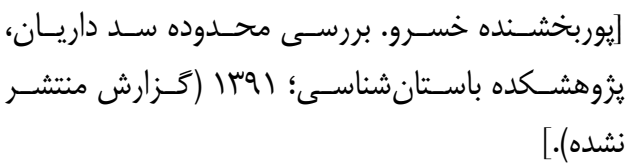

[16] Biglari F, Shidrang S, Rahmati M, 
Mashkour M, Saed Mucheshi A, Ghasimi $\mathrm{T}$, et al. Survey and salvage excavations at the Darian Dam Reservoir, Hawraman, Kurdistan and Kermanshah. Proc. 15th Annu. Archaeol. Symp. Iran, Tehran: Research Institute of Cultural Heritage \& Tourism (RICHT); 2017, p. 49-54. [in Persian]

[بيخلرى فريدون، شـيدرنت سـونيا، رحمتـى مرتضـى،

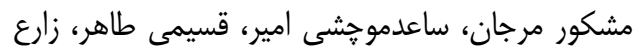

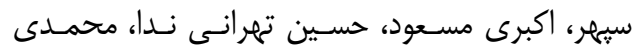

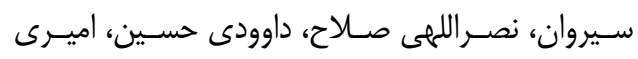

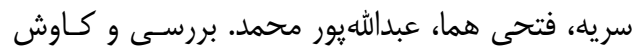
نجاتبخشى در محدوده سد داريان، هورامان، كردستان عردان

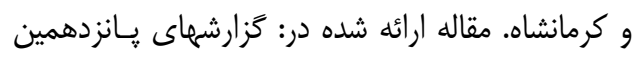

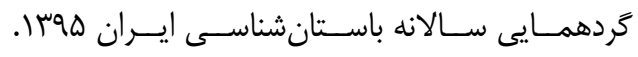

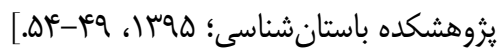

[17] Saed Mucheshi A, Nikzad M, Zamani Dadaneh M, Seif Panahi M, Mohammadi Ghasrian S, Davoudi H. Rescue excavations at Bardeh Mar site, Darian Dam area, Hawraman, Kurdistan, western Iran. Proc. 15th Annu. Symp. Iran. Archaeol., Tehran: Research Institute of Cultural Heritage \& Tourism (RICHT); 2017, p. 667-72. [in Persian]

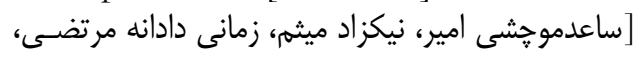
سيفيناهى مزًان، محمدى

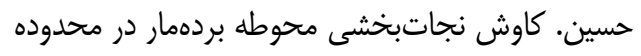

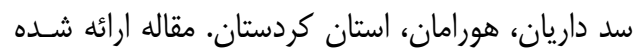

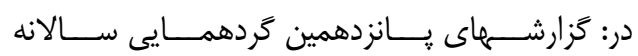

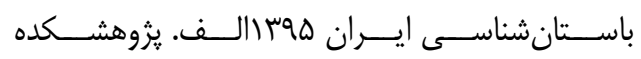

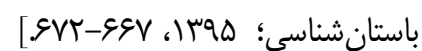

[18] Saed Mucheshi A, Mohammadi Ghasrian S, Zamani Dadaneh M, Khosravi S, Amiri S. Rescue excavations at Sarcham site, Darian Dam area, Hawraman, Kurdistan, western Iran. Proc. 15th Annu. Symp. Iran. Archaeol., Tehran: Research Institute of Cultural Heritage \& Tourism (RICHT); 2017, p. 662-6. [in Persian]

[ساعدموجشى امير، محمدىقصـريان سـيروان، زمـانى

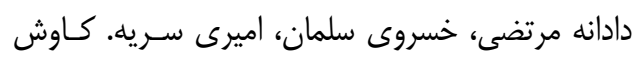

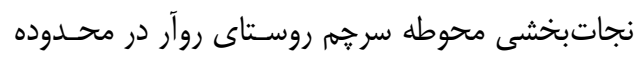

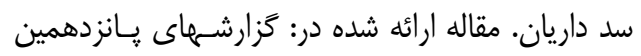

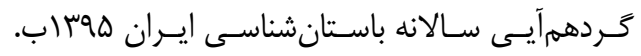

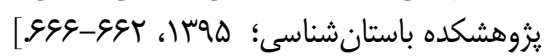

[19] Ghasimi T, Akbari M, Ghasemian M,
Ghasimi A, Ghadri M, Davoudi S, et al. Excavation at Rowar grave. Darian Dam area, Hawraman, Kurdistan, western Iran. Proc. 15th Annu. Symp. Iran. Archaeol., Tehran: Research Institute of Cultural Heritage \& Tourism (RICHT); 2017, p. 499-504. [in Persian]

[قسـيمى طـاهر، اكبـرى مسـعود، قاسـميان مجتبـى،

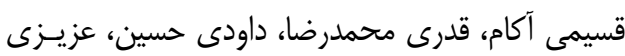

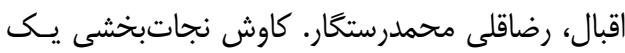

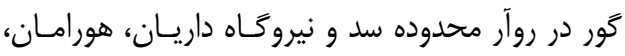

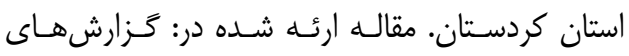

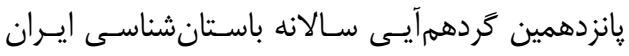

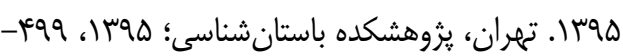

$[. \omega \cdot)^{c}$

[20] Nourzehi Z, Ajorloo B, Kasiri MB, Ebrahimi G. The archaeo-mineralogy of the Bronze Age ceramics from Kul Tepe of Ahabshir, Eastern Lake Urmia basin, Iran. JR A 2017;2:1-17. [in Persian]

[نورزهى زينب، آجورلو بهرام، باقرزاده كثيـرى مسـعود،

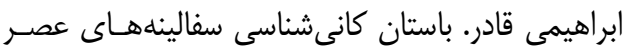

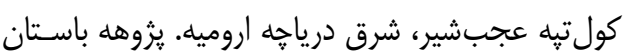

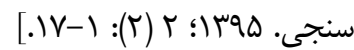

[21] Rastineh U, B. Kasiri M, Ajorloo B, Ebrahimi G. Identification the Structure of Colorants Used on the Late Bronze Age Ceramics of Eastern Lake Urmia Based on the Specimen from Kul Tepe, Ajabshir. JRA 2017;3:17-27. [in Persian] ] راستينه امالبنين. باقرزاده كثيرى مسعود، آجورلو بهرام،

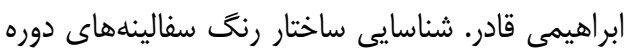

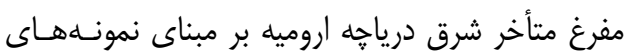

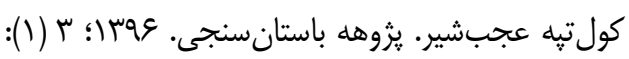

$[. r \mathrm{R}-\mathrm{IV}$

[22] Pourzarghan V, Sarhaddi-Dadian H, Ramli Z. Morphology of Ancient Potteries Using X-Ray Diffraction Analysis And X-Ray Fluorescence In Sistan Plain, Eastern Iran. Mediterr Archaeol Archaeom 2017;17:175-86.

[23] Rezaeia MH, Basafaa H, Khaka PM, Azara M. Study on Late Bronze Age Potteries of Shahrak-e Firouzeh, Neyshabur, Iran by XRD and XRF. Interdiscip Archaeol Nat Sci Archaeol 2018;IX:1-10.

[24] Luschey H. Orte in der Nachbarschaft von Bisutun, in W. Kleiss \& P. Calmeyer (ed.) Bisutun Ausgrabungen und Forschungen

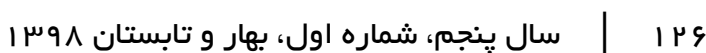


in den Jahren 1963-1967, Berlin: Teheraner Forschungen. 1996; p. 261-64.] [in Persian]

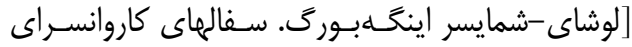

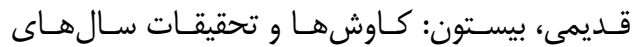

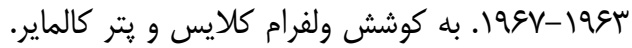

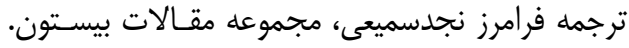

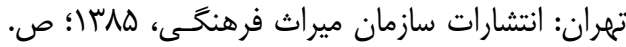
$[. r \lambda t-r \cdot r$
[25] Esmaeily D, Rahimpour-Bonab H, EsnaAshari A, Kananian A. Petrography and Geochemistry of the Jajarm Bauxite ore Deposit, Northeast Iran: Implications for Source Rock Material and Ore Genesis. Turkish J Earth Sci 2010;19:267-84.

[26] Young Jr TC. A comparative ceramic chronology for western Iran, 1500-500 BC. Iran 1965;3:53-85. 